\title{
Late Paleocene-early Eocene Tethyan carbonate platform evolution - A response to long- and short-term paleoclimatic change
}

\author{
C. Scheibner ${ }^{\mathrm{a}, *}$, R.P. Speijer ${ }^{\mathrm{b}, 1}$ \\ a Universität Bremen, FB5, P.O. Box 330440, 28334 Bremen, Germany \\ ${ }^{\mathrm{b}}$ Department of Earth and Environmental Sciences, K.U.Leuven, Celestijnenlaan 200E, 3001 Leuven, Belgium
}

\section{A R T I C L E I N F O}

\section{Article history:}

Received 23 November 2007

Accepted 24 July 2008

Available online 7 August 2008

\section{Keywords:}

Paleocene

Eocene

platform evolution

coralgal reefs

larger foraminifera

\begin{abstract}
A B S T R A C T
The early Paleogene experienced the most pronounced long-term warming trend of the Cenozoic, superimposed by transient warming events such as the Paleocene-Eocene Thermal Maximum (PETM). The consequences of climatic perturbations and associated changes on the evolution of carbonate platforms are relatively unexplored. Today, modern carbonate platforms, especially coral reefs are highly sensitive to environmental and climatic change, which raises the question how (sub)tropical reef systems of the early Paleogene reacted to gradual and sudden global warming, eutrophication of shelf areas, enhanced $\mathrm{CO}_{2}$ levels in an ocean with low $\mathrm{Mg} / \mathrm{Ca}$ ratios. The answer to this question may help to investigate the fate of modern coral reef systems in times of global warming and rising $\mathrm{CO}_{2}$ levels.

Here we present a synthesis of Tethyan carbonate platform evolution in the early Paleogene ( 59-55 Ma) concentrating on coral reefs and larger foraminifera, two important organism groups during this time interval. We discuss and evaluate the importance of the intrinsic and extrinsic factors leading to the dissimilar evolution of both groups during the early Paleogene. Detailed analyses of two carbonate platform areas at low (Egypt) and middle (Spain) paleolatitudes and comparison with faunal patterns of coeval platforms retrieved from the literature led to the distinction of three evolutionary stages in the late Paleocene to early Eocene Tethys: Stage I, late Paleocene coralgal-dominated platforms at low to middle paleolatitudes; stage II, a transitional latest Paleocene platform stage with coralgal reefs dominating at middle paleolatitudes and larger foraminifera-dominated (Miscellanea, Ranikothalia, Assilina) platforms at low paleolatitudes; and stage III, early Eocene larger foraminifera-dominated (Alveolina, Orbitolites, Nummulites) platforms at low to middle paleolatitudes. The onset of the latter prominent larger foraminifera-dominated platform correlates with the Paleocene/Eocene Thermal Maximum.

The causes for the change from coral-dominated platforms to larger foraminifera-dominated platforms are multilayered. The decline of coralgal reefs in low latitudes during platform stage II is related to overall warming, leading to sea-surface temperatures in the tropics beyond the maximum temperature range of corals. The overall low occurrence of coral reefs in the Paleogene might be related to the presence of a calcite sea. At the same time larger foraminifera started to flourish after their near extinction at the Cretaceous/ Paleogene boundary. The demise of coralgal reefs at all studied paleolatitudes in platform stage III can be founded on the effects of the PETM, resulting in short-term warming, eutrophic conditions on the shelves and acidification of the oceans, hampering the growth of aragonitic corals, while calcitic larger foraminifera flourished. In the absence of other successful carbonate-producing organisms, larger foraminifera were able to take over the role as the dominant carbonate platform inhabitant, leading to a stepwise Tethyan platform stage evolution around the Paleocene/Eocene boundary. This szenario might be also effective for threatened coral reef sites.
\end{abstract}

(c) 2008 Elsevier B.V. All rights reserved.

\section{Contents}

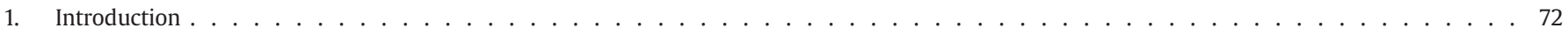

2. Correlation of shallow-water and pelagic biostratigraphic schemes . . . . . . . . . . . . . . . . . . . . . . . 73

\footnotetext{
* Corresponding author. Fax: +49421214515.

E-mail addresses: scheibne@uni-bremen.de (C. Scheibner), robert.speijer@ees.kuleuven.be (R.P. Speijer).

Fax: +32 16322980
} 
3. Carbonate facies changes and platform evolution in the Tethyan realm. . . . . . . . . . . . . . . . . . . . . . 75

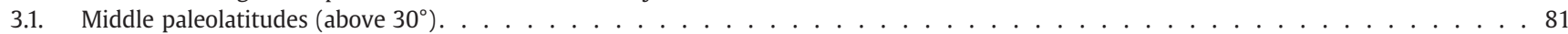

3.1.1. Northern Calcareous Alps $\left(43^{\circ} \mathrm{N}\right.$, locality 5, Figs. 4, 5) . . . . . . . . . . . . . . . . . . . . . 81

3.1.2. West Carpathians (W-Slovakia; $43^{\circ} \mathrm{N}$, locality 4, Figs. 4, 5) . . . . . . . . . . . . . . . . . . . . . 81

3.1.3. Northern Adriatic Platform $\left(38^{\circ} \mathrm{N}\right.$, locality 6 , Figs. 4,5$) \ldots \ldots \ldots$

3.1.4. Pyrenean platform (Spain, France; $38^{\circ} \mathrm{N}$, locality 1 , Figs, 4,5$) \ldots \ldots \ldots$

3.1.5. Maiella platform (Italy; $35^{\circ} \mathrm{N}$, locality 7 , Figs. 4,5$) \ldots \ldots \ldots$

3.1.6. Ionian Islands (Greece; $32^{\circ} \mathrm{N}$, locality 2 , Figs. 4,5$) \ldots \ldots \ldots$

3.1.7. Northern to central Turkey $\left(31^{\circ} \mathrm{N}\right.$, locality 16 , Fig. 4) . . . . . . . . . . . . . . . . . . . . . . . . 82

3.2. Intermediate paleolatitudes $\left(30^{\circ}-20^{\circ}\right) \ldots \ldots \ldots \ldots \ldots$

3.2.1. Tunisia $\left(26^{\circ} \mathrm{N}\right.$, locality 8 , Figs. 4,5$) \ldots \ldots \ldots \ldots$

3.2.2. Western High Atlas (Morocco; $26^{\circ} \mathrm{N}$, locality 15 , Figs. 4,5$) \ldots \ldots \ldots$

3.3. Low paleolatitudes (below $\left.20^{\circ}\right) \ldots \ldots \ldots \ldots \ldots$

3.3.1. Galala Mountains (Egypt; $20^{\circ} \mathrm{N}$, locality 3, Figs 4,5$) \ldots \ldots \ldots$

3.3.2. Sirte Basin (Libya; $20^{\circ} \mathrm{N}$, locality 9 , Figs 4,5$) \ldots \ldots \ldots \ldots$

3.3.3. Western Desert $\left(\right.$ Egypt; $19^{\circ} \mathrm{N}$, locality 10 , Figs. 4, 5) . . . . . . . . . . . . . . . . . . . . . . . . 85

3.3.4. Oman $\left(12^{\circ} \mathrm{N}\right.$, locality 11 , Figs. 4,5$) \ldots \ldots \ldots$

3.3.5. Tibet $\left(5^{\circ} \mathrm{N}\right.$, locality 12 , Figs. 4,5$) \ldots \ldots \ldots \ldots$

3.3.6. NW India, Pakistan $\left(5^{\circ} \mathrm{N}\right.$, locality 17 , Figs. 4, 5) . . . . . . . . . . . . . . . . . . . . . . . . . . . . 85

3.3.7. Shillong Plateau (NE India $5^{\circ} \mathrm{S}$, locality 13 , Figs. 4, 5) . . . . . . . . . . . . . . . . . . . . . 85

3.3.8. NW Somalia $\left(0^{\circ}\right.$, locality 14 , Figs 4,5$) \ldots \ldots \ldots$

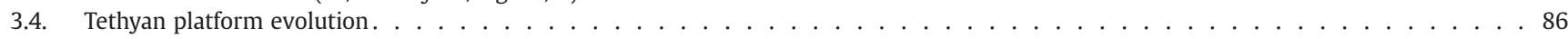

3.4.1. Platform stage I $(58.9-56.2 \mathrm{Ma}$; coralgal platform $) \ldots \ldots \ldots \ldots$

3.4.2. Platform stage II (56.2-55.5 Ma; coralgal and first larger foraminiferal platform) . . . . . . . . . . . . . . . . . . . . 86

3.4.3. Platform stage III (55.5- ?55.0 Ma; 2. larger foraminiferal platform) . . . . . . . . . . . . . . . . . . . . . . 86

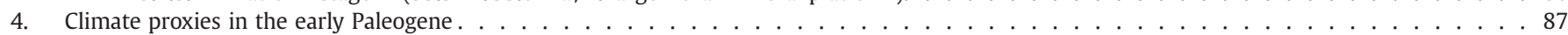

4.1. Absolute and latitudinal temperature changes. . . . . . . . . . . . . . . . . . . . . . . . . . . 87

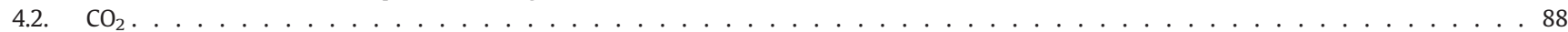

4.3. Precipitation, runoff and climate . . . . . . . . . . . . . . . . . . . . . . . . . . . . . . . . . . . . . . . . .

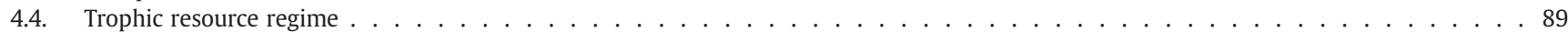

4.5. Early Paleogene climate modeling. . . . . . . . . . . . . . . . . . . . . . . . . . . . . . 89

5. Parameters controlling coral-distribution patterns . . . . . . . . . . . . . . . . . . . . . . . . . . 90

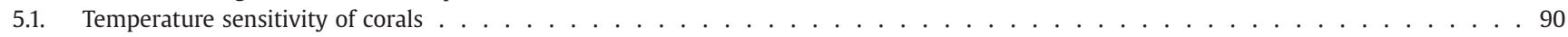

5.1.1. Corals and El Niño . . . . . . . . . . . . . . . . . . . . . . . . . . . . . . . . 90

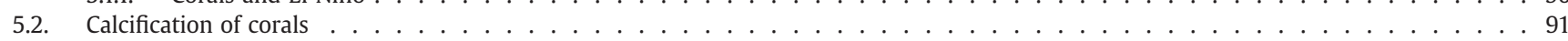

5.3. Variation of magnesium $/$ calcium $(\mathrm{Mg} / \mathrm{Ca})$ ratios $\ldots \ldots \ldots \ldots$

5.4. Early Paleogene coral reef distribution . . . . . . . . . . . . . . . . . . . . . . . . . . . . . . . . . . .

6. Parameters controlling larger foraminifera evolution . . . . . . . . . . . . . . . . . . . . . . . . . 91

6.1. Solar radiation sensitivity of larger foraminifera . . . . . . . . . . . . . . . . . . . . . . . . . . . . . 92

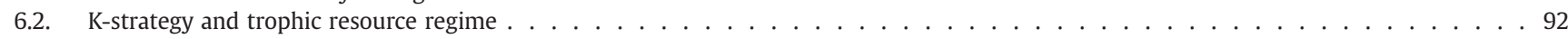

6.3. Global community maturation cycle $(\mathrm{GCM}$ cycle $) \ldots \ldots \ldots \ldots$

6.4. Early Paleogene larger foraminifera distribution . . . . . . . . . . . . . . . . . . . . . . . . . . . . . . . . . . . . . . 93

7. Causes for the platform evolution in the early Paleogene . . . . . . . . . . . . . . . . . . . . . . . . . . . . . .

7.1. Long-term causes . . . . . . . . . . . . . . . . . . . . . . . . . . . . . . . . . . . . . . . . . . 95

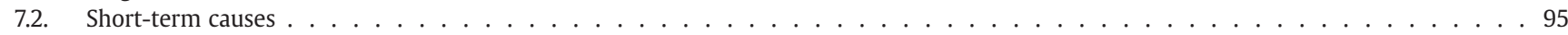

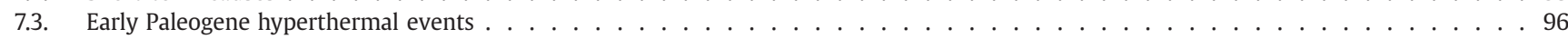

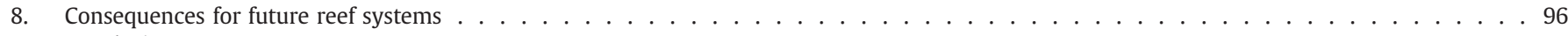

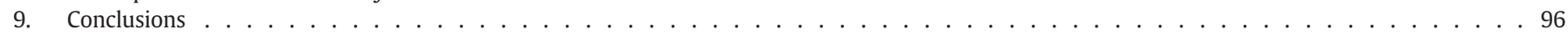

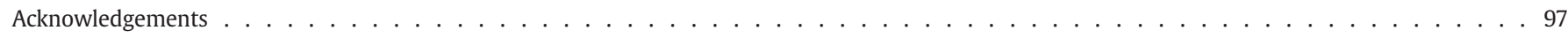

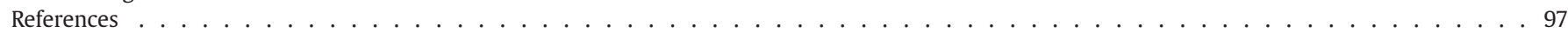

\section{Introduction}

Six main evolutionary reef faunas can be recognized throughout the Phanerozoic. These are composed of varying organisms (archaeocyathids, stromatoporids, calcisponges, bryozoans, rudists, tabulate, rugose and scleractinian corals) that build either reefs or reef mounds (James, 1983; Copper, 1988; Fig. 1). These six reef phases are terminated by periods of strongly diminished reef growth or are even absence of reefs. According to Copper (1988) the first 12 million years of the Paleogene are marked by an almost complete absence of reefs. But when considered in more detail, reefs of Paleocene to Eocene age are present and probably were much more common, but are either buried under sediments in tectonic active areas or occur in poor outcrops in the tropics (James, 1983). The sixth and last evolutionary fauna starts in the middle to late Eocene and is characterized by scleractinian corals. Before the reestablishment of the last reef phase, larger foraminifera, mainly nummulitids and alveolinids, thrived on the shallow-water carbonate platforms of the early Eocene.

In this study we summarize the current knowledge of early Paleogene reefs and carbonate platforms, concentrating on the Tethyan realm, as we personally investigated two areas (Egypt and Spain) and literature on this region is abundant.

The reasons for the existence of the different evolutionary reef faunas are probably manifold but to a certain amount due to reactions to environmental influences in extreme situations (Copper, 1988). The early Paleogene experienced the most pronounced long-term warming of the Cenozoic, starting in the late Paleocene (Selandian, 59 Ma) and culminating in the early Eocene (Ypresian, 51 Ma; Fig. 2) with the Early Eocene Climatic Optimum (EECO; Zachos et al., 2001). Shortterm warming events, known as hyperthermals, were superimposed on this long-term warming trend, the most prominent one being the Paleocene/Eocene Thermal Maximum (PETM; Zachos et al., 2001). 


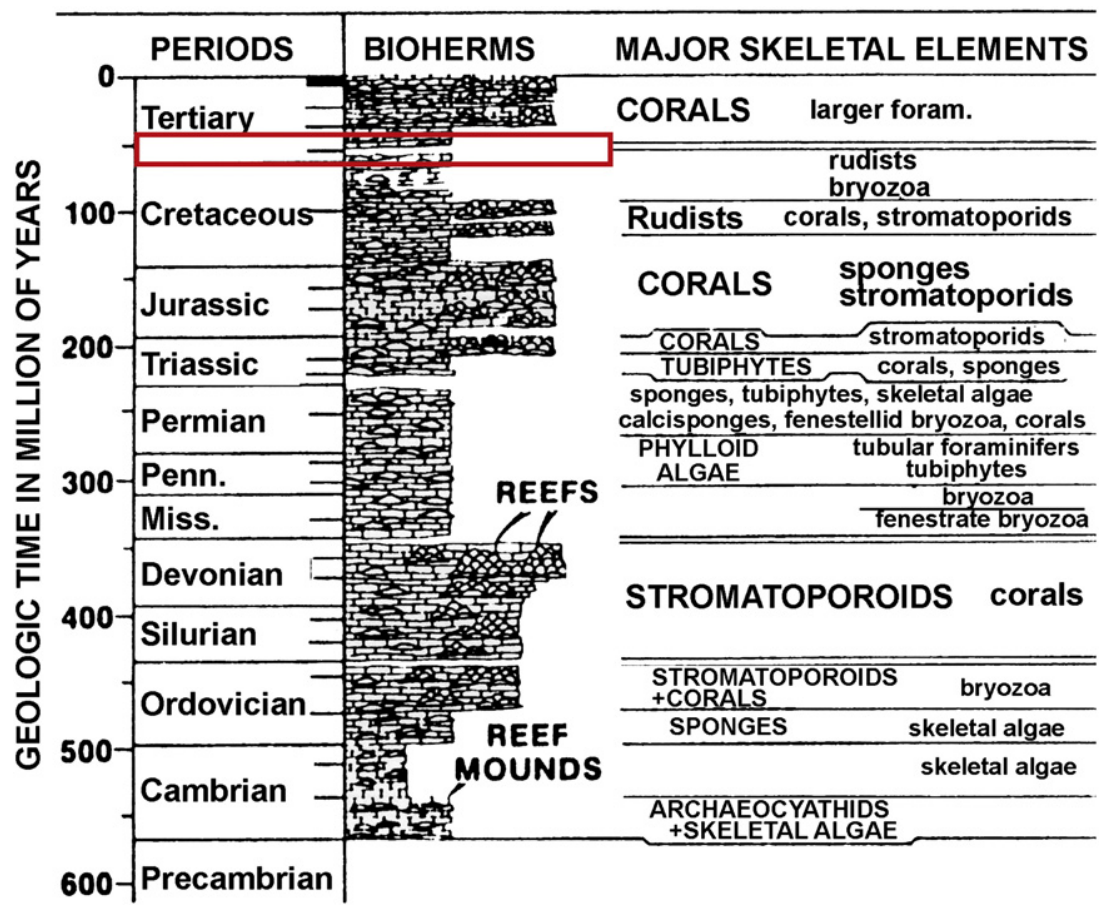

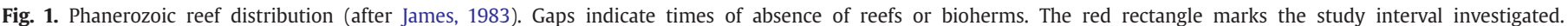
(For interpretation of the references to colour in this figure legend, the reader is referred to the web version of this article.)

These hyperthermals are accompanied by negative carbon isotope excursions (CIE; Zachos et al., 2001, 2007). During recent years paleoclimatic interest concentrated on short-term warming and related events in both marine and terrestrial realms, which were triggered during the PETM. In the deep ocean, the benthic extinction event (BEE) led to the extinction of approximately $40 \%$ of all smaller benthic foraminifers (Pak and Miller, 1992; Thomas, 1998, 2007), whereas in marginal seas smaller benthic foraminifera and ostracoda experienced milder turnovers (Speijer et al., 1996; Thomas, 1998; Speijer and Morsi, 2002). In contrast to the severe extinction event in deep-sea benthic communities, pelagic ecosystems show rapid diversification with high origination and extinction levels in planktonic foraminifera and calcareous nannofossils (e.g. Kelly et al., 1998; Kelly, 2002; Bralower et al., 2002; Gibbs et al., 2006a; Agnini et al., 2007; Petrizzo, 2007). The PETM also marks an important change in terrestrial vertebrate communities with a high number of new taxa in North America (e.g. Maas et al., 1995; Gingerich and Clyde, 2001; Gingerich, 2006). Recent studies of floral changes (Wyoming, USA, Wing et al., 2005) also indicate a transient rise in temperature on land during this time interval. The overall changes within the flora of high and low latitudes show a general warming trend from the latest Paleocene to early Eocene (Northern South America: Rull, 1999; Jaramillo and Dilcher, 2000; Jaramillo, 2002; Southern South America: Wilf et al., 2003; Antarctica: Francis and Poole, 2002; North America: Harrington et al., 2004; Harrington and Jaramillo, 2007). Only recently changes in the organism distribution on shallow-water carbonate platforms across the $\mathrm{P} / \mathrm{E}$ transition have been related to the PETM, but it was pointed out that these changes must also be seen in the context of the long-term early Paleogene warming (Scheibner et al., 2005; Scheibner and Speijer, in press). Some of the changes in shallow-water organism distribution, especially the rise of the larger foraminifera, have been known for decades but the correlation to deeper water biozonation schemes was uncertain. A new biostratigraphic correlation scheme between Tethyan platform and basin successions was proposed for the $\mathrm{P} / \mathrm{E}$ transition (Scheibner and Speijer, in press; Fig. 3), indicating that a main step in larger foraminifera evolution closely correlates with the PETM.
In this study we present an overview on late Paleocene-early Eocene platform evolution based on 17 Tethyan carbonate platforms, with focus on the middle paleolatitude setting of the Pyrenees (Rasser et al., 2005; Scheibner et al., 2007) and the low paleolatitude setting in Egypt (Scheibner et al., 2003a, 2005). This survey indicates that the Paleocene-Eocene interval was a time of profound changes in shallowwater carbonate settings in the Tethys. Overall, three platform stages are distinguished, starting with a late Paleocene coralgal reef stage, followed by a latest Paleocene transitional stage with coralgal reefs at middle latitudes and predominant larger foraminifera shoals at low latitudes. The $\mathrm{P} / \mathrm{E}$ boundary marks the onset of the third platform stage, characterized by a Tethys-wide domination of alveolinid and nummulitid deposits.

In addition to revealing the temporal and latitudinal evolution of Tethyan platforms, we discuss possible links between facies changes and the evolution of the main platform-building organisms (corals and larger foraminifera). We mainly focus on corals and larger foraminifera, since information on other carbonate producers such as algae is relatively scarce and inclusion may lead to biased interpretation. Furthermore, we evaluate platform development only in the light of exogenic forcing factors such as long- and short-term temperature rise, enhanced $\mathrm{CO}_{2}$ concentrations and varying trophic resource regimes.

\section{Correlation of shallow-water and pelagic biostratigraphic schemes}

A correlation scheme of platform and pelagic communities for the Paleocene-Eocene Tethys is provided by Serra-Kiel et al. (1998). This zonation scheme and the earlier biostratigraphic zonations of Hottinger (1960) for the alveolinids and Schaub (1981) for the nummulitids apply to the Tethyan realm as far south as Somalia and southeast to India, with exception of E India (Hottinger, 1971; Pignatti, 1994). This distribution and correlation potential define the geographic extent of our study. The exact correlation between the larger foraminifera zonation of Serra-Kiel et al. (1998) and the pelagic zonations of the magnetochronostratigraphic time scale (Berggren 


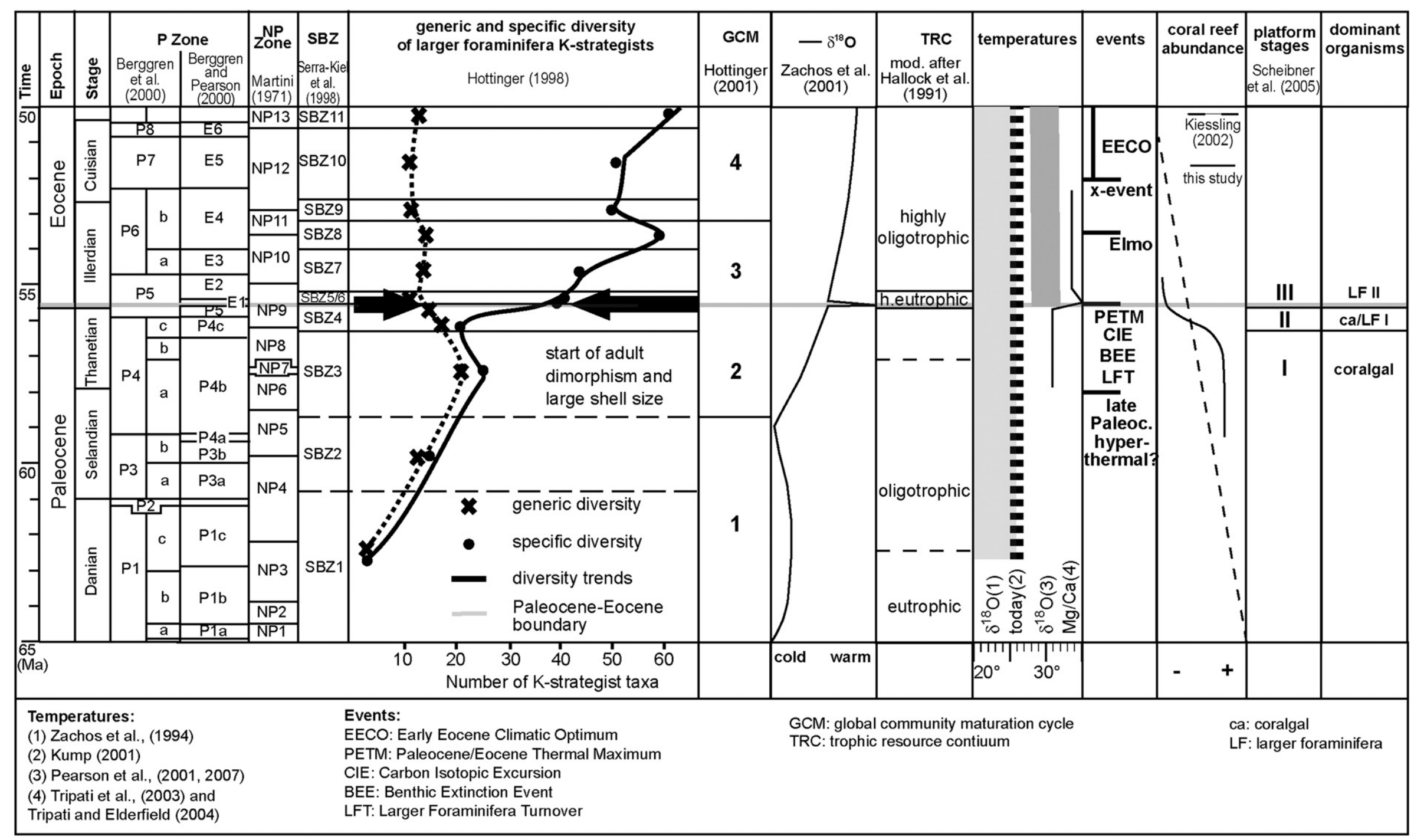




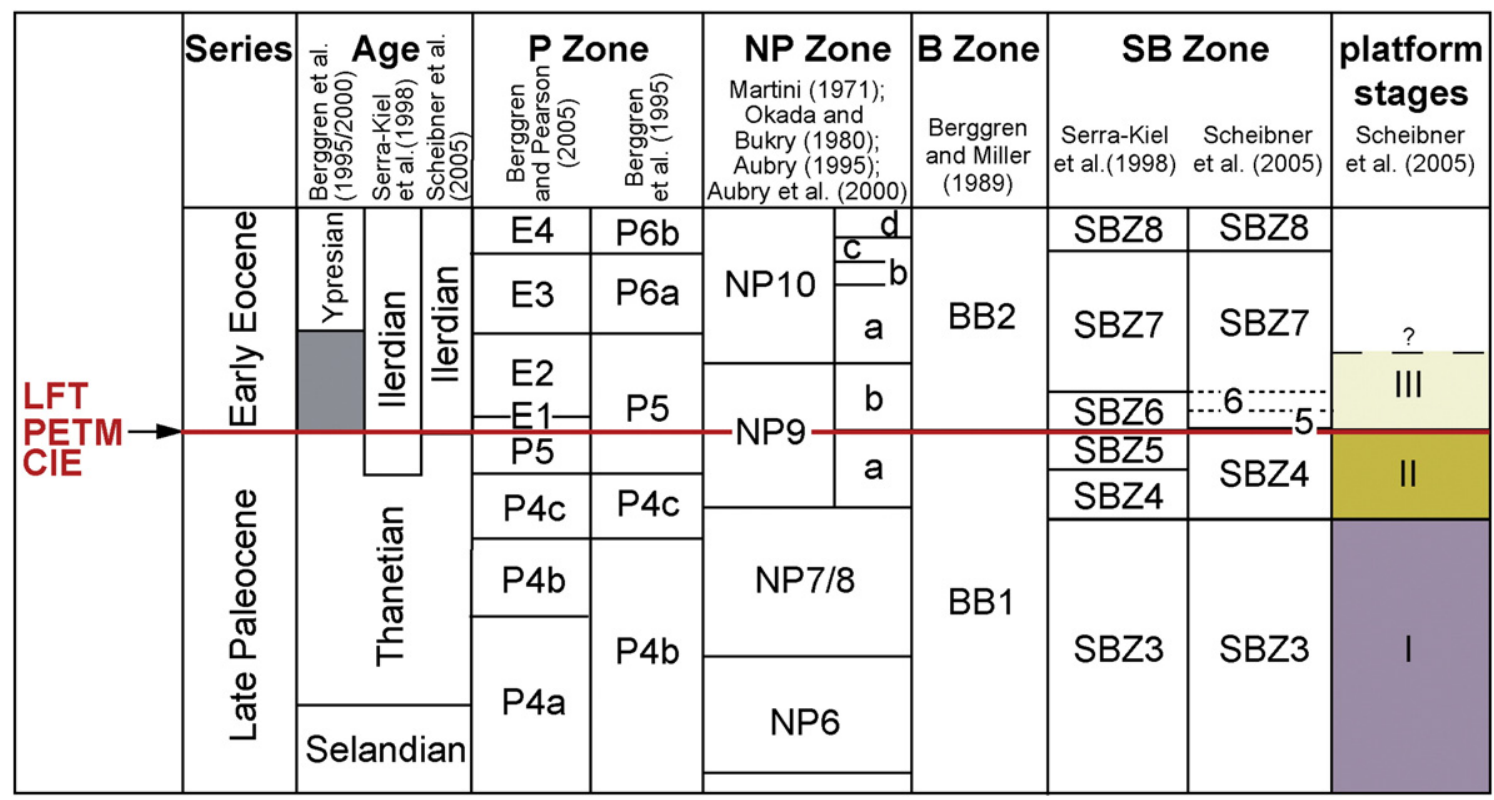

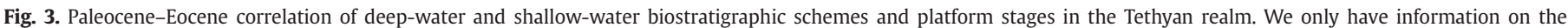

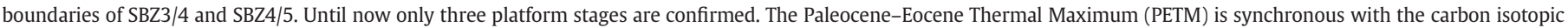

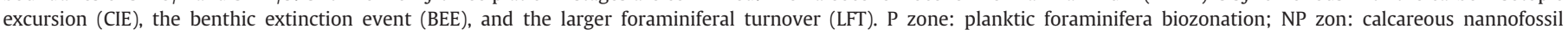
biozonation; B Zone: small benthic foraminifera biozonation; SB Zone: shallow benthic foraminifera zonation.

et al., 1995; Berggren and Pearson, 2005) remained unclear, especially around the P/E boundary. In 2003 the global boundary stratotype section and point (GSSP) for the basal Eocene was established in Dababiya (Egypt; Aubry and Ouda, 2003; Berggren, 2007), leading to agreement on the position of the $\mathrm{P} / \mathrm{E}$ boundary in both marine and non-marine sequences. The $\mathrm{P} / \mathrm{E}$ boundary at Dababiya can be correlated worldwide by means of the base of the negative carbon isotopic excursion (CIE), displaying a shift of about 2-3\% (Aubry and Ouda, 2003; Luterbacher et al., 2004). According to Luterbacher et al. (2004) the CIE is located within planktic foraminifer biozone P5 and calcareous nannofossil biozone NP9 in deep marine successions and between shallow benthic biozones SBZ5 and SBZ6 in platform successions (Fig. 3). Detailed investigations of the P/E-boundary interval in pelagic sediments refined the exact position of the carbon isotopic excursion to the boundary between zones P5 and E1 and NP9a and NP9b in the planktic foraminifera and calcareous nannofossils, respectively (Aubry, 1995; Berggren and Pearson, 2005). In the shallow benthic correlation scheme of Serra-Kiel et al. (1998) this level would correlate with the boundary between SBZ5 and SBZ6.

Another important event that occurred within the $\mathrm{P} / \mathrm{E}$ transition is the Larger Foraminifera Turnover (LFT after Orue-Etxebarria et al., 2001) that was first described from the Pyrenees by Hottinger and Schaub (1960). The LFT is characterized by the start of adult dimorphism and large shell size in larger foraminifera, especially the nummulitids and alveolinids, and marks the base of the Ilerdian (Hottinger and Schaub, 1960; Hottinger, 1998). This stage was introduced for marine deposits of the Tethyan realm for which no marine time equivalent in northern Europe exists (Hottinger and Schaub, 1960). Hottinger (1998) indicated that the LFT did not seem to correlate with any potential $\mathrm{P} / \mathrm{E}$-boundary marker based on planktic or deeper benthic organisms as proposed at that time. For practical reasons he proposed the base of the Ilerdian, the boundary between SBZ4 and SBZ5, as a criterion for delineating the P/E boundary in platform deposits, as this boundary can be easily recognized in the field by "hand lens". Recent investigations in Egypt show that this pragmatic placement of the $\mathrm{P} / \mathrm{E}$ boundary in the shallow-water domain happens to correlate with various pelagic and benthic boundary markers after all (Scheibner et al., 2005; Scheibner and Speijer, in press). Scheibner et al. (2005) demonstrated that the LFT and hence the boundary between SBZ4 and SBZ5 closely correlates with the CIE, marking the base of the Eocene (Fig. 3). In turn, this also means that the regional Ilerdian Stage represents only the lowermost Eocene as currently defined and it does not straddle the P/E boundary any more as previously considered (e.g. Serra-Kiel et al., 1998; Hottinger, 1998; Orue-Etxebarria et al., 2001).

(Note that a drawing error has occurred in Fig. 20.2 of the recent time scale by Gradstein et al. (2004). In the chapter on the Paleogene, Luterbacher et al. (2004) misplaced the P/E boundary in the larger foraminifera biozonation between the Ilerdian and the Cuisian stages between SBZ9 and SBZ10.)

\section{Carbonate facies changes and platform evolution in the Tethyan realm}

In the following chapter, we summarize literature data on facies changes and platform evolution on carbonate platforms in the early Paleogene (Thanetian-Ypresian) in the Tethyan realm. The dataset is subdivided into three regions according to paleolatitude: middle paleolatitudes (above $30^{\circ}$ ), intermediate paleolatitudes $\left(20^{\circ}-30^{\circ}\right)$ and low paleolatitudes (below $20^{\circ}$ ). The carbonate platforms located in the middle paleolatitudes are all located at the northern rim of the Tethys, while the carbonate platforms of the intermediate and low paleolatitudes are located at the southern rim of the Tethys. Apart from the study on NE India (Jauhri and Agarwal, 2001; Jauhri, 1998), which is situated at $5^{\circ} \mathrm{S}$, all studies are located on the northern hemisphere. Within this overview we present the two Paleocene-Eocene transitions in carbonate platforms, which we studied ourselves, in more detail: one study from middle latitudes in the Pyrenees (Pujalte et al., 1993, 2003a; Baceta et al., 2005; Rasser et al., 2005; Scheibner et al., 2007; locality 1, Figs. 4, 5), and one study from low latitudes in Egypt (Scheibner et al., 2003a, 2005, locality 3, Figs. 4, 5). The Tethyan platform evolution is summarized and subdivided into three time slices, two Paleocene intervals (SBZ3 and SBZ4) and one lowermost Eocene (SBZ5/6) time slice (Fig. 5). For the compilation of the different studies a uniform time frame had to be established, as the studies adopt various age/epoch definitions. For example, the Paleocene is in some instances only subdivided into Danian and Thanetian and in 

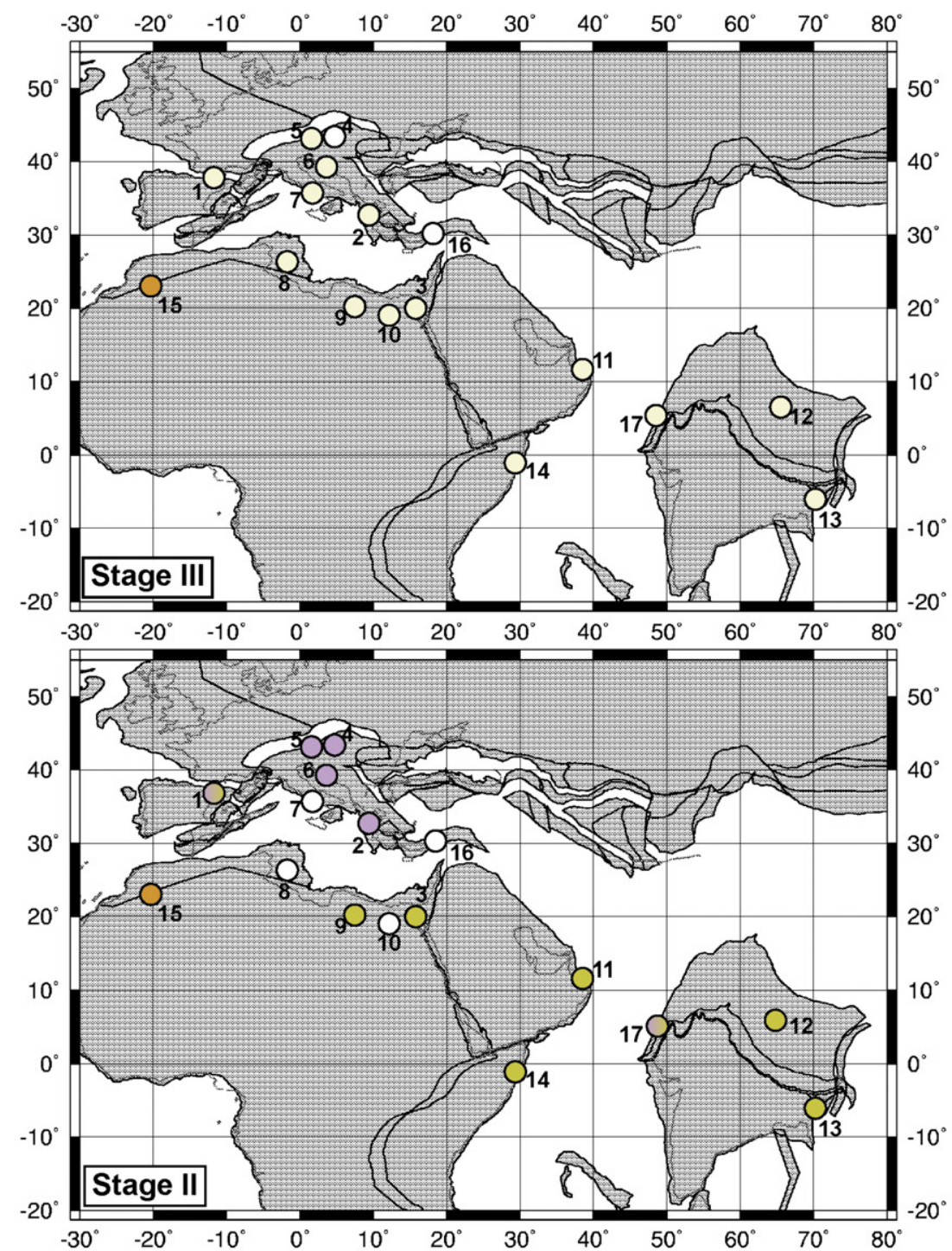
organism association
O no information
O exceptional fauna
O larger foraminifera II
O larger foraminifera I
O coralgal reefs

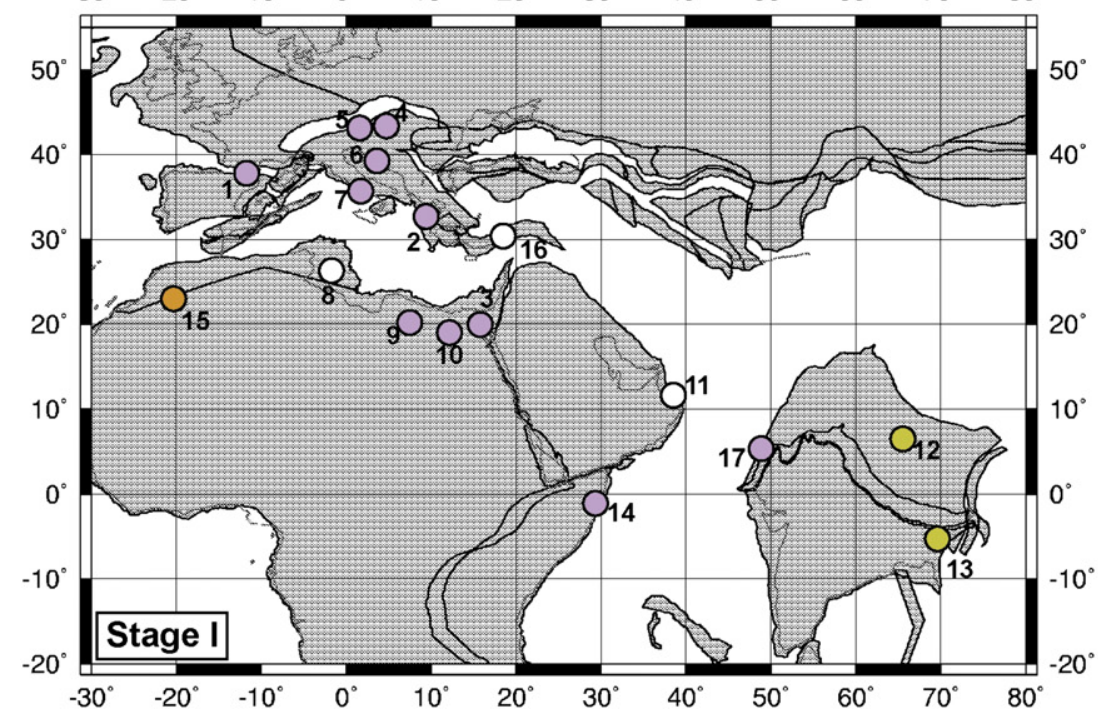

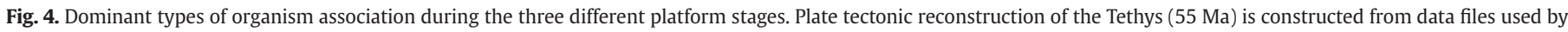

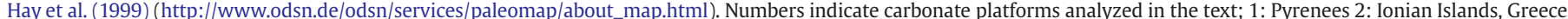

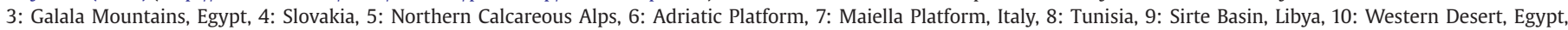

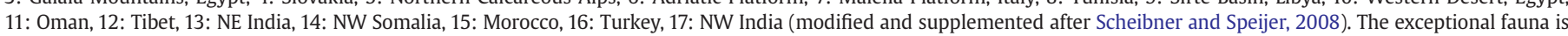
characterized by oyster, bryozoan and echinoids (see Fig. 5). 


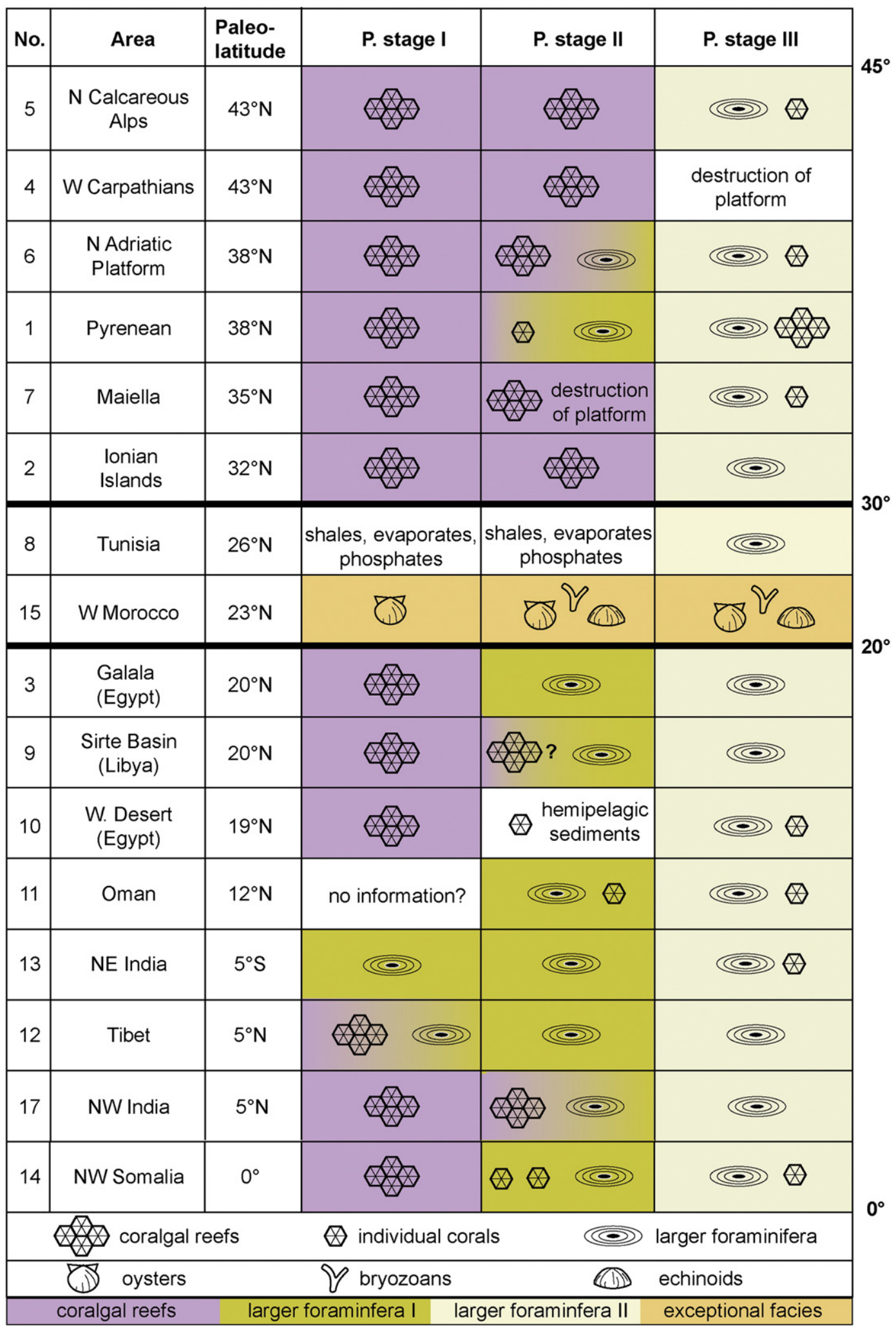

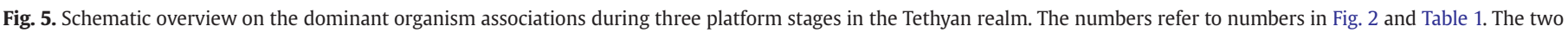

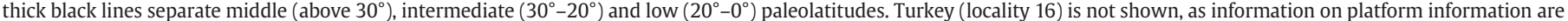
too vague (modified and supplemented after Scheibner and Speijer, 2008).

other studies the Paleocene also includes the Ilerdian, or no subdivision into shallow benthic zones exists or larger foraminifera were not identified. We did not distinguish between SBZ5 and SBZ6 in this study, as an unambiguous determination of these biozones was not possible. In most studies a subdivision with the mentioned larger foraminiferal index species was possible but in some studies the exact time frame is less certain. Some problems arose by incorporating studies that did not deal with platform evolution but investigated only 
Table 1

Overview of the investigated platform areas. Displayed are the number (see Figs. 3, 4), area, time span of the study, paleolatitude, three platform stages, references and comments

\begin{tabular}{|c|c|c|c|c|c|c|c|c|}
\hline Number & Area & Time span & $\begin{array}{l}\text { Paleo } \\
\text { latitude }\end{array}$ & $\begin{array}{l}\text { P-stage I } \\
\text { (SBZ 1-3) }\end{array}$ & $\begin{array}{l}\text { P-stage II } \\
\text { (SBZ4) }\end{array}$ & $\begin{array}{l}\text { P-stage III } \\
\text { (SBZ5-6) }\end{array}$ & Reference & Comments \\
\hline 5 & $\begin{array}{l}\text { Northern } \\
\text { Calcareous } \\
\text { Alps }\end{array}$ & $\begin{array}{l}\text { Paleocene- } \\
\text { Eocene }\end{array}$ & $43^{\circ} \mathrm{N}$ & Thanetian: coralgal reefs & Thanetian: coralgal reefs & $\begin{array}{l}\text { Coral growth restrained, no } \\
\text { accumulation of reefs, } \\
\text { encrusting foraminifera }\end{array}$ & $\begin{array}{l}\text { Moussavian, (1984); } \\
\text { Tragelehn (1996); } \\
\text { Kazmer et al. (2003) }\end{array}$ & $\begin{array}{l}\text { No subdivision of SBZ } 3 \text { and } 4 \text {, llerdian is } \\
\text { considered Paleocene }\end{array}$ \\
\hline 4 & $\begin{array}{l}\text { West } \\
\text { Carpathians, } \\
\text { western } \\
\text { Slovakia }\end{array}$ & Paleogene & $43^{\circ} \mathrm{N}$ & $\begin{array}{l}\text { Coralgal reef complex in the } \\
\text { Danian and Thanetian }\end{array}$ & $\begin{array}{l}\text { Destruction of the reefs at the } \\
\text { end of the Thanetian, question, } \\
\text { whether within SBZ4 or end of } \\
\text { SBZ3 }\end{array}$ & No information & $\begin{array}{l}\text { Scheibner (1968); K`hler } \\
\text { et al. (1993); Kazmer } \\
\text { et al. (2003) }\end{array}$ & LF indicate only SBZ3 \\
\hline \multirow[t]{2}{*}{6} & $\begin{array}{l}\text { Northern } \\
\text { Adriatic } \\
\text { Platform }\end{array}$ & Paleocene & $38^{\circ} \mathrm{N}$ & $\begin{array}{l}\text { Coralgal reefs, abundant } \\
\text { larger foraminifera }\end{array}$ & $\begin{array}{l}\text { Coralgal reefs, abundant larger } \\
\text { foraminifera }\end{array}$ & $\begin{array}{l}\text { Alveolina and Nummulites in } \\
\text { rockforming quantities, some } \\
\text { corals occur as well }\end{array}$ & $\begin{array}{l}\text { Turnsek and Drobne (1998), } \\
\text { Drobne et al. (1988); } \\
\text { Jurkovsek et al. (1996); Babic } \\
\text { and Zupanic (1981); Turnsek } \\
\text { and Kosir (2004); Vlahovic } \\
\text { et al. (2005) }\end{array}$ & $\begin{array}{l}\text { Thanetian starts on top of Danian, } \\
\text { no Selandian }\end{array}$ \\
\hline & & $\begin{array}{l}\text { Paleocene- } \\
\text { earliest Eocene }\end{array}$ & & $\begin{array}{l}\text { Small benthic foraminifera } \\
\text { dominate, corals are almost } \\
\text { absent }\end{array}$ & $\begin{array}{l}\text { Coralgal reefs, abundant larger } \\
\text { foraminifera }\end{array}$ & $\begin{array}{l}\text { Dominated by larger } \\
\text { foraminifera }\end{array}$ & Zamagni et al (2008) & \\
\hline \multirow[t]{6}{*}{1} & $\begin{array}{l}\text { Pyrenean } \\
\text { platform }\end{array}$ & $\begin{array}{l}\text { Paleocene- } \\
\text { ealiest Eocene }\end{array}$ & $38^{\circ} \mathrm{N}$ & Reef phases $1-5$ & $\begin{array}{l}\text { Mainly Assilina, no reef } \\
\text { bioconstructions }\end{array}$ & $\begin{array}{l}\text { Mainly Nummulites, Alveolinds, } \\
\text { some small coral reefs }\end{array}$ & Baceta et al. (2005) & \\
\hline & & $\begin{array}{l}\text { Late Paleocene- } \\
\text { earliest Eocene }\end{array}$ & & & $\begin{array}{l}\text { Algal dominated, some small } \\
\text { coral reefs (Campo), }\end{array}$ & $\begin{array}{l}\text { Mainly Nummulites, Alveolinds, } \\
\text { some small coral reefs }\end{array}$ & Scheibner et al. (2007) & \\
\hline & $\begin{array}{l}\text { Pyrenean } \\
\text { platform }\end{array}$ & $\begin{array}{l}\text { late Paleocene- } \\
\text { earliest Eocene }\end{array}$ & & Coral reefs & Different types of nummulitids & Nummulites, Assilina & Pujalte et al. (2003a) & Discussion on correlation of LFT and PETM \\
\hline & $\begin{array}{l}\text { Pyrenean } \\
\text { platform }\end{array}$ & $\begin{array}{l}\text { Paleocene-early } \\
\text { Eocene }\end{array}$ & & & & & $\begin{array}{l}\text { Pujalte et al. (1993, 2003b); } \\
\text { Payros et al. (2000); }\end{array}$ & \\
\hline & $\begin{array}{l}\text { Pyrenean } \\
\text { platform }\end{array}$ & Ilerdian-Cuisian & & & & $\begin{array}{l}\text { Coralalgal patch-reefs and } \\
\text { mounds, Solenomeris reef } \\
\text { mounds }\end{array}$ & $\begin{array}{l}\text { Eichenseer and Luterbacher } \\
\text { (1992) }\end{array}$ & Sequence stratigraphy, stratigraphy \\
\hline & $\begin{array}{l}\text { Alaric } \\
\text { Mountain, } \\
\text { Pyrenean } \\
\text { Platform }\end{array}$ & Early Eocene & & & & $\begin{array}{l}\text { Solenomeris reef (encrusting } \\
\text { foraminifera) }\end{array}$ & $\begin{array}{l}\text { Perrin (1992); Plaziat and } \\
\text { Perrin (1992) }\end{array}$ & \\
\hline 7 & $\begin{array}{l}\text { Maiella } \\
\text { Platform, } \\
\text { Italy }\end{array}$ & Danian-Eocene & $35^{\circ} \mathrm{N}$ & $\begin{array}{l}\text { Coralgal reef complex, larger } \\
\text { foraminifera: Cribrobulimina } \\
\text { carniolica, Fallotella } \\
\text { alavensis, }\end{array}$ & $\begin{array}{l}\text { Larger foraminifera: Ranikothalia } \\
\text { sindensis. Shortly after the reef } \\
\text { formation and still in the } \\
\text { Paleocene they were destroyed. }\end{array}$ & $\begin{array}{l}\text { Dominated by alveolinids, } \\
\text { coralgal-reefs are less im- } \\
\text { portant in early to middle } \\
\text { Eocene }\end{array}$ & $\begin{array}{l}\text { Moussavian and Vecsei } \\
\text { (1995); Vecsei and } \\
\text { Moussavian (1997) }\end{array}$ & $\begin{array}{l}\text { Thanetian starts on top of Danian, no } \\
\text { Selandian. Coralgal-reef communities } \\
\text { differ between the Danian/lower Thanetian } \\
\text { and the upper Thanetian. Large late Eocene } \\
\text { (Priabonian and Rupelian) coral reefs. }\end{array}$ \\
\hline
\end{tabular}




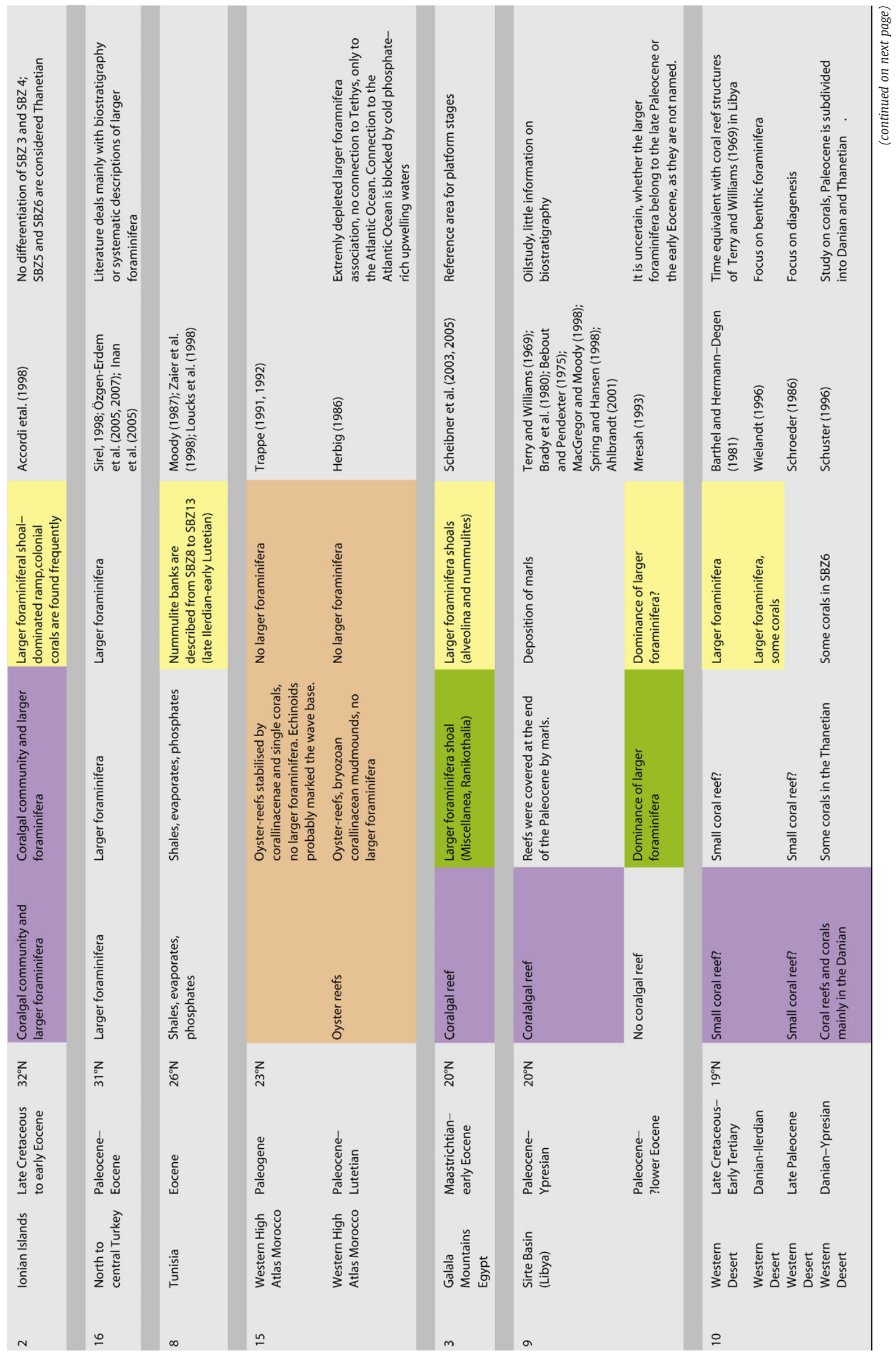




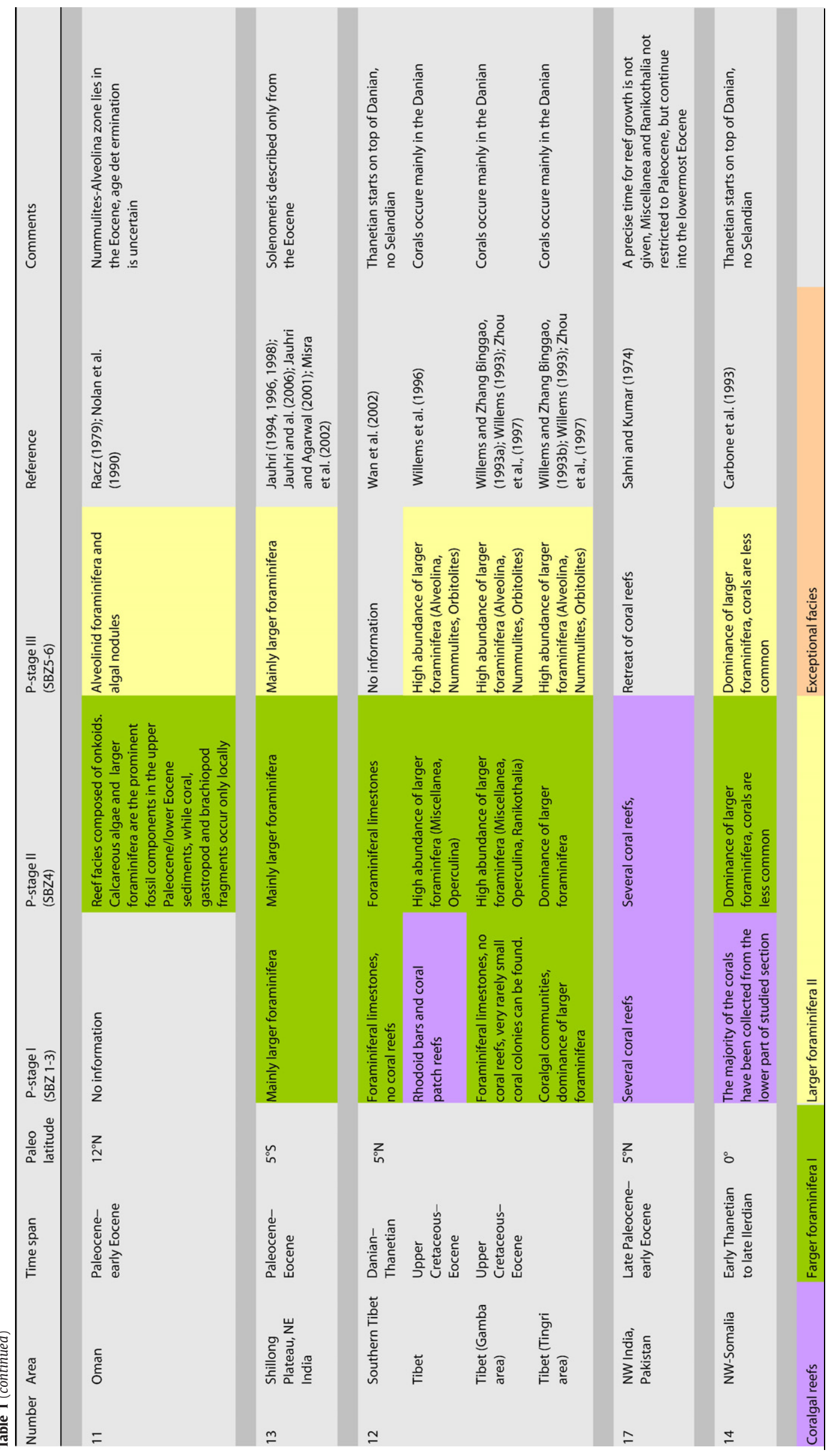


a specific group of organisms (e.g. corals, larger foraminifera) or diagenetic features. Therefore these studies where not used to be representative for the various areas but contribute only additional information. In Table 1 we summarize the platform evolution and topic studied of every individual location and reference. Paleolatitudes and the paleogeographic map (Fig. 4) are derived from http://www. odsn.de/odsn/services/paleomap/about_map.html (Hay et al., 1999).

\subsection{Middle paleolatitudes (above $30^{\circ}$ )}

\subsubsection{Northern Calcareous Alps $\left(43^{\circ} \mathrm{N}\right.$, locality 5, Figs. 4, 5)}

In the Northern Calcareous Alps coralgal reefs thrived from the Danian to the Thanetian indicated by the index fossils of SBZ3 (Glomalveolina primaeva) and SBZ4 (Glomalveolina levis; Moussavian, 1984; Tragelehn, 1996). Together with the Carpathian reefs (see Section 3.1.2) the reefs of the Northern Calcareous Alps formed a barrier-reef system, consisting of a number of individual reefs (Moussavian, 1984). Kazmer et al. (2003) created paleogeographic maps for six time slices (63 Ma, $52 \mathrm{Ma}, 46 \mathrm{Ma}, 40 \mathrm{Ma}, 38 \mathrm{Ma}, 36 \mathrm{Ma}$ ) of the Northern Calcareous Alps to the Carpathians. The map for $63 \mathrm{Ma}$ (Danian) showed a continuous reef belt, whereas at $52 \mathrm{Ma}$ (Ypresian) no such reef belt existed. During the early Ilerdian (SBZ5/6) red algae and bryozoan colonies together with encrusting foraminifera (Gypsina (=Acervulina) ogormani) were dominant within the encrusting organism association, while larger foraminifera (Ranikothalia, Discocyclina) thrived on the open shelf. During middle to late Ilerdian times Nummulites, Operculina and Assilina replaced Ranikothalia and alveolinids became more diverse. Coral growth - mostly consisting of solitary corals - was very restricted and did not contribute to the construction of reefs during the Ilerdian (Moussavian, 1984).

\subsubsection{West Carpathians (W-Slovakia; $43^{\circ} \mathrm{N}$, locality 4, Figs. 4, 5)}

During the Thanetian a coral reef complex thrived in the West Carpathians, forming fringing reefs at the platform margin and patch reefs in the back-reef area (Scheibner, 1968; Köhler et al., 1993; Kazmer et al., 2003). G. primaeva, Discocyclina seunesi, and Miscellanea juliettae prove SBZ3 while Daviesina garumnensis and Operculina azilensis prove SBZ4. At the end of the Paleocene the whole reef complex was completely destroyed and no younger strata were recorded.

\subsubsection{Northern Adriatic Platform $\left(38^{\circ} \mathrm{N}\right.$, locality 6, Figs. 4, 5)}

During the Danian to Thanetian corals formed local patch reefs on the Northern Adriatic Platform (Babic and Zupanic, 1981; Drobne et al., 1988; Jurkovsek et al., 1996; Turnsek and Drobne, 1998; Turnsek and Kosir, 2004; Vlahovic et al., 2005). In the uppermost Thanetian corals are often overgrown by red algae. Within SBZ3 and SBZ4 larger foraminifera are also abundant. The lowermost Eocene $(\mathrm{SBZ} / 6)$ is dominated by alveolinid-nummulitid limestones, whereas red algae and corals occur subordinately. Zamagni et al. (2008) analyzed two sections east of Trieste paleoecologically and sedimentologically and described three facies types in SBZ4: 1 Orthophragminid-dominated facies with a poorly diverse foraminiferal assemblage and calcareous red algae. 2. Assilinadominated facies with assilinids and miscellaneids and associated calcareous red algae and isolated coral colonies. 3. Bioconstructordominated facies with encrusting foraminifera, which together with corals build small coral-microbial reef mounds. The lower Eocene is dominated by an alveolinid-nummulitid assemblage, although Turnsek and Kosir (2004) described small patches of coralgal reef facies in the Ilerdian within the nummulitid assemblage.

\subsubsection{Pyrenean platform (Spain, France; $38^{\circ} \mathrm{N}$, locality 1, Figs. 4, 5)}

In this study we assign the Pyrenean platform to the Tethyan realm, as it shows many similarities with Tethyan platforms S.s., yet it was situated along a precursor gulf of the present Bay of Biscay (Fig. 4).

The Paleocene to lowermost Eocene of the southwestern Pyrenees and Basque areas can be subdivided into five depositional sequences, with the first four sequences belonging to the Paleocene $(1.3,1.4,2.1$, 2.2 ) and the fifth belonging to the Eocene (2.3; Pujalte et al., 1993). Recently, Payros et al. (2000), Pujalte et al. (2003a,b) and Baceta et al. (2005) renamed and modified the boundaries of the different depositional sequences. These authors subdivided the Paleocene into two Danian sequences (Da-1 and Da-2) and two Thanetian sequences (Th-1 and Th-2) and subdivided the Eocene sequence 2.3 into four individual Ilerdian sequences (IL-1 to IL-4). The temporal and spatial evolution of the Paleocene Pyrenean reefs was analyzed in Baceta et al. (2005; Fig. 6), recognizing five phases of reef development, with the first phase belonging to sequence Da-1 and the second and third phase belonging to sequence Da-2. In the first three reefbuilding phases corals dominated the coralgal reefs, while calcareous algae occurred only subordinately. Reef phases 4 and 5 belong to sequence Th- 1 . In these last two reef phases encrusting calcareous algae dominated the bioconstructions, while corals played only a minor role. For sequence Th-2 Baceta et al. (2005) noticed that the reef bioconstructions almost vanished. In the following general overview we use the depositional sequences of Payros et al. (2000) and discuss only sequences Th-1, Th-2, IL-1 and IL-2.

3.1.4.1. Sequence Th-1. The outer carbonate platform is composed of fossil-rich sandy limestones and coralgal reefal limestones, while basinwards of the outer platform 50-m-thick megabreccias were deposited. The inner platform larger foraminifera G. primaeva, Fallotella alavensis, and Coskinon raijkae indicate a SBZ3 age for this sequence. According to Pujalte et al. (1993) the beginning of this sequence (base of sequence 2.1 approximates sequence Th-1) is approximately contemporaneous with the most prominent sea-level fall in the Paleocene. In contrast to the first three reef-building phases of Baceta et al. (2005), which are dominated by corals, the fourth and fifth phase, belonging to sequence Th-1, are characterized by the deposition of calcareous algae as the main contributors to reef growth, whereas corals occur only subordinately.

3.1.4.2. Sequence Th-2. The outer carbonate platform margin is composed of sandy limestones with open platform larger foraminifera, whereas the inner platform is made of wackestones and packstones with alveolinids and miliolids. The fossil assemblages with Assilina yvettae and 0 . azilensis indicate a SBZ4 age for this sequence. Sequence Th-2 is identical to the upper part of the Navarri Formation in the Campo section (Payros et al., 2000). Scheibner et al. (2007) reported a dominance of red algae in part C (thickness of $32 \mathrm{~m}$ ) of the upper part of the Navarri Formation in Campo. In the upper $6 \mathrm{~m}$ coralgal bound- to rudstones dominate the strata. Baceta et al. (2005) reported the absence of any reef bioconstructions in the Pyrenean region for sequence Th-2 and mentioned the occurrence of Assilina beds (Fig. 5).

3.1.4.3. Sequences $I L-1$ to $I L-2$. The depositional sequence 2.3 of Pujalte et al. (1993) is subdivided by Payros et al. (2000) and Pujalte et al. (2003a,b) into four depositional sequences (IL-1 to IL-4). The foraminiferal assemblage in sequences IL- 1 and IL-2 is characteristic for SBZ5/6. In the southwest Pyrenean and Basque areas sequence 2.3 is only poorly represented, while well developed in the central and eastern Pyrenees (Pujalte et al., 1993). The outer carbonate platform is composed of nummulitid-rich marls (Pujalte et al., 2003a). The inner carbonate platform deposits of sequences IL-1 and IL-2, present in the Campo and Serraduy sections consist in the lower part of sequence IL-1 of marls to siliciclastics, while the remaining parts of sequence IL-1 and sequences IL-2 consist of larger foraminifera facies with abundant alveolinids, the so-called "Alveolina limestone". A small interval $(4 \mathrm{~m})$ in the lower part of sequence IL-2 is composed of coral wacketo boundstone (Scheibner et al., 2007). Although larger foraminifera dominate both sequences, Eichenseer and Luterbacher (1992) described several isolated coralgal patch reefs within these sequences in the Tremp basin in the Central Southern Pyrenees. In addition they 


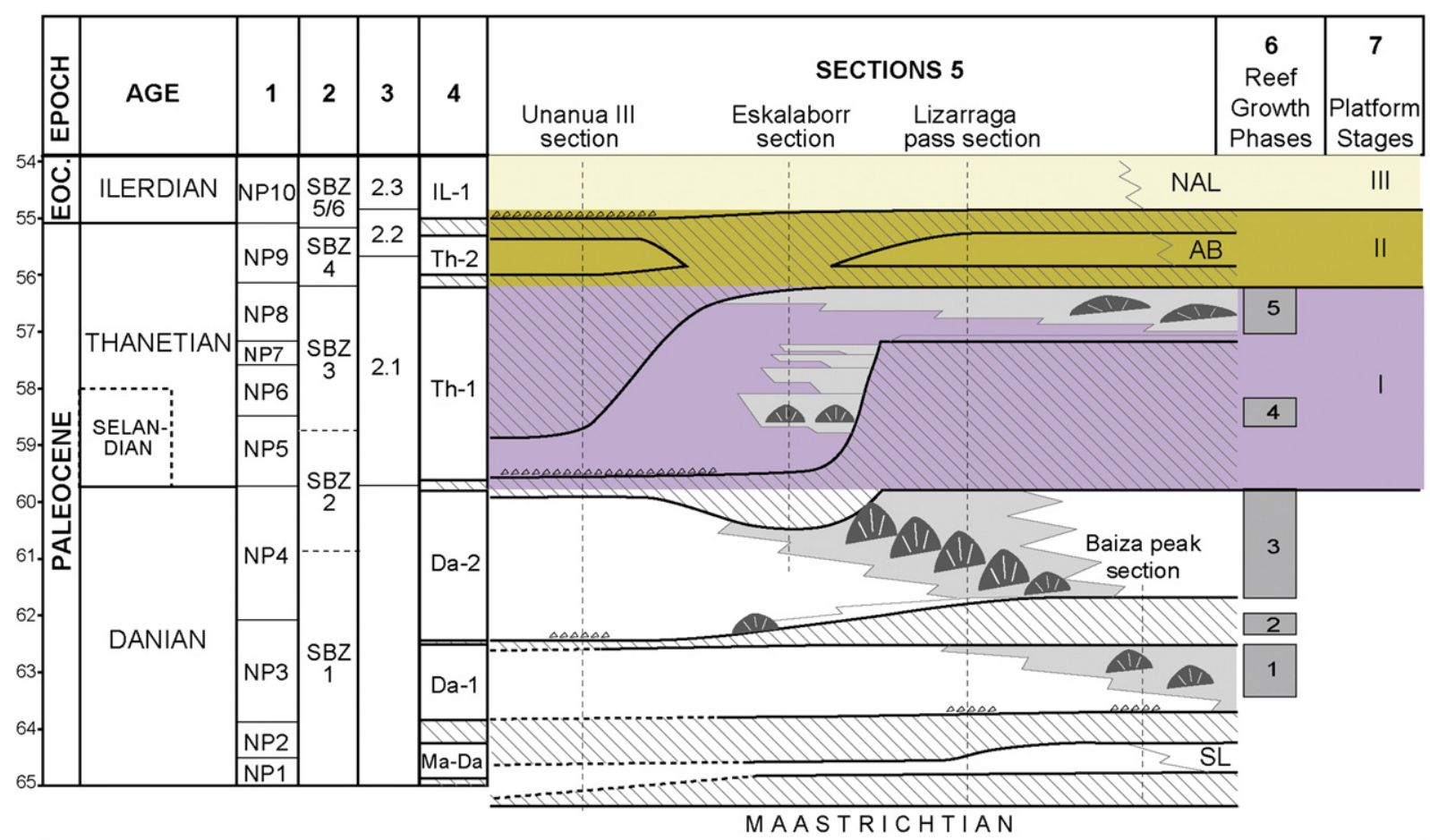

\section{NAL: Nummulites-A/veolina limestone $\mathrm{AB}$ : Assilina beds}

SL: Solenomeris limestone 1. coralgal reef constructions
1: calcareous nannofossil biozonation (Martini, 1971)

2: shallow-benthic biozonation (Serra-Kiel et al., 1998)

3: sequences (Pujalte et al., 1993)

4: sequences (Payros et al., 2000)

5: sections (Baceta et al., 2005)

6: reef growth phases (Baceta et al., 2005)

7: platform stages (Scheibner et al., 2005)

Fig. 6. Reef growth phases and platform stages of the Paleocene to lower Eocene in the Urbasa-Andia plateau (Pyrenees), modified after Baceta et al. (2005).

also described foraminiferal reef mounds built up by Solenomeris (Acervulina). Similar lower Eocene foraminiferal reef mounds have been described from the northern rim of the Basque Basin at the Alaric Mountains in SE France, where Solenomeris built km-sized reefs (Plaziat and Perrin, 1992).

\subsubsection{Maiella platform (Italy; $35^{\circ} \mathrm{N}$, locality 7 , Figs. 4, 5)}

In the Maiella platform, two coralgal reef-building intervals, a first in the Danian to early Thanetian and a second in the late Thanetian were described by Moussavian and Vecsei (1995) and Vecsei and Moussavian (1997). The overall stratigraphy is unfortunately hampered by redeposition of the reef facies as the reefs were destroyed shortly after their formation. But nevertheless, the larger foraminifera described by Moussavian and Vecsei (1995) indicate deposition of the second reef interval during SBZ3 (Cribrobulimina carniolica, F. alavensis, Miscellanea sp.) to SBZ4 (Ranikothalia sindensis, Miscellanea sp.). While the Danian to early Thanetian reefs probably constructed only small patch reefs, the late Thanetian reefs may have formed a small barrier (Vecsei and Moussavian, 1997). A new platform build up was initiated during the early Eocene, dominated by alveolinids, whereas coralgal reefs were virtually absent (Vecsei and Moussavian, 1997). Coral reefs in this area only started to diversify during the late Eocene (Priabonian).

\subsubsection{Ionian Islands (Greece; $32^{\circ} \mathrm{N}$, locality 2, Figs. 4, 5)}

A very well documented example for a biostratigraphically wellconstrained carbonate platform evolution is given in Accordi et al.
(1998). In the western part of Cephalonia on the Ionian Islands (Greece) a late Cretaceous rimmed platform evolved to an early Eocene homoclinal ramp. From the late Cretaceous to the early Eocene Accordi et al. (1998) established the following sedimentary model: Stage 1: Late Cretaceous orbitoid/rudist shoal-dominated rimmed shelf. Stage 2: Paleocene (up to SBZ3/SBZ4) coral/algal sandy blankeddominated ramp. SBZ3 and SBZ4 are not separated, but all facies associations containing corals were attributed to both biozones, suggesting coral growth up to the P/E boundary. At the same time larger foraminifera-dominated facies were deposited in the peritidal and middle to outer ramp environments. Note that all late Thanetian age assignments of Accordi et al. (1998) were converted into early Eocene as these authors used the term late Thanetian in the sense of early Ilerdian (SBZ5 and SBZ6). Stage 3: Early Eocene (SBZ5/SBZ6) larger foraminiferal shoal-dominated ramp. Additionally remains of bivalves, gastropods, echinoids, red algae and colonial corals occur frequently.

\subsubsection{Northern to central Turkey $\left(31^{\circ} \mathrm{N}\right.$, locality 16 , Fig. 4)}

Paleocene to Eocene carbonate successions are well known in Turkey, but earlier studies deal mainly with biostratigraphy or systematic descriptions of larger foraminifera (Sirel, 1998 and references herein; Inan et al., 2005; Özgen-Erdem et al., 2005, 2007). Facies associations or organisms other than larger foraminifera are mentioned rarely. From literature data it is not possible to draw a coherent picture on the dominant organism distribution in the 
early Paleogene of Turkey. The focus on larger foraminifera in literature could perhaps imply that Paleocene to lower Eocene deposits are dominated by larger foraminifera deposits. On the other hand Özgen-Erdem et al. (2005) stated that the "Danian, Selandian and Thanetian units are characterized by reefal (organic buildup), shelf lagoon, shelf and tidal flat paleoenvironments. The Ilerdian units are represented by reefal and shelf lagoon environments". From this paper it is not clear what is meant with the term reefal. Since it remains ambiguous whether coral reefs or possibly accumulations of larger foraminifera are meant, we refrain from showing this locality in the schematic overview (Fig. 5).

\subsection{Intermediate paleolatitudes $\left(30^{\circ}-20^{\circ}\right)$}

\subsubsection{Tunisia $\left(26^{\circ} \mathrm{N}\right.$, locality 8 , Figs. 4,5$)$}

The early to middle Paleocene of the shallow Gafsa Basin in southern Tunisia is characterized by evaporitic marls and shales of the Selja Formation, indicative of restricted environments. During the late Paleocene/early Eocene marls and shales with intercalated evaporites and phosphatic limestones of the Chouabine and Kef Eddour Formations were deposited (Bolle et al., 1999). In the El Garia Formation and the Ousselat Member of the Metlaoui Group in the Ypresian, nummulitic banks accumulated on the middle to outer shelf across central and northwestern Tunisia (Moody, 1987; Zaier et al., 1998; Loucks et al., 1998). The Ypresian carbonate ramp consists of elongate nummulitic banks, running parallel to the paleoshoreline and shows no patch reef-like bodies (Moody, 1987).

\subsubsection{Western High Atlas (Morocco; $26^{\circ} \mathrm{N}$, locality 15 , Figs. 4, 5)}

The Paleocene and lower Eocene of Morocco contain carbonate to phosphate rocks deposited in small and narrow basins. The carbonate rocks are characterized by oyster-reefs, bryozoans and coralline algae mud mounds and occasionally solitary corals. Echinoids probably thrived around the wave base. Coralgal reefs or larger foraminifera (alveolinids, nummulitids) have not been found (Herbig, 1986; Trappe, 1991, 1992). The absence of coral reefs and larger foraminifera in the early Paleogene make this setting exceptional. The reason for this exceptional situation was probably that during the early Paleogene cool, phosphate-rich water, upwelling from the Atlantic prevented organisms adapted to nutrient-poor and warm environments from settling on this continental margin (Herbig, 1986).

\subsection{Low paleolatitudes (below $20^{\circ}$ )}

\subsubsection{Galala Mountains (Egypt; $20^{\circ} \mathrm{N}$, locality 3, Figs. 4, 5)}

The Maastrichtian-lower Eocene deposits of a carbonate platform margin-to-basin transect in the Galala Mountains (approximately $200 \mathrm{~km}$ SE of Cairo on the western side of the Gulf of Suez) exhibit excellently exposed outcrops across the upper Paleocene to lower Eocene. Over 20 sections have been studied during the last years with respect to lithostratigraphy and paleogeography (Scheibner et al. 2001a), biostratigraphy (Marzouk and Scheibner, 2003; Scheibner and Speijer, in press), ostracode biogeography (Morsi and Scheibner, in press) and platform evolution (Kuss et al., 2000; Scheibner et al., 2000, 2001b, 2003a,b).

This well studied platform margin-to-basin transect serves as the reference area for a recalibration of Paleocene to lower Eocene shallow-water and deep-water biozonations (Scheibner et al., 2005; Scheibner and Speijer, in press; Fig. 3). Information on inner platform deposits in this region is unfortunately scarce due to post-depositional erosion and inaccessible outcrops (mine fields). Scheibner et al. (2003a) subdivided the Paleocene succession into five platform stages (A-E; Fig. 7). Maastrichtian to lower Paleocene hemipelagic sediments characterize platform stages A and B. In the following the three upper Paleocene platform stages $C$ to $E$ are summarized and a lower Eocene platform stage $\mathrm{F}$ is established.
3.3.1.1. Platform stage $C$. The progradation of the Paleogene platform started with platform stage $C$ after a drop in sea level (Scheibner et al., 2003a). After the initiation of the first small debris flows, coralgal patch reefs formed at the carbonate platform margin, while further basinwards massive beds of reef debris accumulated. During this first progradation the lower slope and the toe-of-slope are characterized by debris flows and calciturbidites, respectively (Fig. 7). The clasts within the debris flows at the lower slope originated from all platform areas including the inner platform and therefore allowed a reconstruction of the various depositional settings of the whole carbonate platform (Scheibner et al., 2000). The fossil assemblages indicate deposition during SBZ3 of this early progradation phase. According to Scheibner et al. (2003a) the relative sea-level fall that initiated the progradation of the platform was probably caused by a combination of tectonic activity and a eustatic sea-level fall (sequence Th-1 of Haq et al., 1987 and Hardenbol et al., 1998).

3.3.1.2. Platform stage D. This platform stage represents the second progradational phase and is characterized by a basinward shift of the coralgal patch reefs and debris flows and calciturbidites on the lower slope to toe-of-slope. Similar to platform stage $C$ the fossil assemblages suggest deposition during SBZ3 (Scheibner et al., 2003a).

3.3.1.3. Platform stage $E$. During the retrogradational platform stage E the coralgal patch reefs at the outer carbonate platform were overlain by mud-dominated lithologies of the upper slope and by larger foraminiferal shoals of nummulitids (e.g. Ranikothalia spp.) and Miscellanea spp. This retrogradation is also indicated by a decrease of debris-flow deposits on the lower slope and by a decrease in the amount of calciturbidites arriving at the toe-of-slope. The coralgal patch reefs probably shifted landwards for a short period but must have become quite rare and finally disappeared from this platform, as fragments of corals are absent in the debris flows at the lower slope, whereas inner platform organisms are still present. The fossil assemblages with large Miscellanea spp., Ranikothalia spp., glomalveolinids and Hottingerina lukasi attribute platform stage E to SBZ4.

3.3.1.4. Platform stage $F$. This platform stage is newly introduced here, as Scheibner et al. (2003a) only discussed the Paleocene platform evolution. The base of platform stage $\mathrm{F}$ coincides with the carbon isotopic excursion and thus marks the P/E boundary. The most prominent components of platform stage $\mathrm{F}$ deposits are true alveolinids, orbitolitids and nummulitids (Nummulites spp, Assilina spp.) while larger foraminifera of platform stage E (Miscellanea spp., Ranikothalia spp.) and other foraminifera indicative of SBZ4 (e.g. H. lukasi) are absent. Fragments of solitary corals rarely occur. The alveolinids (A. vredenburgi, A. ellipsoidalis, A. pasticillata) are characteristic for SBZ5/6 (Scheibner et al., 2005; Scheibner and Speijer, in press). SBZ5 and SBZ6 are combined in this study and not separated, because index species of both biozones occur together. This co-occurrence of index forms is not related to redeposition but probably to an extended lower range of index species from SBZ6 or an extended upper range of index species from SBZ5. Similar deviations from the shallow benthic zonation of Serra-Kiel et al. (1998) are described from sections of central Turkey (Özgen-Erdem et al., 2007).

\subsubsection{Sirte Basin (Libya; $20^{\circ} \mathrm{N}$, locality 9, Figs. 4, 5)}

The Sirte basin is one of the major oil production areas in the world and its main reservoir rocks are located in the Paleocene (Ahlbrandt, 2001). Although this time interval has been intensively studied by various authors regarding the structure of the reservoir rocks (Terry and Williams, 1969; Bebout and Pendexter, 1975; Brady et al., 1980; MacGregor and Moody, 1998; Spring and Hansen, 1998; Ahlbrandt, 2001) surprisingly little information is given on the biostratigraphy. 


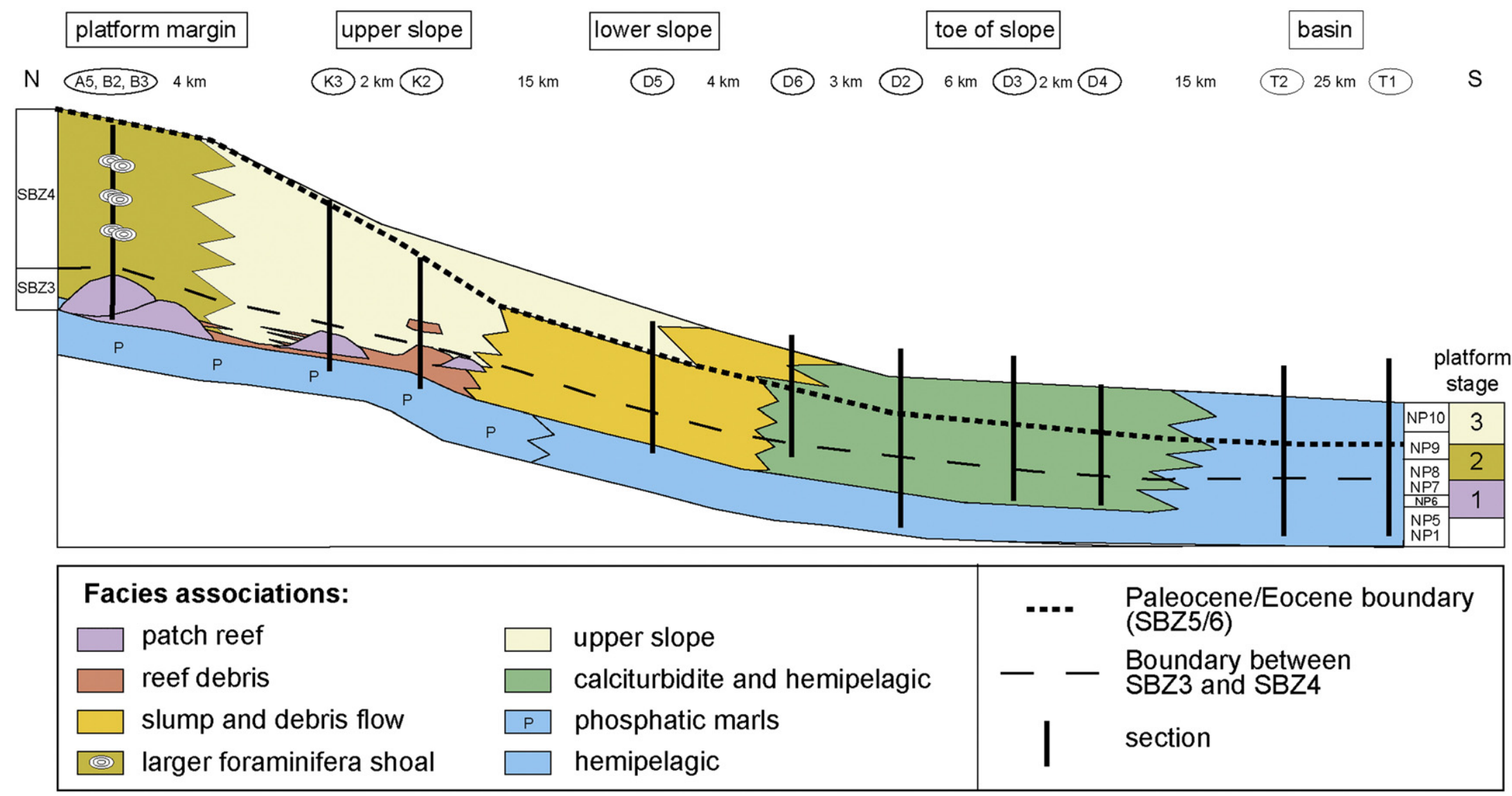

Fig. 7. Platform-basin transect of the Paleocene to lower Eocene in the Galala Mountains (Egypt) with platform stages (after Scheibner and Speijer, in press). 
This region is one of the most difficult to extract biostratigraphic information from, as the authors are mainly dealing with generalizations when speaking of larger foraminifers, and thus making it difficult to differentiate even between Paleocene and Eocene larger benthic assemblages. These authors refer to "large benthic foraminifers", mentioning Nummulites but probably mean nummulitids and not true Nummulites, and their alveolinids are probably mainly glomalveolinids, as can be inferred from the rare thin section images. Therefore our age assignments have to be treated with great caution.

In the Sirte Basin in Libya several upper Paleocene coralgal bioherms have been described (Terry and Williams, 1969; Bebout and Pendexter, 1975; Brady et al., 1980). These bioherms were drowned at the end of the Paleocene and covered by hemipelagic marls, shales and limestones. It is uncertain, whether reef growth reached up to the end of the Paleocene, as larger foraminiferal index species are not mentioned. Terry and Williams (1969) mentioned large "Nummulites" and probably refer to large nummulitids, which would indicate an age of SBZ3 or SBZ4 or younger, as "large" nummulitids occur for the first time in larger quantities in SBZ3. Mresah (1993) described two shallowing-upward platform cycles from other parts of the Sirte Basin, both being dominated by larger foraminifera (Alveolina and nummulitids). Although the alveolinids found in the second interval range in size to $>2.5 \mathrm{~mm}$, which is the lower size range for true Alveolina sp. and would be at the very upper limit of the size range of Glomalveolina sp., the second cycle probably still belongs to the Paleocene and can be compared with the deposits described by Terry and Williams (1969). The overlying shales, marls and evaporates of the Kheir and Gir Formations are regarded as lower Eocene (MacGregor and Moody, 1998; Spring and Hansen, 1998).

In summary, coral reefs probably play an important role in one part of the Sirte Basin at least up to SBZ3, maybe also up to SBZ4, whereas in contemporaneous successions in other parts of the Sirte Basin larger foraminifera dominate.

\subsubsection{Western Desert (Egypt; $19^{\circ} \mathrm{N}$, locality 10, Figs. 4, 5)}

In the Western Desert (Kharga-, Farafra-, Dakhla Oasis, central Egypt), studies focused on the paleoecology of corals (Schuster, 1996), benthic foraminiferal paleoecology (Wielandt, 1996) and Cretaceous to Cenozoic stratigraphy (Barthel and Herrmann-Degen, 1981). In southern Egypt (Bir Abu El-Husein area) Schroeder (1986) focused on diagenesis in Paleocene corals. According to Schuster (1996) coral reefs are found mainly in the Danian of the Abu Tartur Plateau (Kharga Oasis), while in the Selandian, Thanetian and Ilerdian only solitary corals are encountered. Rhodoliths and algal buildups replaced the coral reef growth in this area, which was related to deepening or increased nutrient supply (Schuster, 1996). The small coral knobs in southern Egypt are located at the top of the Kurkur Formation within the Selandian (Schroeder, 1986). Barthel and Herrmann-Degen (1981) correlate a chain of small coral patch reefs in the Peak Hill Member (lagoonal equivalent of the Tarawan Formation) with the coral reefs in the Sirte Basin (Terry and Williams, 1969) and attribute it to the Thanetian, which can be correlated with SBZ3 to SBZ4. During the uppermost Paleocene to earliest Eocene, marls and shales of the Esna Formation were deposited all over central Egypt. Occasionally these marls contain lenses of redeposited nummulitids (LeRoy, 1953; Wielandt, 1996) and macroids (agglomerates) formed by the Acervulina ogormani (Wielandt, 1996). The subsequent lower Eocene (SBZ6 indicated by A. ellipsoidalis) of the Farafra Formation is dominated by larger foraminifera accumulations (alveolinids and nummulitids), although occasionally also solitary corals are found (Barthel and Herrmann-Degen, 1981; Wielandt, 1996). In the highest parts of the Farafra Formation (SBZ6) coral biostromes are found. Recapitulating it is shown that in the Western Desert corals dominated platform assemblages in the Danian to Selandian and partly up to SBZ3 or SBZ4 (Barthel and Herrmann-Degen, 1981), although most of the upper Thanetian is covered by the open marine limestones of the
Tarawan Formation, an unfavorable environment for coral growth. In SBZ5/6 larger foraminifera become the dominant organisms.

\subsubsection{Oman $\left(12^{\circ} \mathrm{N}\right.$, locality 11 , Figs. 4,5$)$}

Racz (1979) investigated the Paleocene carbonates of the Umm er Radhuma Formation in Oman, although the mentioned larger foraminifera (Alveolina s.s. and nummulitids) suggest a stratigraphic range of at least Paleocene to early Eocene. The three mentioned biostratigraphic units Daviesinea Zone, Miscellanea-Distichoplax Zone and Nummulites-Alveolina Zone can be roughly assigned to SBZ3, SBZ4 and early Eocene, respectively. Calcareous algae and larger foraminifera are the prominent fossil components, while coral, gastropod and brachiopod fragments occur only locally (Racz, 1979). The "reef" facies in the investigated interval is composed of oncoids, constructed mainly by red algae, predominantly Ethelia/Polystrata alba. The upper part of the central and north Oman Jafnayn Formation (time equivalent of the Umm er Radhuma Formation) can be attributed to the early Eocene and consists of horizons of alveolinid foraminifera or rhodolithic algal nodules and occasionally coarse coral debris (Nolan et al., 1990). Summarizing it can be said that coral reefs were absent in the Paleocene of Oman, potentially replaced by oncoids, while larger foraminifera dominated the late Paleocene to early Eocene.

\subsubsection{Tibet $\left(5^{\circ} \mathrm{N}\right.$, locality 12 , Figs. 4,5$)$}

In Tibet, upper Paleocene to lower Eocene deposits (SBZ3-SBZ6) are dominated by larger foraminifera (Willems, 1993; Willems and Zhang, 1993a,b; Willems et al., 1996; Zhou et al., 1997; Wan et al., 2002). The Thanetian is characterized by Miscellanea spp., Ranikothalia spp., Discocyclina spp. and rotaliids while the Ilerdian is dominated by Alveolina spp., Opertorbitolites spp., Orbitolites spp. and Nummulites spp. Fragments and completely preserved solitary and colonial corals only occur subordinately in the first two members of the upper Tibetan Paleocene/lower Eocene Zhepure Shan Formation, where they often are encrusted by red algae or form the nuclei of rhodoids. The Zhepure Shan Formation starts in the middle Paleocene ( $M$. angulata zone/P3) and members 1 and 2 can be roughly compared to SBZ2 and SBZ3. However, larger coral reef complexes, dominantly composed of corals are not encountered (Willems, 1993).

\subsubsection{NW India, Pakistan ( $5^{\circ} \mathrm{N}$, locality 17 , Figs. 4,5$)$}

The Paleocene-Ypresian deposits in this area can be subdivided into the Ranikot and Laki Formations, respectively. According to Sahni and Kumar (1974) the Ranikot fauna of western India is more closely related to that of the Mediterranean and Tibet than that of northeastern India (see Section 3.3.7). Several coral reefs thrived during the Paleocene along the western border of the Indian subcontinent, while they retreated during the Eocene to the north and have been reduced to a single locality (Sahni and Kumar, 1974). A more precise timing for the reef growth in the Paleocene and the northern retreat of the coral reefs is not possible as Sahni and Kumar (1974) do not provide any marker fossils. The Paleocene Ranikot foraminiferal fauna in the India-Pakistan-Burma area is remarkably distinct in comparison with the overlying lower Eocene Laki fauna (Nagappa, 1959). Miscellanea and Ranikothalia are restricted to the Paleocene, while true Nummulites are rare or even absent in the Ranikot, but substitute Ranikothalia in the Eocene. According to Hottinger (1971) and Jauhri (1998) the uppermost Ranikot can be attributed to the Ilerdian because of the presence of $A$. vredenburgi, the marker fossil for SBZ5. If correct, this would imply that the occurrences of Miscellanea and Ranikothalia in this area are not restricted to the Paleocene but continue into the lowermost Eocene (SBZ5-SBZ6?).

\footnotetext{
3.3.7. Shillong Plateau (NE India $5^{\circ} \mathrm{S}$, locality 13, Figs. 4, 5)

Larger foraminifera dominate the Paleocene to Eocene successions of the Sylhet Limestone Group (Lakadong, Umlatdoh, Prang Formation)
} 
in NE India, which originally has been grouped as "Nummulitic Series" (Jauhri, 1994; Jauhri and Agarwal, 2001). Jauhri (1994) subdivided the limestones of the Lakadong Formation into three distinct units with characteristic microfossil associations. The rotaliid-miliolid association is characterized by Miscellanea spp., Aberisphaera and rotaliids and may be related to SBZ2 and SBZ3. The second G. primaeva, Distichoplax biserialis association can be undoubtedly related to SBZ3SBZ4 as it is characterized by the marker fossil of SBZ3 (G. primaeva) and SBZ4 (G. levis; Jauhri, 1998). Corals have not been reported from the Paleocene part of the section.

The third Discocyclina and Ranikothalia association correlates with the lower Ilerdian (SBZ5-SBZ6?), identified by the presence A. vredenburgi, the marker fossil of SBZ5, which in NE India co-occurs with Miscellanea miscella and Ranikothalia nuttalli (Jauhri, 1994, 1996, 1998; Jauhri et al., 2006). This most eastern Tethyan area is of special interest for the confinement of biogeoprovinces, as typical lowermost Ilerdian larger foraminifera genera, like Alveolina s.s. or Nummulites are very rare or do not occur. These genera do occur for the first time in the overlying Umlatdoh Limestone (Jauhri, 1996).

Within the Lakadong Formation corals have been found only occasionally in the rocks of the third foraminiferal association, although important coral reefs or deposition of rock-forming coral deposits are not reported (Jauhri and Agarwal, 2001; Jauhri et al., 2006). Furthermore, the encrusting foraminifera Solenomeris (Acervulina), considered as coralline algae, is described only from the upper unit (Misra et al., 2002). The Lakadong Formation correlates with the Ranikot Formation in Pakistan whereas the Umlatdoh Formation correlates with the Laki Formation.

\subsubsection{NW Somalia $\left(0^{\circ}\right.$, locality 14 , Figs. 4,5$)$}

Carbone et al. (1993) analyzed the Paleocene-lower Eocene carbonates of the Auradu Limestone Formation (corresponding to the Umm er Radhuma Formation of the Arabic peninsula) in NW Somalia, which is characterized by larger foraminifera (Lockhartia spp., Sakesaria spp., Miscellanea spp., Alveolina spp., Nummulites spp.) associated with dasycladalean algae, corals, mollusks, bryozoans, brachiopods, and echinoids. "The Auradu coral assemblages consist mostly of small subspherical or phaceloid colonies, while solitary forms are rare" (Carbone et al., 1993). The majority of the studied coral colonies have been collected from the lower part of the Auradu Formation, suggesting a Thanetian age. A more precise age assignment, however, is not possible, i.e. it is not clear whether the coral colonies are restricted to SBZ3 or thrived up to SBZ4.

\subsection{Tethyan platform evolution}

In the following chapter, early Paleogene Tethyan platform evolution is summarized and a model for Tethyan-wide platform stages is presented. In this paper we use the nomenclature for the platform stages developed by Scheibner et al. (2005) in the Galala Mountains (Egypt; Fig. 2). The Paleocene-Eocene time interval from SBZ3-SBZ5/6 in the Tethyan realm can be subdivided into three platform stages, which are characterized by different facies types and dominant organisms. The platform stages are best observed at the carbonate platform margin and the slope, as the characteristic coralgal reefs thrive best in these platform settings or can be observed in shedded deposits. In contrast to these distal platform settings, the more proximal inner platform deposits are dominated by foraminiferal facies and subordinate smaller coral patch reefs or localized coral occurrences. With one exception (Morocco), available data of all 17 investigated platforms fit into the threefold stage subdivision proposed here.

In this study we only investigate the changes in the Tethyan carbonate platform evolution from late Paleocene ( $59 \mathrm{Ma}$ ) to the earliest Eocene (55 Ma). Although several studies focused on early Paleocene evolution of individual platform systems, e.g. studies on intensive reef growth and calcareous red algae in the Pyrenees (Baceta et al., 2005;
Aguirre et al., 2007) and Maiella platform (Vecsei and Moussavian, 1997), our review is the first to document overall systematic developments of Tethyan platforms in this time interval.

\subsubsection{Platform stage I (58.9-56.2 Ma; coralgal platform)}

The onset of the first platform stage coincides with the most prominent Paleocene eustatic sea-level fall (58.9 Ma; Hardenbol et al., 1998 ) and ends very close to the SBZ3/SBZ4 boundary (56.2 Ma). This platform stage is dominated at all paleolatitudes by colonial and solitary corals and encrusting organisms (mainly algae) that thrived at the platform margin (Fig. 6), while the inner platform is composed of shallow-water limestones with miliolids, rotaliids and algae (dasycladalean, solitaire red algae). The only exception of this trend are the lowest paleolatitudes investigated in this study, NE India and Tibet $\left(5^{\circ}\right)$, where larger foraminifera already dominated over coral reefs during this time interval. Platform stage I corresponds with sequence 2.1 in Spain (Pujalte et al., 1993), and with platform stages C and D in Egypt (Scheibner et al., 2003a).

\subsubsection{Platform stage II (56.2-55.5 Ma; coralgal and first larger foraminiferal platform)}

The second platform stage is restricted to SBZ4 and terminates at the P/E boundary (55.5 Ma; Scheibner et al., 2005). This platform stage has a transitional position between platform stage I and platform stage III. In low latitudes (below $20^{\circ}$ ) it is characterized by the occurrence of the first larger foraminiferal shoals, composed of Miscellanea and $R a-$ nikothalia, while coralgal reef facies, apart from scarce coral debris are absent (e.g. Egypt). At this time, the middle latitudes (above $30^{\circ}$ ), with the exception of the Pyrenean area, are still characterized by coralgal facies. Overall, larger foraminifera (Assilina) dominated the Pyrenean area, although corals also contribute to carbonate accumulation (Scheibner et al., 2007). The inner platform facies of platform stage II is somewhat similar to the first platform stage. Platform stage II corresponds with sequence Th-2 in Spain (Payros et al., 2000) and platform stage E in Egypt (Scheibner et al., 2003a).

\subsubsection{Platform stage III (55.5- ?55.0 Ma; 2. larger foraminiferal platform)}

With the onset of the Eocene (55.5 Ma; SBZ5) the third and most prominent platform stage developed and similar to platform stage I it shows no strong latitudinal differentiation with respect to its dominant organisms. As the lower Eocene strata in the reference area in Egypt have not been entirely studied, we refrain from appointing a distinct termination of platform stage III (Fig. 7). This second larger foraminifera-dominated platform marks the beginning of the rapid radiation and proliferation of alveolinids and nummulitids. During this platform stage the inner platform to outer platform/slope transect can be subdivided on the basis of the paleobathymetric distribution of larger foraminifera, ranging from orbitolitids and alveolinids in the proximal part of the platform over nummulitids (Nummulites, Assilina, Operculina) in the middle part of the platform to discocyclinids in the distal part of the platform. The lower Eocene deposits are either nearly barren of corals (Galala/ Egypt) or only contain solitary corals or, rarely, small isolated patch reefs (e.g. Pyrenees, Eichenseer and Luterbacher, 1992). In some areas (e.g. Pyrenees) the encrusting foraminifera Acervulina built km-sized reefs (Plaziat and Perrin, 1992). The third platform stage coincides with the lower part of sequence 2.3 in Spain (Pujalte et al., 1993) and platform stage F in Egypt (confer Scheibner et al., 2003a). The only exception to this general pattern is NE India, the most eastern Tethyan area, in which larger foraminifera of the first assemblage (Stage 2) still thrive at the beginning of platform stage III.

Summarizing it can be said that the evolution from the first platform stage, dominated by coral reefs, to the second transitional platform stage, characterized by larger foraminifera in low latitudes and coral reefs in middle latitudes to the third platform stage, which is dominated by larger foraminifera in all latitudes, is strongly 
dependent on the organism distribution pattern of the two most important groups, corals and larger foraminifera. In the following chapters we will discuss the response of both organism groups to evolutionary and external forces to decode the late Paleocene to early Eocene Tethyan distribution patterns of coral reefs and larger foraminifera.

\section{Climate proxies in the early Paleogene}

This chapter deals with the absolute and latitudinal changes of climate proxies (temperature, $\mathrm{CO}_{2}$, precipitation; Figs. 2 and 8 ) and the efforts of modeling early Paleogene climate to reproduce the results of these proxies. Furthermore, we present a short overview on the trophic resource regime (Hallock, 1987) in the oceans within that time interval. The variations within these climate proxies are among other things important to explain the distribution patterns of the major organism groups within the shallow-water realm during this time period, corals and larger foraminifera. The coral and larger foraminifera distribution patterns (Sections 5 and 6) in turn are responsible for the proposed three-step platform evolution and the latitudinal gradients of the platforms (Section 7).

\subsection{Absolute and latitudinal temperature changes:}

The late Cretaceous to early Paleogene is characterized by warm generally ice-free conditions (Zachos et al., 1993; Sloan and Thomas, 1998), although occasionally transient glaciations may have occurred in inland Antarctica, to account for sea-level changes up to about $30 \mathrm{~m}$ (Speijer and Morsi, 2002; Miller et al., 2005a,b). These warm conditions culminated into the early Eocene Climatic Optimum (EECO, Zachos et al., 2001). The overall warming trend in the Paleogene was interrupted only around $60 \mathrm{Ma}$ to $58 \mathrm{Ma}$, when a low-amplitude short time cooling occurred (Zachos et al., 2001; Fig. 2). Characteristic for the early Paleogene warmth is the so-called "equable" climate (Sloan and Barron, 1990; Greenwood and Wing, 1995). This concept with only slightly elevated global mean annual temperatures (MAT; $17{ }^{\circ} \mathrm{C}-21{ }^{\circ} \mathrm{C}$, Sewall et al., 2004) in comparison of today's global MAT $\left(14^{\circ}-15^{\circ}\right.$, Hansen et al., 2007) was frequently discussed in the 1990s. Until recently, this "equable" climate was thought to have resulted mainly from a temperature increase at higher latitudes, since low latitude temperatures seemed to have remained unaffected or were even cooler in comparison with temperature data of today (e.g. Zachos, 1994). However, there is increasing evidence that seasurface temperatures at low latitudes in the early Paleogene have been warmer than established previously by proxy data, like $\delta^{18} \mathrm{O}$-studies of planktic foraminifera (Pearson et al., 2001, 2007; Fig. 2). New data may also indicate a tropical warming trend from the Paleocene to the earliest Eocene (Pearson et al., 2007). On the basis of exceptionally well-preserved planktic foraminifera from Tanzania, Pearson et al. (2001, 2007) recalculated late Cretaceous and Eocene tropical seasurface temperatures to be at least $28^{\circ}-32{ }^{\circ} \mathrm{C}$ in contrast to the previous estimates of $20^{\circ}-26{ }^{\circ} \mathrm{C}$ for the Eocene (Zachos, 1994; in comparison, today's tropical temperatures range between $25^{\circ}$ and $27^{\circ} \mathrm{C}$, Kump, 2001). Mg/Ca-based temperatures for the Late Paleocene were estimated at $31{ }^{\circ} \mathrm{C}$, while the early Eocene shows the highest temperatures of about $33^{\circ}-34^{\circ}$ (Tripati et al., 2003; Fig. 2). Other proxies like mollusk oxygen isotope values also hint to higher temperatures than previously established by $\delta^{18} \mathrm{O}$-studies of planktic foraminifera (Kobashi et al., 2001). Further SST reconstructions of the Cretaceous, largely based on the $\mathrm{TEX}_{86}$ temperature proxy, suggest that the tropics could have been even warmer and SST may have reached up to $40{ }^{\circ} \mathrm{C}$ (Schouten et al., 2003; Bice et al., 2006; Forster et al., 2007; Weijers et al., 2007).

High temperatures at middle latitudes are supported by a broad latitudinal distribution of temperature-sensitive organisms such as larger foraminifera, corals, mangroves, palms, and reptiles (Adams et al., 1990; Hallock, 2000; Pearson et al., 2001). A temperature rise in the middle latitudes is also supported by widening of the tropical reef zone and zone of shallow-marine platform growth (Kiessling, 2001; Philip, 2003). In the late Paleocene and Eocene coral reefs occur up to $46^{\circ} \mathrm{N}$ in comparison to $34^{\circ} \mathrm{N}$ of today's coral reef distribution (Kiessling, 2001). Reef-building corals of the genus Acropora were found at even higher paleolatitudes $\left(51^{\circ} \mathrm{N}\right)$ in the middle Eocene of England (Wallace and Rosen, 2006). Low-latitude warming is indicated by changes in tropical vegetation of northern South America (Rull, 1999; Jaramillo and Dilcher, 2000; Jaramillo, 2002) while a warming in high latitudes is indicated by fossil wood of Antarctica (Francis and Poole, 2002). Clay mineralogical changes provide indirect evidence for warming in the Tethyan realm, which was characterized by a strong increase in kaolinite pointing to an episode of warmth and humidity during the PETM (Bolle and Adatte, 2001; Fig. 2).

The main reason for the warm climate during the late Paleocene to early Eocene could have been enhanced concentrations of greenhouse gases like $\mathrm{CO}_{2}$ and methane (Pagani et al., 2006a). Increasing sea floor hydrothermal activity might have been the source for these elevated concentrations (Rea et al., 1990). Alternatively, volcanic activity in the North Atlantic igneous province, which took place in two phases between $60 \mathrm{Ma}$ to $62 \mathrm{Ma}$ and $57 \mathrm{Ma}$ to $58 \mathrm{Ma}$ (Svensen et al., 2004; Thomas and Bralower, 2005), could have been involved. The oxidation of organic-rich sediments during the India-Asia collision may also have acted as a driving mechanism for enhanced $\mathrm{CO}_{2}$ concentrations (Beck et al., 1998; Thomas et al., 2000). Finally, methane release from wetlands and methane dissociation during the PETM and similar subsequent events from sea floor gas hydrate reservoirs are also considered as important contributors for increase in greenhouse gases (Sloan et al., 1992; Pearson and Palmer, 2000; Pancost et al., 2007).

During the warm Paleogene interval possibly several hyperthermals occurred, the most prominent being the Paleocene-Eocene Thermal Maximum (PETM) with a temperature rise in the deep sea of about $5-6{ }^{\circ} \mathrm{C}$ (Zachos et al., 2001). Sea-surface temperatures during the PETM increased in high latitudes by $5^{\circ}$ to $8^{\circ}$ and in low latitudes by $4^{\circ}$ to $5^{\circ}$ (Zachos et al., 2003; Tripati and Elderfield, 2004; Sluijs et al., 2006, 2007; Fig. 2) which is in agreement with climate modeling studies and geological observations (Sloan and Thomas, 1998). Furthermore, also in a coastal marine setting at the New Jersey continental margin, USA (middle paleolatitude: $35-37^{\circ} \mathrm{N}$ ), Zachos et al. (2006) documented a minimum warming of $8{ }^{\circ} \mathrm{C}$ during the PETM, with peak temperatures of $33{ }^{\circ} \mathrm{C}$ based on $\mathrm{TEX}_{86}$ and isotope data. Similarly, floral composition in Wyoming (USA) suggests a temperature rise of ca. $5{ }^{\circ} \mathrm{C}$ (Wing et al., 2005). The results of a recent drilling expedition at the Lomonosov Ridge at the central Arctic Ocean reveals an increase of summer sea-surface temperatures from $18{ }^{\circ} \mathrm{C}$ to over $23{ }^{\circ} \mathrm{C}$ (Sluijs et al., 2006, 2008; Moran et al., 2006; Weijers et al., 2007). During this time interval the warm water (subtropical) dinoflagellate Apectodinium dominated the fossil record (Sluijs et al., 2006). A cyclostratigraphic analysis (Norris and Röhl, 1999) suggests that two-thirds of the $\delta^{13} \mathrm{C}$ shift occurred during a time period of just a few thousand years or less and probably the initial warming occurred during a similar period.

Until recently, methane dissociation was discussed as the main trigger for the PETM (Dickens et al., 1995; Bains et al., 1999; Katz et al., 2001; Thomas et al., 2002). Recent investigations by Zachos et al. (2005) and Pagani et al. (2006a) indicate that the total input of carbon, released from gas hydrates is not large enough to produce the relevant amount of carbon to shoal the CCD by more than $2 \mathrm{~km}$. Furthermore, the terrestrial plant-carbon isotope excursion is higher than those of marine carbonates, which implies, if no other factors caused this excursion (Bowen et al., 2004), an even higher input of carbon than previously suggested (Pagani et al., 2006b). Because the methane hypothesis is not able to completely explain all observed data, several other hypotheses were established, either to work as stand-alone mechanisms or in combination with the methane release hypothesis. 
Extensive global wild fires that resulted from a shift toward drier climates could have burnt the Paleocene peat lands resulting in rapid oxidation (Kurtz et al., 2003; Collinson et al., 2003, 2007; Higgins and Schrag, 2006). A similar rapid oxidation of organic mass could be triggered by the exposure of the extensive shallow epicontinental seaways (Higgins and Schrag, 2006). Igneous activity in the northern Atlantic, resulting in magma intrusion in organic-rich sediments and in a regional uplift are also considered as a source of negative $\delta^{13} \mathrm{C}$ (Svensen et al., 2004; Maclennan and Jones, 2006; Higgins and Schrag, 2006; Storey et al., 2007). A further source of negative $\delta^{13} \mathrm{C}$ could result from an impact of a carbon-rich comet (Kent et al., 2003; Cramer and Kent, 2005).

\section{2. $\mathrm{CO}_{2}$}

$\mathrm{CO}_{2}$ is an important greenhouse gas and therefore considered to be a key element of climate change. The rise from pre-industrial concentrations (280 ppm) to modern values (380 ppm) and is associated with a $1{ }^{\circ} \mathrm{C}$ rise in global averaged temperature (Royer, 2003). Recent modeling of atmospheric $\mathrm{CO}_{2}$ content during the last 420 Million years suggests a climate sensitivity greater than $1.5^{\circ}$ (Royer et al., 2007), with climate sensitivity describing the amount of temperature increase in response to a doubling of atmospheric $\mathrm{CO}_{2}$. The Phanerozoic $\mathrm{CO}_{2}$ curve is in general closely related with temperature, where low $p \mathrm{CO}_{2}$ values correlate with continental glaciations, while high $\mathrm{pCO}_{2}$ values appear to exclude glaciations (Royer, 2006; Fletcher et al., 2008). In contrast to the overall Phanerozoic $\mathrm{CO}_{2}$ /temperature relationship, the early Paleogene is a climatic enigma because of the variability of the $p \mathrm{CO}_{2}$ curve throughout this time interval (Royer, 2006; Pagani et al., 2005). The study of Demicco et al. (2003; Fig. 8) suggests an overall range from $100 \mathrm{ppm}$ to $2500 \mathrm{ppm}$. Furthermore, estimated $p \mathrm{CO}_{2}$ values also vary considerably between methods used (Royer et al., 2001b). Although the estimated absolute concentrations of $\mathrm{pCO}_{2}$ vary among the different studies, most studies suggest peaks at the $\mathrm{P} / \mathrm{E}$ boundary and at the Early Eocene Climatic Optimum, supporting on the one hand the interrelation of temperature and $\mathrm{CO}_{2}$, and on the other hand the temperature highs during these time intervals.

\subsection{Precipitation, runoff and climate}

Precipitation, subsequent continental runoff and thus an increase in supply of nutrients are important parameters controlling organic productivity in the oceans. One indicator of humidity and precipitation is the clay mineral composition of marine sediments, especially the occurrence of kaolinite in low latitudes. An increase in kaolinite is generally associated with warm humid climates (Robert and Chamley, 1991). Clay mineral contents in North and South Atlantic oceanic deposits from late Paleocene to middle Eocene indicate increased humidity and thus continental runoff from low to mid latitudes, while increased evaporation took place in low latitude coastal areas (Robert and Chamley, 1991; Robert and Kennett, 1994; Kelly et al., 2005). These climatic effects culminated during the PETM. Evidence for intensified chemical weathering during the PETM also comes from an osmium isotope excursion from drilling sites in the Indian Ocean and the N Atlantic (Ravizza et al., 2001). Intensified precipitation and subsequent runoff has also been described for the PETM in the Artic (Pagani et al., 2006b). Clay mineral records also support the view that from middle Eocene time onwards global climate generally cooled (Robert and Chamley, 1991).

For the Tethyan region, Bolle et al. (1998, 1999, 2000a,b,c) investigated several areas at the southern Tethyan margin (Tunisia, Egypt, Israel) and northern Tethyan margin (Spain, Kazakhstan) and summarized the Paleogene climatic evolution of the Tethys (Bolle and Adatte, 2001) including additional settings from western Europe (Spain, England). During the early Paleocene the Tethyan region was characterized by a warm and humid climate with high precipitation (Bolle and Adatte, 2001). From the late Paleocene onwards a differentiation within this region occurred. Seasonal climates existed in Egypt, N Tunisia, Spain, Kazakhstan and England, while warm and arid climates are evident in Israel and S Tunisia. The PETM is characterized by warm and humid climate in N Tunisia, Spain and Egypt (Ernst et al., 2006), by warm and arid conditions in Israel and S Tunisia, while in Kazakhstan and England seasonal climate persisted. In the last two settings a warm and humid climate started during the early Eocene. In the Pyrenees, Spain, Schmitz and Pujalte $(2003,2007)$ noticed a dramatic increase in seasonal rain

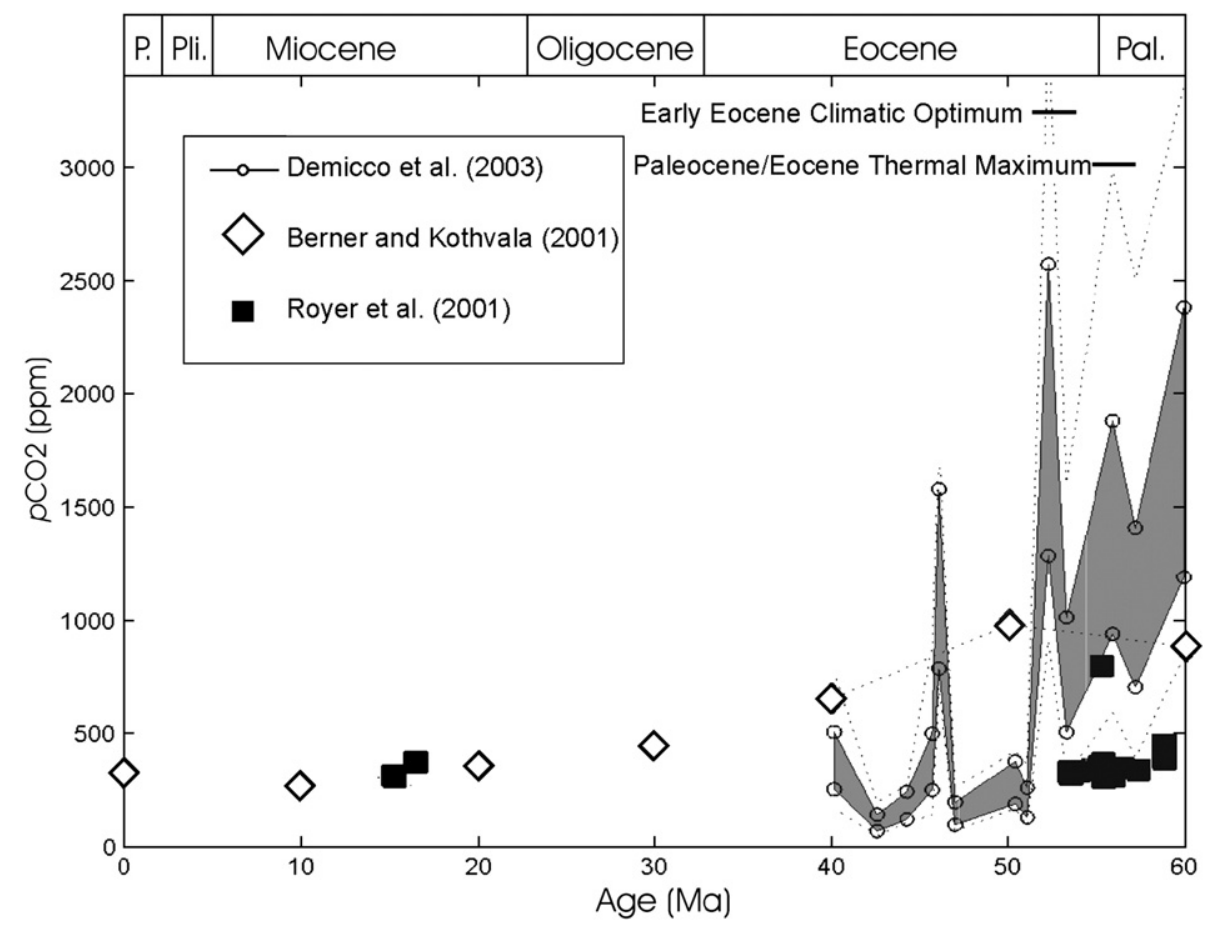

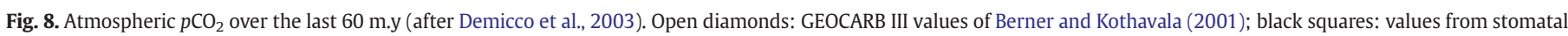
density data of Royer et al. (2001a); open circles: the grey shaded area envelopes two sets of calculated $p \mathrm{CO}_{2}$ values from Demicco et al. (2003). 
and an increased intra-annual humidity gradient during the PETM that resulted in a megafan complex. Summarizing the global climatic situation for the PETM it can be noticed that this interval is characterized by enhanced humidity and thus an intensified hydrologic cycle, resulting in increased terrigenous input in hemipelagic regions, with exceptions in only few areas (Bolle and Adatte, 2001; Pagani et al., 2006b; Giusberti et al., 2007; Zachos et al., 2008). The intensified hydrologic cycle would have brought enhanced nutrients into marginal basins, whereas the open ocean may have remained oligotrophic (Gibbs et al., 2006b), which bears on a discussion of the trophic resource regimes.

\subsection{Trophic resource regime}

Following the concept of Hallock (1987), "The trophic resource continuum (TRC) in euphotic zones of the world's oceans is the spectrum of conditions from the richest runoff and upwelling areas to the most nutrient-deficient subtropical seas." Zooxanthellate organisms, as corals and larger foraminifera, are highly adapted to nutrientdeficient oligotrophic conditions (Hallock, 1988a). If nutrient input in the euphotic zone increases, transparency of the water column will be reduced, which in turn decreases the depth range for organisms relying on photosynthesis. Higher nutrient levels also favor organisms, which either compete with corals (fleshy algae) or destroy them (bioeroders; Hallock and Schlager, 1986; Hallock, 1988a). The development of oligotrophic habitats is maximal under poorly mixed and stable oceanic conditions.

Parallel to the evolution of larger foraminifera at shelf margins, oligotrophic planktic foraminifera as the symbiont-bearing acarininids and morozovellids thrived in the open oceans (Hallock et al., 1991; Boersma et al., 1998; Kelly, 2002; Petrizzo, 2007). The rise of these lineages during the late Paleocene is thought to reflect a transition from a warm, relatively well-mixed early Paleocene ocean to a warmer, poorly mixed global ocean of the late Paleocene to middle Eocene (Boersma et al., 1998). Over this 10 million year period, conditions became optimal for K-strategists as larger foraminifera and morozovellids (Hallock et al., 1991). Nannofossil assemblages at the PETM also indicate oligotrophic conditions in the open ocean (Bralower, 2002; Stoll et al., 2007; Mutterlose et al., 2007), although Mutterlose et al. (2007) pointed out that the trophic status of the equatorial Atlantic cannot be fully determined, as stenotopic taxa provide conflicting evidence.

In contrast to the oligotrophic conditions around the $\mathrm{P} / \mathrm{E}$ boundary postulated by Hallock et al. (1991) and Boersma et al. (1998), productivity in coastal surface waters appears to have increased substantially at and beyond the P/E boundary. Geochemical and biotic proxis can be consulted to document a decrease of oligotrophic conditions and an increase of mesotrophic to eutrophic conditions during the PETM. High productivity can be inferred from black shale deposition in the Tethys (Speijer and Wagner, 2002; Gavrilov et al., 2003), the collapse of the oligotrophic Gavelinella beccariiformis benthic foraminiferal community (Speijer et al., 1997), increased biogenic barium values (Schmitz et al., 1997; Thompson and Schmitz, 1997; Bains et al., 2000; Schmitz, 2000), a widespread bloom of the organic-walled dinoflagellate Apectodinium and the coccolithophorid genus Toweius that resulted from intensified weathering and subsequent nutrient input into marginal basins through increased runoff (Crouch et al., 2001, 2003; Crouch and Brinkhuis, 2005; Stoll and Bains, 2003). In a former shelf setting (New Jersey, USA), oligotrophic nannofossil genera are reduced in abundance, while mesotrophic genera increased due to increased nutrient availability during the PETM (Gibbs et al., 2006b). Intensified weathering is also documented by an increase in kaolinite (Bolle and Adatte, 2001; Ernst et al., 2006), an osmium isotope excursion (Ravizza et al., 2001), and an increase in the rate of hemipelagic sedimentation in the northern Tethys (Egger et al., 2003; Giusberti et al., 2007).

The different opinions on the Paleogene trophic resource regime may originate from the fact that the eutrophic conditions around the
PETM occurred 1) only during a short period and 2) predominantly on the shelf areas due to increased continental weathering and continental runoff (Bralower, 2002). Detailed calcareous nannofossil studies of an open ocean site and a shelf site also hint to productivity variations from locally high productivity areas at the shelves and an overall low productivity at the open oceans (Gibbs et al., 2006b; Jiang and Wise, 2006; Petrizzo, 2007). In this scenario the PETM marks only a perturbation at the shelf margins in the long lasting oligotrophic trend of the Paleogene trophic resource regime. Summarizing it can be said that the PETM is a time of an expanded trophic resource continuum, characterized by regionally intensified eutrophy on the shelf areas and oligotrophy at the open oceans.

\subsection{Early Paleogene climate modeling}

Over the last 15 years researchers have tried to model early Paleogene climate with general circulation model simulations (Sloan and Rea, 1995; Sloan and Thomas, 1998; Huber et al., 2003; Sewall et al., 2004) to match with the "equable" climate proposed by proxy data analyses (mainly $\delta^{18} \mathrm{O}$ of foraminifera). In individual modeling studies different aspects of climate forcing were investigated: El Niño effects (Huber and Caballero, 2003), temperature distribution (Huber and Sloan, 2000; Bice et al., 2000; Sloan et al., 2001), thermohaline circulation (Bice and Marotzke, 2001), polar stratospheric clouds (Sloan and Huber, 2001a), greenhouse gases (Sloan and Rea, 1995; Shellito et al., 2003), sedimentary influx (Bice et al., 1997), and orbital forcing (Sloan and Morrill, 1998; Sloan and Huber, 2001b; Sewall and Sloan, 2004). In most simulations the "equable" climate with increased mean annual temperatures by $2^{\circ}-6^{\circ}$, low vertical and latitudinal seawater temperature changes, warm high latitudes and cool low latitudes could not be reproduced ("cool tropic paradox", the discrepancy between proxy data and modeling studies (D'Hondt and Arthur, 1996)).

Modeling studies used a broad variation of greenhouse gas concentrations to simulate the early Paleogene climate (e.g. Shellito et al., 2003; Huber and Caballero, 2003; Sewall et al., 2004). The models confirm that it is plausible that $\mathrm{CO}_{2}$ levels in the early Paleogene were at least 3 to 4 times higher than the pre-industrial standard (Shellito et al., 2003), but they could not solve the discrepancy between the warm high latitudes and the relatively cool low latitudes. With low $\mathrm{CO}_{2}$ values the relatively cool temperatures (indicated by proxies) of the low latitudes are in correspondence with modeling results, while the high latitudes remain too cold. Models using high $\mathrm{CO}_{2}$ values are in better agreement with proxies from high latitudes, but in these scenarios the low latitudes were much warmer than indicated by proxy data. A possibility to reduce the discrepancy between proxy data and model predictions could be the incorporation of changed global partitioning of the ${ }^{18} \mathrm{O}$ isotopes in the ocean, resulting in a temperature effect, which can be up to $8{ }^{\circ} \mathrm{C}$ in the equator-to-pole gradient (Roche et al., 2006).

Proxy data for the low latitudes would be in the temperature range of the modeled temperatures (Shellito et al., 2003) if recent $\delta^{18} \mathrm{O}$ analyses of pristine planktic foraminifera and $\mathrm{Mg} / \mathrm{Ca}$-based temperature estimates were used. These estimates suggest much warmer temperatures for low latitudes than previously appraised (Pearson et al., 2001, 2007; Tripati et al., 2003; Sexton et al., 2006a). In contrast to the now concordant proxy and modeled temperatures for low latitudes the latest proxy data of the high latitudes (Sluijs et al., 2006, 2008; Weijers et al., 2007) are up to $10{ }^{\circ} \mathrm{C}$ higher than previously modeled (Sewall et al., 2004). Although the model of Sewall et al. (2004) is a fully coupled earth system model with fixed SST's, added for a correction of the heat flux, and was published before the latest proxy temperature estimates for low and high latitudes (Pearson et al., 2007; Sluijs et al., 2006; Weijers et al., 2007), we are using this model to display a possible temperature distribution for the early Paleogene (65 Ma-45 Ma; Fig. 9). The reason for the application of this model in our study is the consistency of the 
modeled temperature distribution maps in the low latitudes with the recent published proxy data for low latitudes. These temperature distribution maps are thought to represent a possible early Paleogene SST distribution for low latitudes, on which we are concentrating in this paper.

Sewall et al. (2004) used elevated greenhouse gas concentrations of $1120 \mathrm{ppm} \mathrm{CO}$ and $700 \mathrm{ppb} \mathrm{CH}$. The tropical SST varies between $25{ }^{\circ} \mathrm{C}$ and $35^{\circ} \mathrm{C}$ in all seasons, while arctic SST have annual average values of $0{ }^{\circ} \mathrm{C}-5{ }^{\circ} \mathrm{C}$ and summer values of up to $7.5{ }^{\circ} \mathrm{C}$ (Fig. 9). The modeled temperatures depend on the $\mathrm{CO}_{2}$ scenario chosen. Further modeling studies are needed to include the warmer high latitude estimates of Sluijs et al. (2006) and Weijers et al. (2007). In the model of Sewall et al. (2004) the Tethyan realm can be subdivided into two provinces, a western province, covering S Europe and N Africa, with annual average temperatures of $>25{ }^{\circ} \mathrm{C}$ and an eastern province, centered around the Indian subcontinent, with $>30^{\circ} \mathrm{C}$ (Fig. 9).
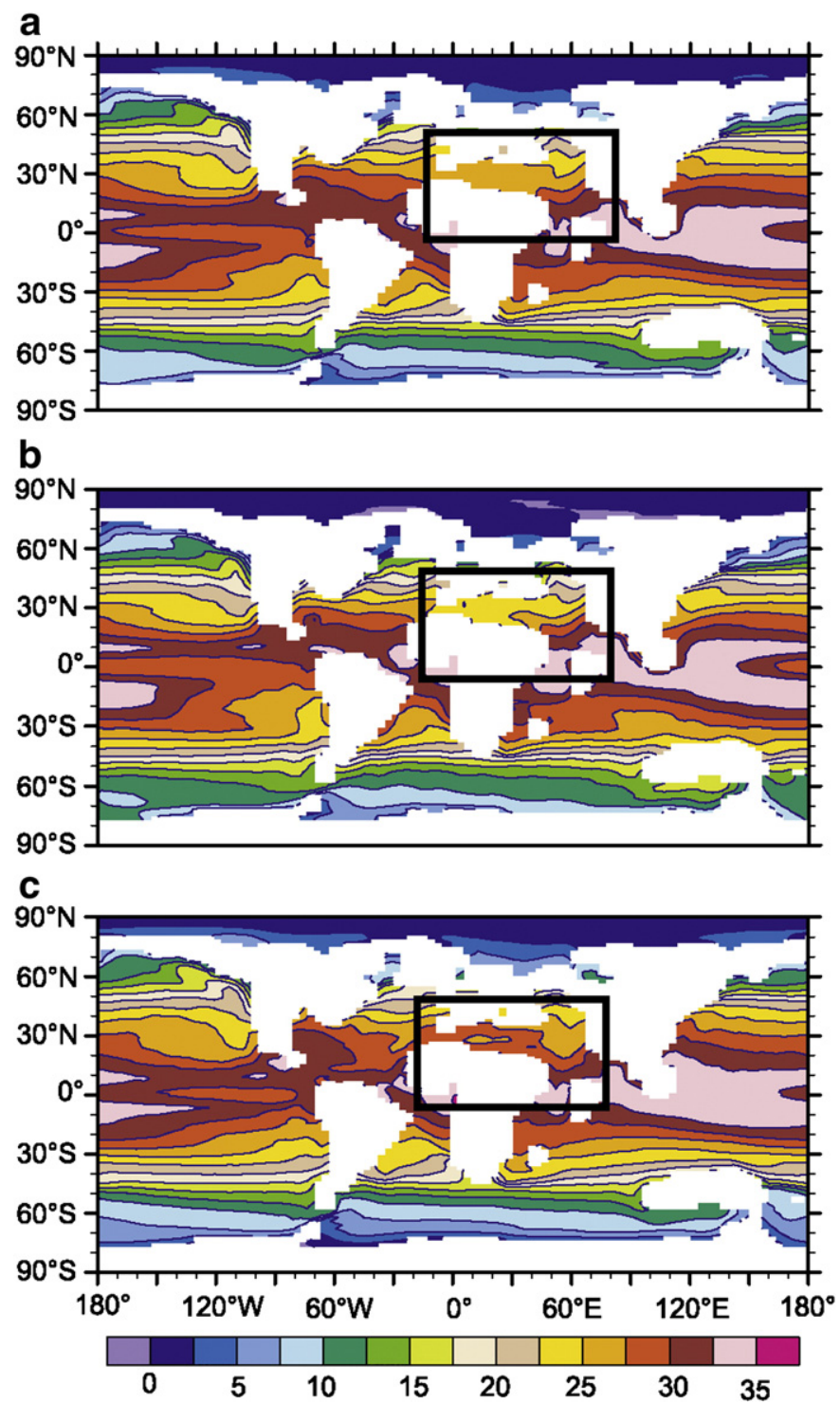

Fig. 9. SST distribution $\left({ }^{\circ} \mathrm{C}\right)$ of the early Paleogene, predicted by the warm arctic case scenario from Sewall et al. (2004): a) annual average, b) December, January, February average, c) June, July, August average.

\section{Parameters controlling coral-distribution patterns}

Corals are highly sensitive to their ambient water quality, particularly temperature, and are therefore considered excellent proxies for climatic change. In the following chapter we first summarize the temperature sensitivity of corals, especially temperature changes connected to El Niño Southern Oscillation events (ENSO). Then the importance of $\mathrm{CO}_{2}$ for calcification of corals is discussed and finally the geochemical composition of seawater with respect to $\mathrm{Mg}$ and $\mathrm{Ca}$ is elaborated. All these parameters controlling recent coral or coral reef growth were strongly debated in recent years and for further information the reader is referred to specialized literature (e.g. Brown, 1997; Hoegh-Guldberg, 1999, 2005, 2007; Wilkinson, 1999; Kleypas et al., 2001; Fitt et al., 2001; Barton and Casey, 2005). In the last chapter the coral distribution of the early Paleogene is presented.

\subsection{Temperature sensitivity of corals}

Today tropical coral reefs occur in shallow seas between $35^{\circ} \mathrm{S}$ and $34^{\circ} \mathrm{N}$ (Kiessling, 2002) and are restricted to areas with temperatures between $18{ }^{\circ} \mathrm{C}$ and $36{ }^{\circ} \mathrm{C}$, with optimum temperatures between $22{ }^{\circ} \mathrm{C}$ and $28{ }^{\circ} \mathrm{C}$ (Wilkinson, 1999). The highest SSTs are recorded for the Arabian Sea with temperatures reaching up to $34{ }^{\circ} \mathrm{C}$. Tropical reefbuilding corals are living at or very close to their upper biological threshold for temperature (Hallock, 2000, 2005; Hallock et al., 2006). Therefore they are very sensitive to slight increases in summer SST and react by symbiont loss, resulting in bleaching of the host coral. Bleaching in corals is a reaction to accelerated stress that is strongly associated with elevated temperature as the main factor. Further causes are high solar irradiance, exposure time to elevated temperatures and disease, as stress appears to lower the coral's resistance to disease (Brown, 1997; Goldberg and Wilkinson, 2004; Harvell et al., 2002; Fitt et al., 2001). Whereas enhanced temperature affects corals, internal and external bioeroders are unaffected and in combination with viruses they can contribute to an accelerated decline of coral reefs (Glynn, 2000; Harvell et al., 2002). Investigations on today's reefs and corals reveal that increases in maximum SST's of about $1{ }^{\circ} \mathrm{C}$ above mean SST's are sufficient to cause bleaching (Hughes et al., 2003; Kleypas et al., 2001).

However, as corals are living in oceans with varying SST, the absolute temperature threshold at which bleaching occurs also varies regionally (Hughes et al., 2003). In the ENSO year 1998 with peaking global average temperature more than $90 \%$ of shallow corals in Indian reefs were killed by warm SST's (Sheppard, 2003) but lethal threshold temperatures varied from $29^{\circ}$ to $34^{\circ}$. That means that most corals in the Arabian Sea survived temperatures that killed 1998 corals elsewhere (Sheppard, 2003) and leads to the conclusion that temperature anomalies within the individual regions of coral reef growth are of higher importance than mere absolute temperature. Bleaching is not only restricted to tropical seas, but can occur at all latitudes. Goldberg and Wilkinson (2004) reported another example of differential temperature threshold values for bleaching in the Mediterranean, when two symbiotic corals bleached, probably as a result of elevated summer temperatures ( $1.2{ }^{\circ} \mathrm{C}$ above summer maximum), although the absolute temperature was only about $22^{\circ} \mathrm{C}$ to $23.9^{\circ} \mathrm{C}$.

These varying upper temperature threshold ranges for coral bleaching from $24{ }^{\circ} \mathrm{C}$ to $34{ }^{\circ} \mathrm{C}$ imply that corals as a group are able to adapt during geologic times to higher temperatures, but the question remains, whether corals can adapt as fast as necessary to counteract rapid temperature rise (Buddemeier et al., 2004). Today, adaptation of corals to higher temperatures seems to be close to the limit, as mortality rates of corals have increased since the 1980s (30\% of corals have disappeared from coral reefs; Hoegh-Guldberg, 2005).

\subsubsection{Corals and El Niño}

El Niño-Southern Oscillation (ENSO) is the combined phenomenon of thermal and circulation changes of the ocean and the atmosphere, 
which has its origin in the central Pacific Ocean (Trenberth, 1997). An El Niño event is inferred when the following applies: If the 5-month running means of sea-surface temperature (SST) anomalies in the Niño 3.4 region $\left(5^{\circ} \mathrm{N}-5^{\circ} \mathrm{S}, 120^{\circ}-170^{\circ} \mathrm{W}\right)$ exceed $0.4^{\circ} \mathrm{C}$ for 6 months or more (Trenberth, 1997). Recent modeling studies suggest a connection between a doubling of the $\mathrm{CO}_{2}$ content and a higher ENSO magnitude (Yeh et al., 2006). Since the 1980s ENSO events intensified (higher temperature anomalies) and worldwide coral bleaching occurred after these events (especially 1983, 1987 and 1998, Glynn, 2000; Fitt et al., 2001; Fig. 8). This bleaching is a reaction to increased anomalous temperatures caused by the ENSO events (Fitt et al., 2001) and is often followed by high mortality and reduced growth rates (Hughes et al., 2003). Current proxy data of ENSO effects in the early Paleogene are as yet insufficient but simulations from a fully coupled circulation model suggest that the temperature anomalies of ENSO are about $60 \%$ greater than current values. Furthermore, these studies suggest a more global effect, with stronger consequences to Europe than today (Huber and Caballero, 2003). These higher temperature anomalies could have led to amplified bleaching and subsequent high coral mortality at low and middle latitudes.

\subsection{Calcification of corals}

$\mathrm{CO}_{2}$ is not only a prominent greenhouse gas and a key player in presently rising temperature (see Section 4.2 about $\mathrm{CO}_{2}$ ) and its consequences for coral growth (see previous Section 5.1), but the amount of $\mathrm{CO}_{2}$ in the seawater also directly controls calcification rates of marine organisms such as reef corals and coralline algae (Gattuso and Buddemeier, 2000; Guinotte et al., 2003) as well as pteropods and cold-water corals (Orr et al., 2005). Besides the amount of $\mathrm{CO}_{2}$, the rate of change is equally important (Caldeira and Wickett, 2003). The faster the change, the more sensitive ocean $\mathrm{pH}$ is reacting. According to Hoegh-Guldberg (2005) coral calcification is strongly dependent on the aragonite saturation state, as aragonite is the main crystal form in reef-building corals. With doubling $\mathrm{CO}_{2}$ concentrations ocean acidification due to reduced ocean $\mathrm{pH}$ occurs and the calcification rate of marine organisms is depressed by $10 \%-30 \%$ due to a reduced availability of carbonate ions. Weaker skeletons could be a consequence of this depressed calcification rate, which in turn could lead to an increased susceptibility to mechanical destruction and bioerosion (Kleypas et al., 1999; Andersson et al., 2003). Recent experiments show that such acidification will decrease the ability of corals and other organisms (planktic and benthic) to build their carbonate skeleton (Orr et al., 2005).

\subsection{Variation of magnesium/calcium $(\mathrm{Mg} / \mathrm{Ca})$ ratios}

Investigations of the composition of non-skeletal precipitates like ooids and marine cements indicate that the chemical composition of the seawater has changed during the Phanerozoic (Sandberg, 1983; Stanley, 2006; Fig. 10). The chemical composition, especially the $\mathrm{Mg} / \mathrm{Ca}$ ratio, in turn is responsible for the precipitation of inorganic aragonite or calcite (Berner, 1975) resulting in times during which oceans predominantly precipitated calcite and times of predominant aragonite precipitation (Sandberg, 1983; Stanley, 2006; Fig. 10). During the entire Phanerozoic two periods of "calcite seas" and three periods of "aragonite seas" can be distinguished. During the Cretaceous to early Paleogene a calcite sea with very low $\mathrm{Mg} / \mathrm{Ca}$ ratios prevailed, whereas since the late Paleogene an "aragonite sea" prevailed (Fig. 10). Not only inorganic precipitates are affected by these changes but they may have consequences for skeletal growth of certain organism groups as well (Stanley, 2006). Skeletal secretion of aragonitic scleractinian corals for example is dependent on the $\mathrm{Mg} / \mathrm{Ca}$ ratio in the seawater and therefore scleractinian coral growth is increased during times of aragonite seas (Stanley, 2006). Recent laboratory tests proved that scleractinian coral calcification is affected by ambient seawater chemistry (Ries et al., 2006). The effects of seawater chemistry on coral biomineralization are probably partly responsible for the diminishing importance of corals as reefbuilding organisms in the late Cretaceous, a time of a calcite sea with a low $\mathrm{Mg} / \mathrm{Ca}$ ratio. At the same time rudists, with their calcite skeleton inherited the role of the previously dominant corals (Kauffman and Johnson, 1988). This calcitic dominance in the oceans lasted until the Oligocene, when the ocean chemistry switched back to aragonitic conditions, which continue today. Consequently, from the beginning of the Oligocene onwards scleractinian corals again were the dominant reef-building organisms (Geel, 2000).

\subsection{Early Paleogene coral reef distribution}

In a study on the extinction and recovery patterns of scleractinian corals at the Cretaceous-Tertiary boundary Kiessling and Baron-Szabo (2004) reported a very low coral extinction rate, in comparison to other benthic marine invertebrates. Apparently, corals benefited from the $\mathrm{K} / \mathrm{T}$ extinction event, as they became more abundant in the Paleocene than in the late Cretaceous, in which carbonate platforms were often dominated by rudists. Although coral reefs and corals have been rare throughout the entire early Paleogene this review demonstrates that in the early Paleocene corals were quite common in low-middle latitudes (Vecsei and Moussavian, 1997; Kiessling and Baron-Szabo, 2004; Baceta et al., 2005), while during the latest Paleocene to early Eocene the sea floor was nearly devoid of colonial corals. According to Flügel and Kiessling (2002) and Kiessling and Baron-Szabo (2004), absolute numbers of reefs (i.e. buildups by sessile benthic organisms like corals, sponges and bryozoans) decreased by $25 \%$ from the Thanetian to the Ypresian. The average sizes of the reefs also diminished strongly and global reef carbonate production decreased by $40 \%$ (Flügel and Kiessling, 2002). Parallel to the diminution of reefs the accumulation rates of platform carbonates increased considerably and the carbonate platform area shrank dramatically (Kiessling et al., 2000). The late Paleocene decrease in coral reefs can be observed with latitudinally dependent time lags in all Tethyan areas, where coral patch reefs diminished and were succeeded by larger foraminifera shoals. Additionally encrusting foraminifera (Solenomeris), abundant in the late Paleocene, even started to build reef-like structures in the early Eocene (Plaziat and Perrin, 1992).

Typical framework reefs dominated by coral assemblages, nearly absent in the early Paleogene became the most common type of bioconstruction from the middle Eocene time onwards (Geel, 2000; Perrin, 2002), whereas real barrier reefs appear as early as Oligocene (Geel, 2000). The middle-late Eocene was also the time interval of rapid coral diversification, increasing abundance, geographic distribution, and size of reefs (Fagerstrom, 1987). In the eastern Pacific this time interval is characterized by a first peak in the abundance curve of Cenozoic coral taxa (Budd, 2000; Lopez-Perez, 2005). In the Caribbean the first coral reefs were described from the early Eocene, with the exception of the late Paleocene coral reef in Alabama (Bryan, 1991), and by middle to late Eocene times corals had established diversity, comparable of today's diversity (Budd, 2000).

\section{Parameters controlling larger foraminifera evolution}

Similar to reef-building corals, larger foraminifera are important producers of $\mathrm{CaCO}_{3}$ (Langer, 2008) and are sensitive to changes in water quality. Thus, their distribution and evolution reflects short- and longterm environmental changes in the shallow-water domain (Hallock, 2000). In the following chapter we look in detail into parameters controlling the life and evolution of larger foraminifera, i.e. their sensitivity to solar radiation, to variation of seawater chemistry and to nutrient supply. Furthermore, the concepts of K-strategy and global maturation cycles, both important for the general evolution of larger 
foraminifera, are recapitulated. In the last chapter the larger foraminiferal distribution of the early Paleogene is discussed.

\subsection{Solar radiation sensitivity of larger foraminifera}

Larger foraminifera live within the photic zone where they build tests of several $\mathrm{mm}$ to more than $10 \mathrm{~cm}$ in size. The middle Eocene Nummulites gizehensis, the literal building block of the Great Pyramids in Egypt, ranged even up to $16 \mathrm{~cm}$ (Lee et al., 1979; Purton and Brasier, 1999). Construction of these extremely large tests is only possible through symbiosis with photosynthetic algae. During evolution the tests of larger foraminifera tend to get more complex, larger and test sizes vary to adapt for different bathymetric regimes to evolve to almost perfect "greenhouses" for their symbiont algae (Lee et al., 1979; Hallock, 1988b). Similar to corals, larger foraminifera can also suffer from symbiont loss, causing bleaching and ultimately death. In contrast to reef-building corals, in which the symbionts are sensitive to slight increases in summer sea-surface temperature, symbiont loss or bleaching in larger foraminifera (Amphistegina) shows no correlation to summer temperature (Hallock, 2000, 2005; Hallock et al.,
2006). Bleaching in larger foraminifera is rather related to increased solar radiation, indicating that larger foraminifera are living close to their threshold for this particular stress factor (Hallock, 2005).

\subsection{K-strategy and trophic resource regime}

Larger foraminifera are considered extreme K-strategists (Hottinger, $1983,1998)$ depending on long-term environmental stability. K-strategists are characterized by a long individual life and a low reproductive potential. This life strategy is most advantageous in highly stable, typically oligotrophic environments, where organisms compete by specialization and habitat partitioning (Hallock et al., 1991). Although larger foraminifera as a group are extreme K-strategists, a trend of increasing K-strategy in Paleogene larger foraminifera can be discerned from alveolinids (Glomalveolina, Alveolina) through nummulitids (Ranikothalia, Assilina, Nummulites) and pellatispiridis (Miscellanea) to orthophragminids (Discocyclina) (Hottinger, 1982). During a breakdown or interruption of stable oligotrophic conditions the most extreme K-strategists are the first to disappear (Hottinger, 1983). The PETM represents such an interruption of stable conditions on
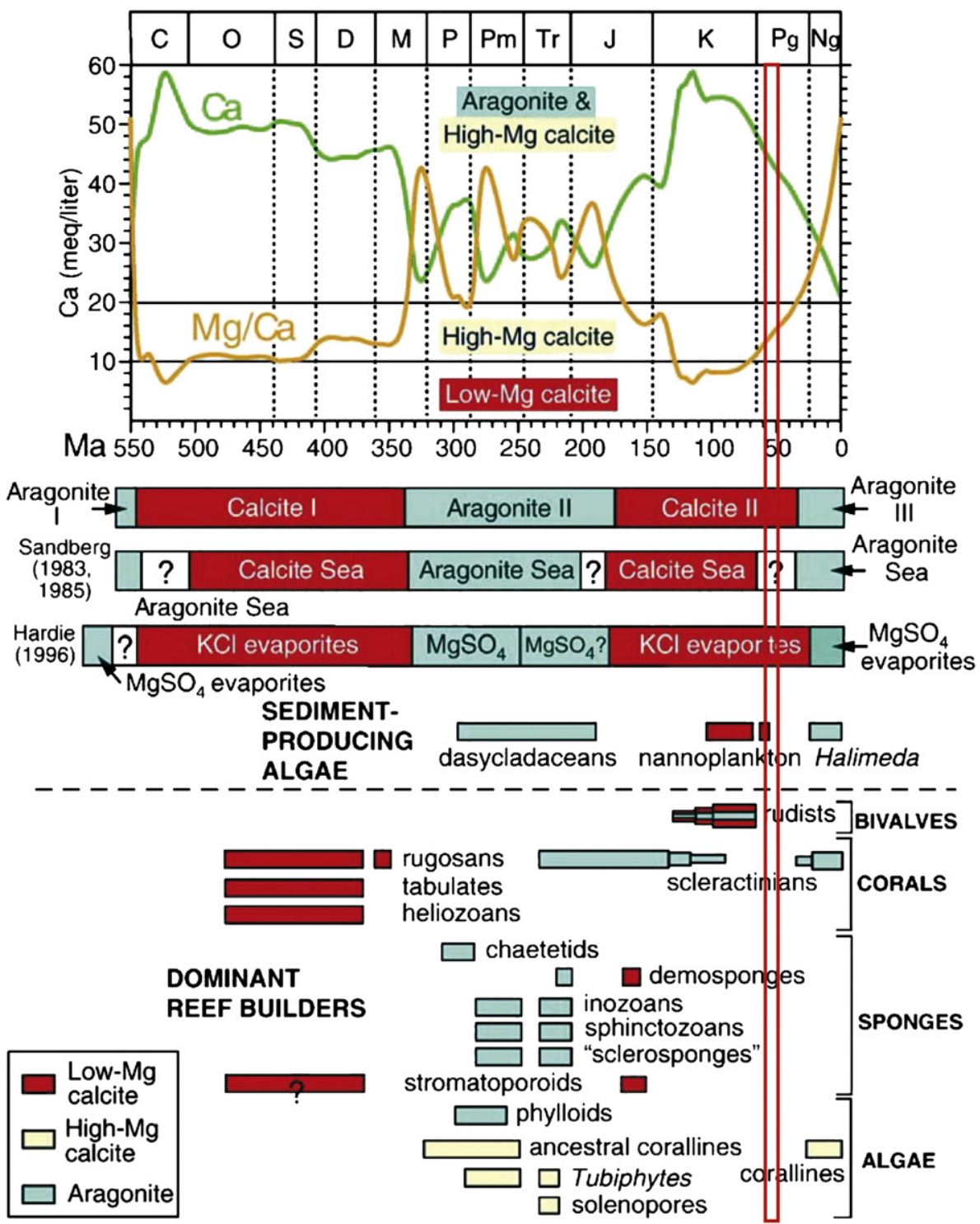

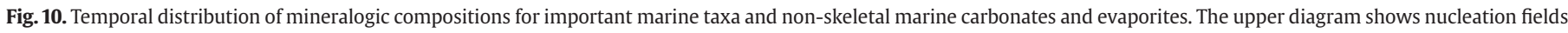

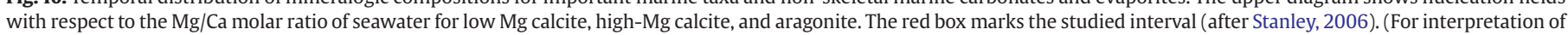
the references to colour in this figure legend, the reader is referred to the web version of this article.) 
continental margins. Prior to the PETM oligotrophic conditions prevailed on many shelf margins providing optimal conditions for larger foraminifera as alveolinids (Glomalveolina), nummulitids (Ranikothalia) or pellatispiridis (Miscellanea). With the onset of the PETM, transient expansion of the trophic resource continuum led to eutrophic conditions on Tethyan continental margins (Speijer et al., 1997). As a result typical extreme K-strategists among larger foraminifera (e.g. Miscellanea, Ranikothalia) disappeared, while more moderate K-strategists like glomalveolinids thrived unaffectedly (Scheibner et al., 2005). A switch from K-strategists to excursion taxa and r-strategists is also observed in smaller benthic foraminifera of deeper waters (Speijer et al., 1997; Thomas, 1998; Speijer and Wagner, 2002) as well as in calcareous nannofossils from the Demerara Rise (South America), an outer continental margin drilling site (Jiang and Wise, 2006). After the return to oligotrophic conditions in the basins and on the platforms the larger foraminifera flourished again with the radiation of Alveolina and Nummulites (Scheibner et al., 2005).

\subsection{Global community maturation cycle (GCM cycle)}

According to Hottinger (1997, 2001, 2006), the long-term evolution of larger foraminifera is controlled by gradual changes in the composition of an assemblage in between two breaks or discontinuities, such as mass extinctions or major environmental changes. During times of ecological disruption, the end members of the K-r strategy gradient suffer the most and are replaced after a certain time by new ones (Hottinger, 2001). This cycle of gradual change between two breaks is called a global community maturation (GCM) cycle (Hottinger, 2001). In the case of Paleogene K-strategist foraminifera the GCM cycle consists of five phases (Hottinger, 2001). The first phase (Danian to Selandian) started with only few surviving larger foraminifera after elimination of nearly all lineages (e.g. Cretaceous Orbitolinidae, Meandropsinidae and Alveolinidae) at the Cretaceous/Paleogene boundary. The first two biozones (SBZ1 and SBZ2; Fig. 1) are characterized by an increase in genera, which have small tests and show virtually no dimorphism. In phase 2 (Selandian to Thanetian; SBZ3 and SBZ4; Fig. 1), larger foraminifera start with the experimentation of new morphologies, and a further increase in generic diversity, while in phase 3 (early Ilerdian; SBZ5 and SBZ6; Fig. 1) a general reconstitution of larger foraminifera occurred with a diversification of the species belonging to successful genera (Hottinger 1997, 2001). This phase in the GCM cycle marks the full recovery of K-strategy in larger foraminifera and lasted as long as the environmental conditions remained stable (Hottinger, 2001). After recovery in phase 3, phase 4 (late Ilerdian to Lutetian; SBZ7 to SBZ14/15) is characterized by a size increase and a further diversification of the successful lineages. This cycle ended about 23 m.y. later in the late middle Eocene (late Lutetian to early Bartonian, SBZ15 and SBZ 16) with phase 5 , characterized by a decrease in species diversity.

The experimentation of new life strategies of larger foraminifera in phase 2 of the GCM cycle (SBZ3 and SBZ4, Plate 1) correlates with the Tethyan platform stages I and II, in which larger foraminifera gradually took over former live habitats of corals. The onset of phase 3 of the GCM cycle (SBZ5 and SBZ6, Plate 1), which marks the full recovery of K-strategy and an increase in species diversification, coincides with the PETM and the Larger Foraminifera Turnover of Orue-Etxebarria et al. (2001) and marks also the beginning of carbonate platform stage III. Apparently the PETM marks no or just a minor break in the overall Paleogene larger foraminifera GCM cycle, with the disappearance of only the most extreme K-strategists among the larger foraminifera (see Section 6.2). As the PETM coincides with the onset of phase 3 (full success of larger foraminifera) of the GCM cycle, the PETM may serve as a trigger for this phase.

\subsection{Early Paleogene larger foraminifera distribution}

Paleogene and Neogene larger foraminifera can be assigned into three bioprovinces worldwide: Mediterranean, Indo-West Pacific, and
Central American (Adams, 1983). A more recent paleobiogeographic study subdivided the Mediterranean and Indo-West Pacific Paleogene larger foraminifera into three major provinces: Europe and the Mediterranean; NE Africa and the Near/Middle East, which included in some time intervals the Apulian plate and India; SE Asia and the W Pacific (Pignatti, 1994). The shallow benthic zonation of Serra-Kiel et al. (1998) can be relied on in the first two provinces of Pignatti (1994). The reason for such biogeoprovincialism remains unclear, as within different times slices cosmopolitan genera are existent. Langer and Hottinger (2000) studied the recent biogeography of selected larger foraminifera and mentioned two reasons for biogeography, temperature, which is responsible for latitudinal separation and a steep trophic gradient, which could be responsible for longitudinal separation. In the Paleocene, Ranikothalia bermudezi and Discocyclina for example occur within all biogeoprovinces, while Alveolina primaeva is restricted to the Tethyan realm as far as E India (Adams, 1973; Hottinger, 1973; Fleury et al., 1985). A possible explanation for cosmopolitan genera might be the fact that their occurrence coincides with times of recolonization of former vacant niches as in the Paleocene or Oligocene (Adams, 1973). Both times can be roughly related to the recovery phase at the beginning of the GCM cycle of Hottinger (2001), where the competition among larger foraminifera just started and therefore was not as severe as in later phases. A summary of the generic distribution of nummulitids has been done by Racey (1994). Ranikothalia is present in the Paleocene in all three provinces of Adams (1973), while in the Eocene it is restricted to Central America. Assilina and Nummulites are present from the late Paleocene to the late middle Eocene/Oligocene in the Indopacific and Mediterranean, while absent or very rare in Central America, respectively.

The rapid diversification of larger foraminifera in the early Paleogene is probably caused by a combination of the reconstitution of the K-strategist larger foraminifera, rising sea-surface temperatures, leading to the decline of coral reefs, and the overall oligotrophic conditions during this time interval (Scheibner et al., 2005). The faunal changes in the Paleocene to Eocene, upon which the shallow benthic zonation of Serra-Kiel et al. (1998) is based, are thought to relate to eustatic sea-level changes (Adams, 1983; Seiglie, 1987; Pignatti, 1991). Most of the larger foraminifera-rich deposits and thus most of the newly evolved species should have been formed in the transgressive to early highstand systems tracts (Seiglie, 1987; Pignatti, 1991), i.e. during times of expansion of hospitable shelf areas. Comparable to the change in latitudinal distribution of corals through the early Paleogene, there probably also exists a longitudinal and/or latitudinal change within the distribution of the different larger foraminifera genera/species, as in some regions larger foraminifera, typical for SBZ4 (Miscellanea, Ranikothalia) are still present in SBZ5/6. In a comparison of larger foraminiferal distribution patterns of the Mediterranean and the Far East, Hottinger (1971) pointed out that larger foraminifera assemblages are similar but not identical in both areas. Furthermore, the zonal scheme of the Paleogene larger foraminifera biostratigraphy of the Far East is much more incomplete than that of the Mediterranean Paleogene. These different distribution patterns might also reflect the fact, that certain areas are investigated in greater detail than others (Leppig, 1988). One example for this inhomogeneous research pattern is the distribution of Miscellanea. In a revision of Miscellanea, Leppig (1988) pointed out that the early forms of Miscellanea are only reported from the western Tethys, while the later forms ( $M$. miscella) are restricted to the eastern Tethys. However, later studies reported the early forms of Miscellanea also in the eastern Tethys (NE India) as well (Jauhri, 1998). The most eastern Tethyan area in this study (NE India) is also considered to be exceptional in its early Eocene foraminiferal content, as the typical Alveolina s.s. and Nummulites are not present and instead the Paleocene taxa of Miscellanea and Ranikothalia are still thriving in this area up to SBZ6 (Jauhri, 1996). Only from that time onwards Alveolina 

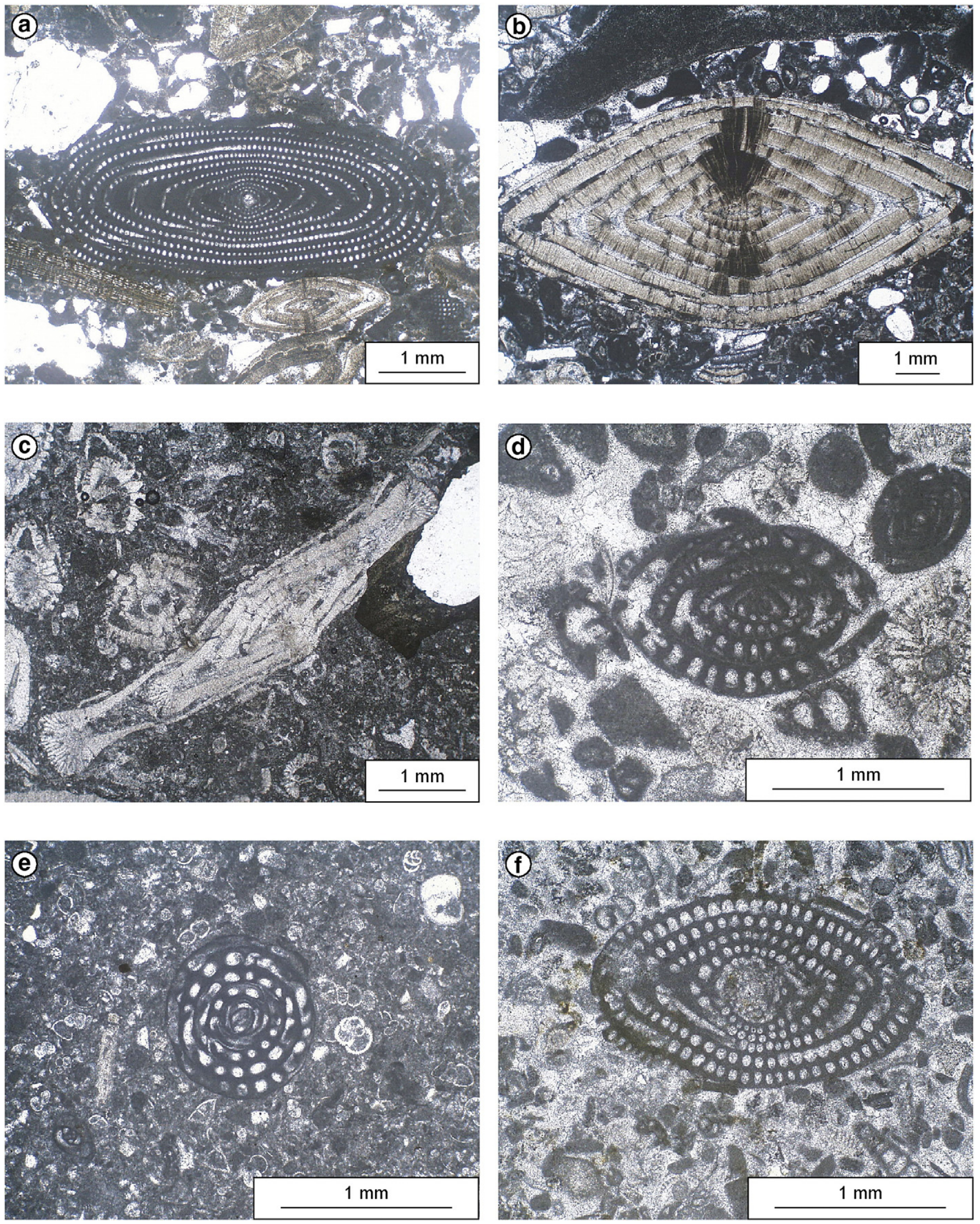

Plate 1. Characteristic larger foraminifera of the different platform stages: A) Alveolina vredenburgi; SBZ5; platform stage III; magnification 20×. B) Nummulites sp.; SBZ8; platform stage III; magnification 20x. C) Ranikothalia nuttalli, middle; Miscellanea cf. rhomboidea top left; SBZ4; platform stage III; magnification 20×. D) Hottingerina lukasi; SBZ4; platform stage II; magnification 40×. E) Glomalveolina primaeva; SBZ3; platform stage I; magnification 40×. F) Glomalveolina levis; SBZ4; platform stage II; magnification 40×. 
and Nummulites became the dominant genera, while Miscellanea and Ranikothalia disappear or become unimportant. The reason for this exceptional faunal composition might be the rise of fewer larger foraminiferal groups than in the western Tethys, leading to less competition for the same habitat and enhanced survival of older lineages (Leppig, 1988). The exceptional faunal composition in NE India might be also explained by different responses of the larger foraminifera in the western and eastern Tethyan provinces to the PETM. Perhaps the PETM did not perturb platform environments on the Indian subcontinent as intensely as in the western Tethys. Detailed PETM data from this region are required to test this speculation.

At the end of the Eocene several larger "Paleogene" foraminiferal lineages became extinct and in turn were succeeded by newly evolving "Neogene" larger foraminifera in the Oligocene (Adams, 1973), although stratigraphically the Oligocene is still attributed to the Paleogene.

\section{Causes for the platform evolution in the early Paleogene}

In the previous chapters we collected evidence for a threefold carbonate platform development in the Tethyan realm during the early Paleogene based on 17 areas from the northern to the southern margin of the Tethys. Subsequently we discussed climate proxies for the early Paleogene in general, focusing on temperature, $\mathrm{CO}_{2}$ and precipitation changes. After this general discussion we reviewed the parameters controlling the distribution of corals and larger foraminifera, two of the important carbonate platform dwelling organism groups.

In the following two chapters we evaluate the geologic data of the Tethyan carbonate platforms in the light of the early Paleogene climate and organism evolution to explain the succession of the three platform stages. As the different time scales involved are a key issue to explain the causes for the different platform stages, we separate consequences of long-term causes from those of short-term causes, although one parameter, e.g. temperature can be effective at both time scales. The long-term causes set the basis for the overall platform evolution trend and are responsible for the transition from platform stage I to platform stage II, but continued into platform stage III. The short-term causes on the other hand are related to the impact of the PETM hyperthermal and thus are responsible for the transition from platform stage II to platform stage III. Further Eocene hyperthermals, similar but with minor magnitudes to the PETM, and their possible effects on early Paleogene carbonate platform evolutions are listed in Section 7.3.

\subsection{Long-term causes}

The main factors controlling the long-term evolution of early Paleogene Tethyan carbonate platforms are expansion and reduction of the trophic resource continuum, $\mathrm{CO}_{2}$ and temperature changes. The first platform stage starts at the beginning of the long-term warming at the base of the Thanetian. This long-term warming trend culminated at the Early Eocene Climatic Optimum. Widespread oligotrophic conditions could have favored the migration and settlement of corals, but they did not. The overall marginal appearance of coral reefs during the early Paleogene might be explained by the predominance of a calcite sea with low $\mathrm{Mg} / \mathrm{Ca}$ values, hampering aragonitic corals to construct their skeleton, while larger foraminifera appear not to be affected by changing $\mathrm{Mg} / \mathrm{Ca}$ values. However, the presence of a calcite sea during late Cretaceous to early Paleogene might only explain the overall scarcity of corals in this time interval, but not the decreasing trend documented in this study. Overall this study highlights the fact that coral reefs are still important contributors for carbonate platforms during the Paleocene. The only exception to this general pattern in our study is the Moroccan platform, where cold nutrient rich upwelling waters favored the construction of oyster banks over organisms like corals or larger foraminifera preferring warmer oligotrophic waters (Herbig, 1986). Conditions on the Moroccan platform remained similar for the entire studied interval (stages I-III).

During platform stage II, global warming continued and coral reefs shifted from the low latitudes to the middle latitudes, while larger foraminifera took over this niche in the low latitudes and started to diversify. We relate this latitudinal shift to increases in SST. The question remains open why coral reefs might be affected by a gradual increase in SST. Normally coral reefs are capable to adapt to such an increase, but in cases of an already high SST, as in the late Paleocene, which is close to the upper absolute thermal threshold for corals, even slight temperature increases or repeated temperature anomalies may cause a withdrawal of the coral reefs to more favorable areas. If the recent model of Sewall et al. (2004; Fig. 8) represents a realistic scenario for SST distribution patterns for the early Paleogene, then the highest temperatures occurred in the eastern Tethys around the Indian subcontinent and on the eastern side of Africa, up to NE Africa, while the western Tethys would be bathed in "cooler" waters (Fig. 8). It is indeed in the warmer eastern Tethys where we find the transition from coralgal reefs to larger foraminifera shoals during platform stage II, while coralgal reefs remained important carbonate platform constructions in the rest of the western Tethys (Fig. 8). A similar transitional shift of carbonate platforms is documented by Wilson et al. (1998) and Jenkyns and Wilson (1999) in a study on the evolution of different Cretaceous guyots, located in the Pacific. They concluded that these carbonate platforms were drowned during the passage across the equator and inferred high paleotemperatures as the most reasonable cause for decline and subsequent drowning. During the passage across the equator region the previous shallow-water platforms were exposed to gradually increasing temperatures, which hampered the platform growth and subsequently these platforms subsided to greater water depth, at which a recovery of the platform organisms was impossible. A negative effect of higher temperatures on the position of coral reefs is also reported from the Mediterranean Miocene (Pomar and Hallock, 2007), where coral growth occurred at higher latitudes and in deeper waters in comparison with today. These shifts were partly attributed to the somewhat higher temperatures. With decreasing temperatures in the late Miocene the coral habitats migrated upwards to shallower depths (Pomar and Hallock, 2007).

Platform stage II was also the time in which larger foraminifera experienced new morphologies and increased in generic diversity after the crisis of the Cretaceous/Paleogene boundary. By the onset of platform stage III larger foraminifera had completely recovered from the near extinction at the Cretaceous/Paleogene boundary. The combination of very warm and stressful conditions for corals and the full recovery of larger foraminifera led to a replacement of coralgal reefs by larger foraminifera. As temperature rise was more effective in the low latitudes, replacement by larger foraminifera started in the low latitudes, while in the middle latitudes temperatures were still favorable for coralgal reefs. This shift in organism distribution from coralgal reefs to larger foraminifera is most accentuated at this interval (phase 3 ) of the Paleogene larger foraminifera GCM cycle. Had the PETM occurred during phase 1 or 2 of the GCM cycle, larger foraminifera probably may not have been evolutionarily well equipped for such dominance and other organisms, as the rudists in the late Cretaceous, could have dominated shallow-water platforms. On the other hand, if the PETM occurred later during the GCM cycle, the successful larger foraminifera genera would have been already established and may have not had the potential to diversify any further and would have reacted only with minor modifications and replacements. This hypothesis might be tested at the younger hyperthermals (see Section 7.3).

\subsection{Short-term causes}

The onset of platform stage III coincided with the PETM, which resulted in an extreme short-term temperature rise, short-term 
eutrophic conditions on the shelf areas and rapid acidification of the deeper ocean due to oxidation of methane to $\mathrm{CO}_{2}$ (Hallock et al., 1991; Zachos et al., 2003, 2005). During the PETM SST rose about $5{ }^{\circ} \mathrm{C}$ in low latitudes and up to $8^{\circ} \mathrm{C}$ in middle to high latitudes (Zachos et al., 2003, 2006; Tripati and Elderfield, 2004). This temperature rise was probably beyond the range of adaptation capacity for coral reefs. The climate changes, associated with the PETM, towards more humidity and subsequent increased runoff in the Tethyan realm (Bolle and Adatte, 2001) and/or intensified upwelling (Speijer and Wagner, 2002) led to a short-term eutrophication in the coastal areas, which further hampered coral reef growth and resulted in a change from larger foraminifera association I (miscellaneids, Ranikothalia) to larger foraminifera association II, dominated by alveolinids and nummulitids, the so-called Larger Foraminiferal Turnover of Orue-Extebarria et al. (2001). This Larger Foraminiferal Turnover is characterized by a high diversification, indicating phase 3 in the global community maturation (GCM) cycle of Paleogene larger foraminifera. The coincidence of the PETM and the Larger Foraminiferal Turnover or phase 3 of the GCM cycle suggests a connection between both. It's probable that the PETM triggered this step in larger foraminiferal evolution. During the PETM, oxidation of the methane released from the sea floor produced $\mathrm{CO}_{2}$, causing dissolution of deep-sea carbonate and raising the calciumcarbonate depth (CCD) by at least $2 \mathrm{~km}$ leading to an acidification of the oceans (Zachos et al., 2005), which also could have effected the $\mathrm{pH}$ of surface waters. This could have hampered the calcification rate of corals and thus contributed to the overall decline of coral reefs. All these factors affected coralgal reefs and corals negatively and resulted in the decline of corals at the beginning of the Eocene. Larger foraminifera were also affected from eutrophication and $\mathrm{CO}_{2}$ rise, but especially the temperature increase seems to have been a much less important controlling parameter.

A further short-term effect, which is not only restricted to the PETM time interval but could be effective probably during the overall warm early Paleogene are variations in the proto-ENSO activity. A modeled ENSO activity for the Eocene (Huber and Caballero, 2003), with a higher magnitude and thus higher temperatures extremes than today could have hampered the ability of corals to recover from previous warming events, if these occur in a series, thus leading to an overall retreat of coral reefs.

The regeneration of coral reefs started with small reefs only in the middle Eocene, a time when $\mathrm{CO}_{2}$ concentrations dropped to 2-3 times pre-industrial concentrations and only when in the Oligocene these concentrations had declined further and seawater chemistry switched from a calcite sea to an aragonite sea, widespread coral reef buildups were created (Geel, 2000; Hallock, 2005).

\subsection{Early Paleogene hyperthermal events}

In this paper we concentrate on a short time interval (5 my) across the Paleocene/Eocene boundary (-60 Ma-55 Ma). The prominent event during this interval was the PETM hyperthermal at which substantial changes happened (transition from platform stage II to platform stage III). Recent investigations from ODP and IODP drilling sites on the Shatsky Rise (Western Pacific Ocean; Bralower et al., 2002), Demerara Rise (Northern Atlantic; Sexton et al., 2006b) and Walvis Ridge (Southern Atlantic; Kroon et al., 2007) revealed the occurrence of further possible hyperthermals in the deep ocean (Kroon et al., 2007). These deep marine hyperthermal findings were supported by similar CIE's in shallow-marine sediments from the continental margin of New Zealand (Nicolo et al., 2007). Evidence for a first transient climatic warming was found in the early late Paleocene at ca. 58.4 Ma (Bralower et al., 2002; Kroon et al., 2007).

In the early Eocene two additional hyperthermal events are discussed, although they are smaller in magnitude in comparison with the PETM (CIE of 2.5\%o). The carbon isotopic excursion of the Elmo horizon measures roughly $1.5 \%$ - $2 \%$, while the carbon isotopic excursion for the X-event lies between $0.6 \%$ and $1.0 \%$. The Elmo horizon at $53.5 \mathrm{Ma}$ is linked with a rise in sea-surface temperature of about $3^{\circ}-4{ }^{\circ} \mathrm{C}$ (Lourens et al., 2005; Dutton et al., 2005) and a rise in deep-sea temperature of $2^{\circ}-3^{\circ}$ (Kroon et al., 2007). As the investigations on the X-event (52 Ma) are still ongoing (Röhl et al., 2005), no further results can be presented so far. The timing of the X-event correlates roughly with the onset of the Early Eocene Climatic Optimum (52-50 Ma; Zachos et al., 2001).

Whether these apparently global events have had additional effects on shallow-water platforms, similar to those of the PETM remains for the moment uncertain and needs further research. However, a comparison of the timing of these events with the larger foraminifera diversity curves of Hottinger (1998; Fig. 1) makes a connection at least possible, as larger foraminifera diversity peaks similar to the diversity peak at the PETM occur at these hyperthermals.

\section{Consequences for future reef systems}

If global SST continues to rise further, it is logical to assume that areas favorable for reef growth at higher latitudes would become available. This poleward expansion of reefs has occurred previously (Kleypas et al., 2001) and has also been demonstrated for the Eocene (Adams et al., 1990), where reef-building corals were found at paleolatitudes up to $51^{\circ} \mathrm{N}$ (Wallace and Rosen, 2006). But estimates for today suggest that effects of geographic expansion are very minor in comparison to the overall negative effects (Buddemeier et al., 2004).

Recently the idea of an "ocean thermostat" that preserves SSTs in the ocean around $30^{\circ}-31^{\circ} \mathrm{C}$ has been adopted to predict the possibility of less coral bleaching in the near future (Kleypas et al., 2008). But given the results of this study and the most recent SST reconstructions for the Paleocene-Eocene it is doubtful, whether the threshold of such an "ocean thermostat" is limited to $30^{\circ}-31^{\circ} \mathrm{C}$. At least during the Paleocene/Eocene the thermostat had a higher threshold.

A thorough review on climate change, coral bleaching, human impact and the future of the world's coral reefs is given in HoeghGuldberg (1999), Wilkinson (1999) and Hoegh-Guldberg et al. (2007). They conclude that coral reefs are under threat in the decades to follow, but on a long-term prognosis (centuries to millennia) coral reefs probably have a good resilience if climate changes stabilize or reverse (Wilkinson, 1999; Hoegh-Guldberg, 1999). Furthermore, climate changes are not the only negative factors controlling reef growth. According to Pandolfi et al. (2003) coral reefs have suffered in the past extensively from human pollution (excess nutrient input) and overfishing (reduction of herbivory), which were mainly responsible for the reef degradation in historical times. Only recently these factors were superseded by coral disease and bleaching (Pandolfi et al., 2003). But if the rate of climate change (i.e. temperature increase) in combination with overfishing and coral diseases, which are still important parameters in coral reef reduction, outpace or hamper the capacity of coral reefs to adapt to such a warming (Hughes et al., 2003), the PETM might be a possible scenario for tropical reef sites. Hallock (2005) pointed out that "If the Eocene is a useful model, calcite foraminifers and coralline algae may once again predominate shallow-water carbonates, as aragonitic corals and calcareous green algae become less common". Even in this worst-case scenario coral reefs would probably not go extinct, at least not on the geological time scale, as this study reveals, but reductions of coral diversity might be severe nevertheless.

\section{Conclusions}

Rising temperatures during the latest Paleocene to early Eocene and the short-term effects during the PETM (temperature rise, eutrophication, $\mathrm{CO}_{2}$ input) led to the decline of reef-building corals in the Tethys. In the absence of other reef-building organisms that tolerate higher temperatures, as rudists in the late Cretaceous, larger foraminifera could take over the role as a carbonate producer in 
platform environments. The late Paleocene to earliest Eocene is an important period within the global maturation cycle of early Paleogene larger foraminifera. Within the time interval studied, phases 2 and 3 of this cycle, experimentation with new morphologies and full recovery, respectively, developed. The interaction of the physical effects on corals and the evolution of larger foraminifera resulted in three Tethyswide platform stages. In platform stage I coral reefs were common at all latitudes, while larger foraminifera just started to recover from their decline at the Cretaceous/Paleogene boundary. The second platform stage is characterized by a latitudinal gradient in the coral reef distribution. Coral reefs were more or less absent at low latitudes, while at middle latitudes coral reefs were still present. The latitudinal pattern in coral reef distribution probably results at least partly from the latitudinal temperature gradient, with high temperatures in the southern Tethys, especially around India. This is supported by the latest climate modeling studies. An open question remains the reliability of these models, as they still have problems to simulate simultaneous warm low and high latitudes. The coral reefs in the low latitudes were superseded in platform stage II by a suite of larger foraminifera (including Miscellanea and Ranikothalia). In the western Tethys these foraminifera are indicative for the second platform stage, while in the eastern Tethys (India) they are present in platform stage III as well. The beginning of the third platform stage is closely related to the effects of the PETM. It is characterized by a strong increase in sea-surface temperatures and a general increase in $\mathrm{CO}_{2}$ in the atmosphere and the ocean. The trophic resource continuum expanded during the PETM, with short-term regional changes from oligotrophic to eutrophic conditions in shelf areas and oligotrophic conditions in the open ocean. These events at the PETM led to the decline of the coral reefs and of the most extreme K-strategist within the larger foraminifera that previously flourished on the carbonate platforms. After the return to stable oligotrophic conditions, nummulitids and alveolinids occupied the vacated niches, as the PETM marks the onset of the full recovery and diversification of larger foraminifera. This diversification leads to the Larger Foraminiferal Turnover and larger foraminifera thrived till the middle Eocene, a time when coral reefs became more abundant again. If the destruction of today's coral reef sites continues, the PETM might be a possible scenario for these environments.

\section{Acknowledgements}

J.R. Reijmer is thanked for critical reading of a previous version of this manuscript. We thank J. Pignatti and an unknown reviewer for valuable comments, which improved the paper.

\section{References}

Accordi, G., Carbone, F., Pignatti, J.S., 1998. Depositional history of a Paleogene carbonate ramp (Western Cephalonia, Ionian Islands, Greece). Geologica Romana 34, 131-205.

Adams, C.G., 1973. Some Tertiary foraminifera. In: Hallam, A. (Ed.), Atlas of Palaeobiogeography. Elsevier, Amsterdam, pp. 453-468.

Adams, C.G., 1983. Speciation, phylogenesis, tectonism, climate and eustasy: factors in the evolution of Cenozoic larger foraminiferal bioprovinces. In: Sims, R.W., Price, J.H., Whalley, P.E.S. (Eds.), Evolution, time and space: the emergence of the biosphere. Academic Press, London, pp. 255-289.

Adams, C.G., Lee, D.E., Rosen, B.R., 1990. Conflicting isotopic and biotic evidence for tropical sea-surface temperatures during the Tertiary. Palaeogeography, Palaeoclimatology, Palaeoecology 77, 289-313.

Agnini, C., Fornaciari, E., Raffi, I., Rio, D., Röhl, U., Westerhold, T., 2007. High-resolution nannofossil biochronology of middle Paleocene to early Eocene at ODP Site 1262: Implications for calcareous nannoplankton evolution. Marine Micropaleontology 64 $215-248$.

Aguirre, J., Baceta, J.I., Braga, J.C., 2007. Recovery of marine primary producers after the Cretaceous-Tertiary mass extinction: Paleocene calcareous red algae from the Iberian Peninsula. Palaegeography, Palaeoclimatology, Palaeoecology 249, 393-411.

Andersson, A.J., Mackenzie, F.T., May Ver, L., 2003. Solution of shallow-water carbonates: an insignificant buffer against rising atmospheric $\mathrm{CO}_{2}$. Geology 31, 513-516.

Ahlbrandt, T.S., 2001. The Sirte Basin Province of Libya-Sirte-Zelten total petroleum system. US Geological Survey Bulletin 2202-F http://geology.cr.usgs.gov/pub bulletins/b2202-f pp.
Aubry, M.P., 1995. Towards an upper Paleocene-lower Eocene high resolution stratigraphy based on calcareous nannofossil stratigraphy. Israel Journal of Earth Sciences 44, 239-253.

Aubry, M.P., Ouda, K., 2003. Introduction to the upper Paleocene-Lower Eocene of the Upper Nile Valley: Part I Stratigraphy. Micropaleontology 49 (supplement 1), ii-iv.

Babic, L., Zupanic, J., 1981. Various pore types in a Paleocene reef, Banja, Yugoslavia. In: Toomey, D.F.(Ed.), European Fossil Reef Models. . SEPM Spec. Publ., vol. 30. SEPM, Tulsa, pp. 473-482.

Baceta, J.I., Pujalte, V., Bernaola, G., 2005. Paleocene coralgal reefs of the western Pyrenean basin, northern Spain: new evidence supporting an earliest Paleogene recovery of reefal systems. Palaegeography, Palaeoclimatology, Palaeoecology 224, 117-143.

Bains, S., Corfield, R.M., Norris, R.D., 1999. Mechanisms of climate warming at the end of the Paleocene. Science 285, 724-727.

Bains, S., Norris, R.D., Corfield, R.M., Faul, K.L., 2000. Termination of global warmth at the Palaeocene/Eocene boundary through productivity feedback. Nature 407, 171-174.

Barthel, K.W., Herrmann-Degen, W., 1981. Late Cretaceous and Early Tertiary stratigraphy in the Great Sand Sea and its margins (Farafra and Dakhla Oasis), SW Desert, Egypt. Mitteilungen der Bayerischen Staatssammlung für Paläontologie und historische Geologie 21, 141-182.

Barton, A.D., Casey, K.S., 2005. Climatological context for large-scale coral bleaching. Coral Reefs 24, 536-554.

Bebout, D.G., Pendexter, C., 1975. Secondary carbonate porosity as related to early Tertiary depositional facies, Zelten Field, Libya. AAPG Bulletin 59, 665-693.

Beck, R.A., Sinha, A., Burbank, D.W., Sercombe, W.J., Khan, A.M., 1998. Climatic, oceanographic, and isotopic consequences of the Paleocene India-Asia collision. In: Aubry, M.P., Lucas, S.G., Berggren, W.A. (Eds.), Late Paleocene-Early Eocene Climatic and Biotic Events in the Marine and Terrestrial Records. Columbia University Press, New York, pp. 103-117.

Berggren, W.A., 2007. Status of the hierarchical subdivision of higher order marine Cenozoic chronostratigraphic units. Stratigraphy 4, 99-108.

Berggren, W.A., Pearson, P.N., 2005. A revised tropical to subtropical Paleogene planktonic foraminiferal zonation. Journal of Foraminiferal Research 35, 279-298.

Berggren, W.A., Kent, D.V., Swisher III, C.C., Aubry, M.P., 1995. A revised Cenozoic geochronology and chronostratigraphy. In: Berggren, W.A., Kent, D.V., Aubry, M.P., Hardenbol, J. (Eds.), Geochronology, Time Scales, and Global Stratigraphic Correlation. . SEPM Spec. Publ., vol. 54. SEPM, Tulsa, pp. 129-212.

Berner, R.A., 1975. The role of magnesium in crystal growth of calcite and aragonite from seawater. Science 170, 1305-1308.

Berner, R.A., Kothavala, Z., 2001. Geocarb III: a rivised model of athmospheric $\mathrm{CO}_{2}$ over Phanerozoic time. American Journal of Science 301, 182-204.

Bice, K.L., Marotzke, J., 2001. Numerical evidence against reversed thermohaline circulation in the warm Paleocene/Eocene ocean. Journal of Geophysical Research 106, 11529-11542.

Bice, K.L., Barron, E.J., Peterson, W.H., 1997. Continental runoff and early Cenozoic bottom-water sources. Geology 25, 951-954.

Bice, K.L., Sloan, L.C., Barron, E.J., 2000. Comparison of early Eocene isotopic paleotemperatures and the three-dimensional OGCM temperature field: the potential for use of model-derived surface water $d^{18} \mathrm{O}$. In: Huber, B.T., MacLeod, K.G., Wing, S.L. (Eds.), Warm Climates in Earth History. Cambridge University Press, Cambridge, pp. 79-131.

Bice, K.L., Birgel, D., Meyers, P.A., Dahl, K.A., Hinrichs, K.U., Norris, R.D., 2006. A multiple proxy and model study of Cretaceous upper ocean temperature and atmospheric $\mathrm{CO}_{2}$ concentrations. Paleoceanography 21. doi:10.1029/2005PA001203.

Boersma, A., Premoli Silva, I., Hallock, P., 1998. Trophic models for the well-mixed and poorly mixed warm oceans across the Paleocene/Eocene epoch boundary. In: Aubry, M.P., Lucas, S.G., Berggren, W.A. (Eds.), Late Paleocene-Early Eocene Climatic and Biotic Events in the Marine and Terrestrial Records. Columbia University Press, New York, pp. 204-213.

Bolle, M.P., Adatte, T., 2001. Palaeocene-early Eocene climatic evolution in the Tethyan realm: clay mineral evidence. Clay Minerals 36, 249-261.

Bolle, M.P., Adatte, T., Keller, G., von Salis, K., Hunziker, J., 1998. Biostratigraphy, mineralogy and geochemistry of the Trabakua Pass and Ermua sections in Spain: Paleocene-Eocene transition. Eclogae Geologicae Helvetiae 91, 1-25.

Bolle, M.P., Adatte, T., Keller, G., von Salis, K., Burns, S., 1999. The Paleocene-Eocene transition in the southern Tethys (Tunesia): climatic and environmental fluctuations. Bulletin de la Societé géologique de France 170, 661-680.

Bolle, M.P., Pardo, A., Adatte, T., von Salis, K., Burns, S., 2000a. Climatic evolution on the southeastern margin of the Tethys (Negev, Israel) from the Palaeocene to the early Eocene: focus on the late Palaeocene Thermal Maximum. Journal of the Geological Society, London 157, 929-941.

Bolle, M.P., Pardo, A., Hinrichs, K.U., Adatte, T., von Salis, K., Burns, S., Keller, G., Muzylev, N., 2000b. The Paleocene-Eocene transition in the marginal northeastern Tethys (Kazakhstan and Uzbekistan). International Journal of Earth Sciences 89, 390-414.

Bolle, M.P., Tantawy, A.A., Pardo, A., Adatte, T., Burns, S., Kassab, A., 2000c. Climatic and environmental changes documented in the upper Paleocene to lower Eocene of Egypt. Eclogae Geologicae Helvetiae 93, 33-51.

Bowen, G.J., Beerling, D.J., Koch, P.L., Zachos, J.C., Quattlebaum, T., 2004. A humid climate state during the Palaeocene/Eocene Thermal Maximum. Nature 452, 495-499.

Brady, T.J., Campbell, N.D.J., Maher, C.E., 1980. Intisar “D” Oil Field, Libya. In: Halbouty, M.T.(Ed.), Giant Oil and Gas Fields of the Decade 1968-1978. . AAPG Mem., vol. 30. AAPG, Tulsa, pp. 543-564

Bralower, T.J., 2002. Evidence of surface water oligotrophy during the PaleoceneEocene Thermal Maximum: nannofossil assemblage data from the Ocean Drilling Program Site 690, Maud Rise, Weddell Sea. Paleoceanography 17 10.1029/ 2001PA000662. 
Bralower, T.J., Premoli Silva, I., Malone, M.J., 2002. New evidence for abrupt climate change in the Cretaceous and Paleogene: an Ocean Drilling Program expedition to Shatsky Rise, northwest Pacific. GSA Today 12, 4-10.

Brown, B.E., 1997. Coral bleaching: causes and consequences. Coral Reefs 16, S129-S138 Suppl.

Bryan, J.R., 1991. A Paleocene coral-algal-sponge reef from southwestern Alabama and the ecology of Early Tertiary reefs. Lethaia 24, 423-438.

Budd, A.F., 2000. Diversity and extinction in the Cenozoic history of Caribbean reefs. Coral Reefs 19, 25-35.

Buddemeier, R.W., Kleypas, J.A., Aronson, R.B., 2004. Coral reefs \& global climate change: potential contributions of climate change to stresses on coral reef ecosystems. Pew Center on Global Climate Change,1-44. http://www.pewclimate.org/global-warmingin-depth/all_reports/coral_reefs/index.cfm.

Caldeira, K., Wickett, M.E., 2003. Anthropogenic carbon and ocean pH. Nature 425, 365.

Carbone, F., Matteucci, R., Pignatti, J.S., Russo, A., 1993. Facies analysis and biostratigraphy of the Auradu Limestone Formation in the Berbera-Sheikh Area, northwestern Somalia. Geologica Romana 29, 213-235.

Collinson, M.E., Hooker, J.J., Gröcke, D.R., 2003. Cobham Lignite Bed and penecontemporaneous macrofloras of southern England: a record of vegetation and fire across the Paleocene-Eocene Thermal Maximum. In: Wing, S.L., Gingerich, P.D., Schmitz, B., Thomas, E. (Eds.), Causes and Consequences of Globally Warm Climates in the Early Paleogene. The Geological Society of America, Boulder, pp. 333-349.

Collinson, M.E., Steart, D.C., Scott, A.C., Glasspool, I.J., Hooker, J.J., 2007. Episodic fire, runoff and deposition at the Palaeocene-Eocene boundary. Journal of the Geological Society, London 164, 87-97.

Copper, P., 1988. Ecological succession in Phanerozoic reef ecosystems: is it real? Palaios 3 , $136-152$.

Cramer, B.S., Kent, D.V., 2005. Bolide summer: the Paleocene/Eocene Thermal Maximum as a response to an extraterrestrial trigger. Palaegeography, Palaeoclimatology, Palaeoecology 224, 144-166.

Crouch, E.M., Brinkhuis, H., 2005. Environmental change across the Paleocene-Eocene transition from eastern New Zealand: a marine palynological approach. Marine Micropaleontology 56, 138-160.

Crouch, E.M., Heilmann-Clausen, C., Brinkhuis, H., Morgans, H.E.G., Rogers, K.M., Egger, H., Schmitz, B., 2001. Global dinoflagellate event associated with the late Paleocene Thermal Maximum. Geology 29, 315-318.

Crouch, E.M., Dickens, G.R., Brinkhuis, H., Aubry, M.P., Hollis, C.J., Rogers, K.M., Visscher, H., 2003. The Apectodinum acme and terrestrial discharge during the PaleoceneEocene Thermal Maximum: new palynological, geochemical and calcareous nannoplankton observations at Tawanui, New Zealand. Palaeogeography, Palaeoclimatology, Palaeoecology 194, 1-17.

Demicco, R.V., Lowenstein, T.K., Hardie, L.A., 2003. Atmospheric $p \mathrm{CO}_{2}$ since $60 \mathrm{Ma}$ from records of seawater $\mathrm{pH}$, calcium, and primary carbonate mineralogy. Geology 31, 793-796.

D'Hondt, S., Arthur, M.A., 1996. Late Cretaceous oceans and the cool tropic paradox. Science 271, 1838-1841.

Dickens, G.R., O'Neil, J.R., Rea, D.K., Owen, R.M., 1995. Dissociation of oceanic methane hydrate gas as a cause of the carbon isotope excursion at the end of the Paleocene. Paleoceanography 10, 965-971.

Drobne, K., Ogorelec, B., Plenicar, M., Zucchi-Stolfa, M.L., Turnsek, D., 1988. Maastrichtian, Danian and Thanetian beds in Dolenja Vas (NW Dinarides, Yugoslavia). Mikrofacies, foraminifers, rudists and corals. Razprave 29, 147-224.

Dutton, A., Lohmann, K.C., Leckie, R.M., 2005. Insights from the Paleogene tropical Pacific: foraminiferal stable isotope and element results from Site 1209, Shatsky Rise. Paleoceanography 20, PA3004 doi:101029/2004PA001098.

Egger, H., Fenner, J., Heilmann-Clausen, C., Rögl, F., Sachsenhofer, R.F., Schmitz, B., 2003. Paleoproductivity of the northwestern Tethyan margin (Anthering Section, Austria) across the Paleocene-Eocene transition. In: Wing, S.L., Gingerich, P.D., Schmitz, B. Thomas, E. (Eds.), Causes and Consequences of Globally Warm Climates in the Early Paleogene. The Geological Society of America, Boulder, pp. 133-146.

Eichenseer, H., Luterbacher, H., 1992. The marine Paleogene of the Tremp Region (NE Spain) depositional sequences, facies history, biostratigraphy and controlling factors. Facies 27 119-152.

Ernst, S.R., Guasti, E., Dupuis, C., Speijer, R.P., 2006. Environmental perturbation in the southern Tethys across the Paleocene/Eocene boundary (Dababiya, Egypt): foraminiferal and clay mineral records. Marine Micropaleontology 60, 89-111.

Fagerstrom, J.A., 1987. The evolution of reef comunities. Wiley. 600pp.

Fitt, W.K., Brown, B.E., Warner, M.E., Dunne, R.P., 2001. Coral bleaching: interpretation of thermal tolerance limits and thermal thresholds in tropical corals. Coral Reefs 20, 51-65.

Fletcher, B.J., Brentnall, S.J., Anderson, C.W., Berner, R.A., Beerling, D.J., 2008. Atmospheric carbon dioxide linked with Mesozoic and early Cenozoic climate changes. Nature Geoscience 1, 43-48.

Fleury, J.J., Bignot, G., Blondeau, A., Poignant, A., 1985. Biogéographie de Foraminifères benthiques téthysiens du Sénonien à l'Éocène supérieur. Bulletin de la Societé géologique de France 8, 757-770.

Flügel, E., Kiessling, W., 2002. Patterns of Phanerozoic reef crises. In: Kiessling, W., Flügel, E., Golonka, J. (Eds.), Phanerozoic Reef Patterns. SEPM, Tulsa, pp. 691-733.

Forster, A., Schouten, S., Moriya, K., Wilson, P.A., Sinninghe Damste, J.S., 2007. Tropical warming and intermittent cooling during the Cenomanian/Turonian oceanic anoxic event 2: sea surface temperature records from the equatorial Atlantic. Paleoceanography 22 doi:10.1029/2006PA001349.

Francis, J.E., Poole, I., 2002. Cretaceous and early Tertiary climates of Antarctica: evidence from fossil wood. Palaeogeography, Palaeoclimatology, Palaeoecology 182, 47-64.

Guinotte, J.M., Buddemeier, R.W., Kleypas, J.A., 2003. Future coral reef habitat marginality: temporal and spatial effects of climate change in the Pacific basin. Coral Reefs 22, 551-558.

Gattuso, J.P., Buddemeier, R.W., 2000. Calcification and $\mathrm{CO}_{2}$. Nature 407, 311-313.
Gavrilov, Y.O., Shcherbinina, E.A., Oberhänsli, H., 2003. Paleocene-Eocene boundary events in the northeastern Peri-Tethys. In: Wing, S.L., Gingerich, P.D., Schmitz, B. Thomas, E. (Eds.), Causes and Consequences of Globally Warm Climates in the Early Paleogene. The Geological Society of America, Boulder, pp. 147-168.

Geel, T., 2000. Recognition of stratigraphic sequences in carbonate platform and slope deposits: Empirical models based on microfacies analysis of Palaeogene deposits in southeastern Spain. Palaeogeography, Palaeoclimatology, Palaeoecology 155, 211-238.

Gingerich, P.D., 2006. Environment and evolution through the Paleocene-Eocene Thermal Maximum. Trends in Ecology and Evolution 21, 246-253.

Gingerich, P.D., Clyde, W.C., 2001. Overview of mammalian biostratigraphy in the Paleocene-Ecoene Fort Union and Willwood Formations of the Bighorn and Clarks Fork Basins. University of Michigan Papers on Paleontology 33, 1-14.

Gibbs, S.J., Bown, P.R., Sessa, J.A., Bralower, T.J., Wilson, P.A., 2006a. Nannoplankton extinction and origination across the Paleocene-Eocene Thermal Maximum. Science 314, 1770-1773.

Gibbs, S.J., Bralower, T.J., Bown, P.R., Zachos, J.C., Bybell, L.M., 2006b. Shelf and openocean calcareous phytoplankton assemblages across the Paleocene-Eocene Thermal Maximum: implications for global productivity gradients. Geology 34, 233-236.

Giusberti, L., Rio, D., Agnini, C., Backman, J., Fornaciari, E., Tateo, F., Oddone, M., 2007. Mode and tempo of the Paleocene-Eocene Thermal Maximum in an expanded section from the Venetian pre-Alps. GSA Bulletin 119, 391-412.

Glynn, P.W., 2000. El Niño-Southern Oscillation mass mortalities of reef corals: a mode of high temperature marine extinctions? In: Insalaco, E., Skelton, P.W., Palmer, T.J (Eds.), Carbonate Platform Systems: Components and Interactions. Geological Society, London, London, pp. 117-133.

Goldberg, J., Wilkinson, C., 2004. Global threats to coral reefs: coral bleaching, globa climate change, disease predator plagues, and invasive species. In: Wilkinson, C. (Ed.), Status on Coral Reefs of the World: 2004 Volume 1. Australian Institute of Marine Science, pp. 67-92. http://www.gcrmn.org/Status2004.asp.

Gradstein, F., Ogg, J., Smith, A. (Eds.), 2004. A Geologic Time Scale 2004. Cambridge University Press. 1-589 pp.

Greenwood, D.R., Wing, S.L., 1995. Eocene continental climates and latitudinal temperature gradients. Geology 23, 1044-1048.

Hallock, P., 1987. Fluctuation in the trophic resource continuum: a factor in global diversity cycles? Paleoceanography 2, 457-471.

Hallock, P., 1988a. The role of nutrient availability in bioerosion: consequences to carbonate buildups. Palaeogeography, Palaeoclimatology, Palaeoecology 63, 275-291.

Hallock, P., 1988b. Diversification in Algal Symbiont-Bearing Foraminifera: a Response to Oligotrophy?. Revue Paléobiol. Genève Vol. Spec. No. 2: 789-797.

Hallock, P., 2000. Symbiont-bearing foraminifera: harbingers of global change? Micropaleontology 46 (supplement 1), 95-104.

Hallock, P., 2005. Global change and modern coral reefs: new opportunities to understand shallow-water carbonate depositional processes. Sedimentary Geology 175, 19-33.

Hallock, P., Schlager, W., 1986. Nutrient excess and the demise of coral reefs and carbonate platforms. Palaios 1, 389-398.

Hallock, P., Premoli Silva, I., Boersma, A., 1991. Similarities between planktonic and larger foraminiferal evolutionary trends through Paleogene paleoceanographic changes. Palaeogeography, Palaeoclimatology, Palaeoecology 83, 49-64.

Hallock, P., Williams, D.E., Fisher, E.M., Toler, S.K., 2006. Bleaching in foraminifera with algal symbionts: implications for reef monitoring and risk assessment. Anuário do Instituto de Geociêcias 29, 108-128.

Hansen, J., Sato, M., Ruedy, R., Kharecha, P., Lacis, A., Miller, R., Nazarenko, L., Lo, K., Schmidt, G.A., Russell, G., Aleinov, I., Bauer, S., Baum, E., Cairns, B., Canuto, V., Chandler, M., Cheng, Y., Cohen, A., Del Genio, A., Faluvegi, G., Fleming, E., Friend, A., Hall, T., Jackman, C., Jonas, J., Kelley, M., Kiang, N.Y., Loch, D., Labow, G., Lerner, J., Menon, S., Novakov, T. Oinas, V., Perlwitz, Ja., Perlwitz, Ju., Rind, D., Romanou, A., Schmunk, R., Shindell, D. Stone, P., Sun, S., Streets, D., Tausnev, N., Thresher, D., Unger, N., Yao, M., Zhang, S., 2007. Dangerous human-made interference with climate: a GISS modelE study. Atmospheric Chemistry and Physics 7, 2287-2312.

Haq, B.U., Hardenbol, J., Vail, P., 1987. Chronology of fluctuating sea levels since the triassic. Science 235, 1156-1167.

Hardenbol, J., Thierry, H., Farley, M.B., Jacquin, T., de Graciansky, P., Vail, P.R., 1998. Mesozoic and Cenozoic sequence chronostratigraphic framework of European basins. In: de Graciansky, P.C., Hardenbol, J., Jacquin, T., Vail, P.R. (Eds.), Mesozoic and Cenozoic Sequence Stratigraphy of European Basins. . SEPM Spec. Publ., vol. 60. SEPM, Tulsa, pp. 3-13.

Harrington, G.J., Jaramillo, C.A., 2007. Paratropical floral extinction in the Late Palaeocene-Early Eocene. Journal of the Geological Society, London 164, 323-332.

Harrington, G.J., Kemp, S.J., Koch, P.L., 2004. Palaeocene-Eocene paratropical floral change in North America: responses to climate change and plant immigration. Journal of the Geological Society, London 161,173-184.

Harvell, C.D., Mitchell, C.E., Ward, J.R., Altizer, S., Dobson, A.P., Ostfeld, R.S., Samuel, M.D. 2002. Climate warming and disease risks for terrestrial and marine biota. Science 296 2158-2162.

Hay, W.W., DeConto, R., Wold, C.N., Wilson, K.M., Voigt, S., Schulz, M., Wold-Rossby, A. Dullo, W.C., Ronov, A.B., Balukhovsky, A.N., Soeding, E., 1999. Alternative global Cretaceous paleogeography. In: Barrera, E., Johnson, C. (Eds.), The Evolution of Cretaceous Ocean/Climate Systems. . Geological Society of America Special Paper, vol. 332. Geological Society of America, Boulder, pp. 1-47.

Herbig, H.G., 1986. Lithostratigraphisch-fazielle Untersuchungen im marinen Alttertiär südlich des zentralen Hohen Atlas (Marokko). Berliner geowisschaftliche Abhandlungen (A) 66, 343-380.

Higgins, J.A., Schrag, D.P., 2006. Beyond methane: towards a theory for the Paleocene-Eocene Thermal Maximum. Earth and Planetary Science Letters 245, 523-537.

Hoegh-Guldberg, O., 1999. Climate change, coral bleaching and the future of the world's coral reefs. Marine Freshwater Research 50, 839-866. 
Hoegh-Guldberg, O., 2005. Low coral cover in a high- $\mathrm{CO}_{2}$ world. Journal of Geophysical Research 110. doi:10.1029/2004JC002528.

Hoegh-Guldberg, O., Mumby, P.J., Hooten, A.J., Steneck, R.S., Greenfield, P., Gomez, E., Harvell, C.D., Sale, P.F., Edwards, A.J., Caldeira, K., Knowlton, N., Eakin, C.M., IglesiasPrieto, R., Muthiga, N., Bradbury, R.H., Dubi, A., Hatziolos, M.E., 2007. Coral reefs under rapid climate change and ocean acidification. Science 318, 1737-1742.

Hottinger, L., 1960. Recherches sur les Alvéolines du Palécène et de l'Eocène. Schweizerische Palaeontologische Abhandlungen 75/76, 1-243.

Hottinger, L., 1971. Larger foraminifera common to Mediterranean and Indian Paleocene and Eocene formations. Ann. Inst. Geol. Publ. Hungary 54 (4/1), 145-151.

Hottinger, L., 1973. Selected Paleogene larger foraminifera. In: Hallam, A. (Ed.), Atlas of Palaeobiogeography. Elsevier, Amsterdam, pp. 443-452.

Hottinger, L., 1982. Larger foraminifera, giant cells with a historical background. Naturwissenschaften 69, 361-371.

Hottinger, L., 1983. Processes determining the distribution of larger foraminifera in space and time. Utrecht Micropaleontological Bulletins 30, 239-253.

Hottinger, L., 1997. Shallow benthic foraminiferal assemblages as signals for depth of their deposition and their limitations. Bulletin de la Societé Géologique de France 168, 491-505.

Hottinger, L., 1998. Shallow Benthic Foraminifera at the Paleocene-Eocene Boundary. Strata, Serie 19: 61-64.

Hottinger, L., 2001. Learning from the past? In: Box, E., Pignatti, S. (Eds.), Volume IV: The Living World. Part Two. Academic Press, San Diego, pp. 449-477.

Hottinger, L., 2006. Illustrated glossary of terms used in foraminiferal research. Carnets de Gèologie. Memoir 2, 1-126.

Hottinger, L., Schaub, H., 1960. Zur Stufeneinteilung des Paleocaens und des Eocaens. Eclogae Geologicae Helvetiae 53, 453-479.

Huber, M., Sloan, L.C., 2000. Climatic responses to tropical sea surface temperature changes on a "greenhouse" earth. Paleoceanography 15, 443-450.

Huber, M., Caballero, R., 2003. Eocene El Niño: evidence for robust tropical dynamics in the "Hothouse". Science 299, 877-881.

Huber, M., Sloan, L.C., Shellito, C., 2003. Early Paleogene oceans and climate: a fully coupled modeling approach using the NCAR CCSM. In: Wing, S.L., Gingerich, P.D., Schmitz, B., Thomas, E. (Eds.), Causes and Consequences of Globally Warm Climates in the Early Paleogene. The Geological Society of America, Boulder, pp. 25-47.

Hughes, T.P., Baird, A.H., Bellwood, D.R., Card, M., Connolly, S.R., Folke, C., Grosberg, R., Hoegh-Guldberg, O., Jackson, J.B.C., Kleypas, J., Lough, J.M., Marshall, P., Nyström, M., Palumbi, S.R., Pandolfi, J.M., Rosen, B., Roughgarden, J., 2003. Climate change, human impacts, and the resilience of coral reefs. Science 301, 929-933.

Inan, N., Tasli, K., Inan, S., 2005. Laffitteina from the Maastrichtian-Paleocene shallow marine carbonate successions of the Eastern Pontides (NE Turkey): biozonation and microfacies. Journal of Asian Earth Sciences 25, 367-378.

James, N.P., 1983. Reef Environment. In: Scholle, P.A., Bebout, D.G., Moore, C.H. (Eds.), Carbonate Depositional Environments. . AAPG Memoir, vol. 33. AAPG Tulsa, pp. 345-462.

Jaramillo, C.A., 2002. Response of tropical vegetation to Paleogene warming. Paleobiology 28 , $222-243$.

Jaramillo, C.A., Dilcher, D.L., 2000. Microfloral diversity patterns of the late PaleoceneEocene interval in Colombia, northern South America. Geology 28, 815-818.

Jauhri, A.K., 1994. Carbonate buildup in the Lakadong Formation of the South Shillong Plateau, NE India: A micropaleontological perspective. In: Matteucci, R. (Ed.) Studies on Ecology and Paleoecology of Benthic Communities. . Boll. Soc. Paleont. Ital., Spect, vol. 2. Italian Paleontological Society, Modena, pp. 157-169.

Jauhri, A.K., 1996. Ranikothalia nuttalli (Davies), a distinctive early Ilerdian marker, in the Shillong Plateau. In: Pandey, J., Azmi, R.J., Bhandari, A., Dave, A. (Eds.), Contributions to XV Indian Colloquium on Micropalaeontology and Stratigraphy. Allied Printers, Dehra Dun, pp. 209-217.

Jauhri, A.K., 1998. Miscellanea Pfender, 1935 (foraminiferida) from the South Shillong region, N.E. India. Journal of the Palaeontological Society of India 43, 73-83.

Jauhri, A.K., Agarwal, K.K., 2001. Early Palaeogene in the south Shillong Plateau, NE India: local biostratigraphic signals of global tectonic and oceanic changes. Palaeogeography, Palaeoclimatology, Palaeoecology 168, 187-203.

Jauhri, A.K., Misra, P.K., Kishore, S., Singh, S.K., 2006. Larger foraminiferal and calcareous algal facies in the Lakadong Formation of the South Shillong Plateau, NE India. Journal of the Palaeontological Society of India 51, 51-61.

Jenkyns, H.C., Wilson, P.A., 1999. Stratigraphy, paleoceanography, and evolution of Cretaceous Pacific guyots: relics from a greenhouse earth. American Journal of Science 299, 341-392.

Jiang, S., Wise, S.W., 2006. Surface-water chemistry and fertility variations in the tropical Atlantic across the Paleocene/Eocene Thermal Maximum as evidenced by calcareous nannoplankton from ODP Leg 207, Hole 1259B. Revue de Micropaléontologie 49, $227-244$.

Jurkovsek, B., Toman, M., Ogorelec, B., Sribar, L., Drobne, K., Poljak, M., Sribar, L., 1996. Geological Map of the Southern Part of the Trieste-Komen Plateau. Institut za geologijo, geotehniko in geofiziko, Ljubljana. 1-143 pp.

Katz, M.E., Cramer, B.S., Mountain, G.S., Katz, S., Miller, K.G., 2001. Uncorking the bottle: What triggered the Paleocene/Eocene Thermal Maximum methane release? Paleoceanography 16, 549-562.

Kauffman, E.G., Johnson, C.C., 1988. The morphological and ecological evolution of middle and upper Cretaceous reef-building rudists. Palaios 3, 194-216.

Kazmer, M., Dunkl, I., Frisch, W., Kuhlemann, J., Ozsvart, P., 2003. The Palaeogene forearc basin of the Eastern Alps and Western Carpathians: subduction erosion and basin evolution. Journal of the Geological Society, London 160, 413-428.

Kelly, D.C., 2002. Response of Antarctic (ODP Site 690) planktonic foraminifera to the Paleocene-Eocene Thermal Maximum: faunal evidence for ocean/climate change. Paleoceanography 17, 1071, doi:1029/2002PA000761.
Kelly, D.C., Bralower, T.J., Zachos, J.C., 1998. Evolutionary consequences of the latest Paleocene Thermal Maximum for tropical planktonic foraminifera. Palaeogeography, Palaeoclimatology, Palaeoecology 141, 139-161.

Kelly, D.C., Zachos, J.C., Bralower, T.J., Schellenberg, S.A., 2005. Enhanced terrestrial weathering/runoff and surface ocean carbonate production during the recovery stages of the Paleocene-Eocene Thermal Maximum. Paleoceanography 20, Pa4023. doi:10.1029/2005PA001163.

Kent, D.V., Cramer, B.S., Lanci, L., Wang, D. Wright, J.D., van der Voo, R 2003. A case for a comet impact trigger for the Paleocene/Eocene Thermal Maximum and carbon isotope excursion. Earth and Planetary Science Letters 211, 13-26.

Kiessling, W., 2001. Paleoclimatic significance of Phanerozoic reefs. Geology 29, 751-754. Kiessling. W. 2002. Secular variations in the Phanerozoic reef ecosystem. In: Kiessling, W., Flügel, E., Golonka, J. (Eds.), Phanerozoic Reef Patterns. SEPM, Tulsa, pp. 625-690.

Kiessling, W., Baron-Szabo, R.C., 2004. Extinction and recovery patterns of scleractinian corals at the Cretaceous-Tertiary boundary. Palaegeography, Palaeoclimatology, Palaeoecology 214, 195-223.

Kiessling, W., Flügel, E., Golonka, J., 2000. Fluctuations in the carbonate production of Phanerozoic reefs. In: Insalaco, E., Skelton, P.W., Palmer, T.J. (Eds.), Carbonate Platform Systems: Components and Interactions. Geological Society, London, pp. 191-215.

Kleypas, J.A., Buddemeier, R.W., Archer, D., Gattuso, J.P., Langdon, C., Opdyke, B.N., 1999. Geochemical consequences of increased atmospheric carbon dioxide on coral reefs. Science 284, 118-120.

Kleypas, J.A., Buddemeier, R.W., Gattuso, J.P., 2001. The future of coral reefs in an age of global change. International Journal of Earth Sciences 90, 426-437.

Kleypas, J.A., Danabasoglu, G., Lough, J.M., 2008. Potential role of the ocean thermostat in determing regional differences in coral bleaching events. Geophysical Research Letters 35. doi:10.1029/2007GL032257.

Kobashi, T., Grossman, E.L., Yancey, T.E., Dockery III, D.T., 2001. Reevalution of conflicting Eocene tropical temperature estimates: Molluskan oxygen isotope evidence for warm low latitudes. Geology 29, 983-986.

Köhler, E., Salaj, J., Bucek, S., 1993. Paleogeographical development of the Myjava sedimentary area (western Slovakia) during the existance of the Paleocene reef complex. Geologica Carpathica 44, 373-380.

Kroon, D., Zachos, J.C., Leg 208 Scientific Party, 2007. Leg 208 synthesis: Cenozoic climate cycles and excursions. In: Kroon, D., Zachos, J.C., Richter, C. (Eds.), Proc. ODP, Sci. Results, 208, pp. 1-55. doi:10.2973/odp.proc.sr.208.201.2007.

Kump, L.R., 2001. Chill taken out of the tropics. Nature 413, 470-471.

Kurtz, A.C., Kump, L.R., Arthur, M.A., Zachos, J.C., Paytan, A., 2003. Early Cenozoic decoupling of the global carbon and sulfur cycles. Paleoceanography 18, 1090. doi:10.1029/2003PA000908.

Kuss, J., Scheibner, C., Gietl, R., 2000. Carbonate platform to basin transition along an Upper Cretaceous to Lower Tertiary Syrian Arc Uplift, Galala Plateaus, Eastern Desert, Egypt. GeoArabia 5, 405-424.

Langer, M.R., 2008. Assessing the contribution of foraminiferan protists to global ocean carbonate production. Journal of Eucaryot. Microbiol. 55, 163-169.

Langer, M.R., Hottinger, L., 2000. Biogeography of selected "larger" foraminifera. Micropaleontology 46 (supplement 1), 105-126.

Lee, J.J., McEnery, M.E., Kahn, E.G., Schuster, F.L., 1979. Symbiosis and the evolution of larger foraminifera. Micropaleontology 25, 118-140.

Leppig, U., 1988. Structural analysis and taxonomic revision of Miscellanea, Paleocene, larger foraminifera. Eclogae Geologicae Helvetiae 81, 689-721.

LeRoy, L.W., 1953. Biostratigraphy of the Maqfi section, Egypt. Memoir Geological Society America 54, 1-73.

Lopez-Perez, R.A., 2005. The Cenozoic hermatypic corals in the eastern Pacific: history of research. Earth-Science Reviews 72, 67-87.

Loucks, R.G., Moody, R.T.J., Bellis, J.K., Brown, A.A., 1998. Regional depositional setting and pore network systems of the El Garia Formation (Metlaoui Group, Lower Eocene), offshore Tunisia. In: Macgregor, D.S., Moody, R.T.J., Clark-Lowes, D.D. (Eds.), Petroleum Geology of North Africa. . Spec. Publ., vol. 132. Geological Society, London, pp. 355-374. London.

Lourens, L.J., Sluijs, A., Kroon, D., Zachos, J.C., Thomas, E., Röhl, U., Bowles, J., Raffi, I., 2005. Astronomical pacing of late Palaeocene to early Eocene global warming events. Nature 435, 1083-1087.

Luterbacher, H.P., Ali, J.R., Brinkhuis, H., Gradstein, F.M., Hooker, J.J., Monechi, S., Ogg.J.G. Powell, J., Röhl, U., Sanfilippo, A., Schmitz, B., 2004. The Paleogene period. In: Gradstein, F., Ogg, J., Smith, A. (Eds.), A Geologic Time Scale 2004. Cambridge University Press, Cambridge, pp. 384-408.

Maas, M.C., Anthony, M.R.L., Gingerich, P.D., Gunnell, G.F., Krause, D.W., 1995. Mammalian generic diversity and turnover in the Late Paleocene and Early Eocene of the Bighorn and Crazy Mountains Basins, Wyoming and Montana (USA). Palaeogeography, Palaeoclimatology, Palaeoecology 115, 181-207.

MacGregor, D.S., Moody, R.T.J., 1998. Mesozoic and Cenozoic petroleum systems of North Africa. In: Macgregor, D.S., Moody, R.T.J., Clark-Lowes, D.D. (Eds.), Petroleum Geology of North Africa. . Spec. Publ., vol. 132. Geological Society, London, pp. 201-216. London.

Maclennan, J., Jones, S.M., 2006. Regional uplift, gas hydrate dissociation and the origins of the Paleocene-Eocene Thermal Maximum. Earth and Planetary Science Letters 245, $65-80$.

Marzouk, A.M., Scheibner, C., 2003. Calcareous nannoplankton biostratigraphy and paleoenvironment of the late Cretaceous-Paleogene of the Galala Mountains, Eastern Desert, Egypt. Courier Forschungsinstitut Senckenberg 244, 11-35.

Miller, K.G., Wright, J.D., Browning, J.V., 2005a. Visions of ice sheets in a greenhouse world. Marine Geology 217, 215-231.

Miller, K.G., Kominz, M.A., Browning, J.V., Wright, J.D., Mountain, G.S., Katz, M.E., Sugarman, P.J., Cramer, B.S., Christie-Blick, N., Pekar, S.F., 2005b. The Phanerozoic record of global sea-level change. Science 310, 1293-1298. 
Misra, P.K., Jauhri, A.K., Kishore, S., Singh, S.K., 2002. Calcareous algae from the Lakadong Formation of the South Shillong Plateau, NE India. Revue de Paleobiologie 21, 717-734.

Moody, R.T.J., 1987. The Ypresian carbonates of Tunisia - a model of foraminiferal facies distribution. In: Hart, M.B. (Ed.), Micropalaeontology of Carbonate Enviroments. British Micropalaeontology Society, Chichester, pp. 82-92.

Moran, K., Backman, J., Brinkhuis, H., Clemens, S.C., Cronin, T., Dickens, G.R., Eynaud, F., Gattacceca, J., Jakobson, M., Jordan, R.W., Kaminski, M., King, J., Koc, N., Krylov, A. Martinez, N., Matthiessen, J., McInroy, D., Moore, T.C., Onodera, J., O'Regan, M. Pälike, H., Rea, B., Rio, D., Sakamoto, T., Smith, D.C., Stein, R., John, K.S., Suto, I., Suzuki, N., Takahashi, K., Watanabe, M., Yamamoto, M., Farrel, J., Frank, M., Kubik, P., Jokat, W., Kristoffersen, Y., 2006. The Cenozoic palaeoenvironment of the Arctic Ocean. Nature 441, 601-605.

Morsi, A.M.M. and Scheibner, C., in press. Paleocene-Early Eocene ostracodes from the Southern Galala Plateau (Eastern Desert, Egypt): taxonomy, impact of paleobathymetric changes. Revue de Micropaléontologie. doi:10.1016/j.revmic.2007.08.

Moussavian, E., 1984. Die Gosau- und Alttertiär-Gerölle der Angerberg-Schichten (Höheres Oligozän, Unterinntal, Nördliche Kalkalpen). Facies 10,1-86.

Moussavian, E., Vecsei, A., 1995. Paleocene reef sediments from the Maiella carbonate platform, Italy. Facies 32, 213-222.

Mutterlose, J., Linnert, C., Norris, R., 2007. Calcareous nannofossils from the PaleoceneEcoene Thermal Maximum of the equatorial Atlantic(ODP Site 1260B): Evidence for tropical warming. Marine Micropaleontology 65, 13-31.

Mresah, M.H., 1993. Facies patterns and statal geometries: clues to the nature of the platform margin during the Paleocene, northeast Sirte Basin, Libya. Sedimentary Geology 84, 149-167.

Nicolo, M.J., Dickens, G.R., Hollis, C.J., Zachos, J.C., 2007. Multiple early Eocene hyperthermals: Their sedimentary expression on the New Zealand continental margin and in the deep sea. Geology 35, 699-702.

Nagappa, Y., 1959. Foraminiferal biostratigraphy of the Cretaceous-Eocene succession in the India-Pakistan-Burma region. Micropaleontology 5, 145-192.

Nolan, S.C., Skelton, P.W., Clissold, B.P., Smewing, J.D., 1990. Maastrichtian to early Tertiary stratigraphy and palaeogeography of the Central and Northern Oman Mountains. In: Robertson, A.H., Searle, M.P., Ries, A.C. (Eds.), The Geology and Tectonics of the Oman Region. Geological Society, London, pp. 495-519.

Norris, R.D., Röhl, U., 1999. Carbon cycling and chronology of climate warming during the Palaeocene/Eocene transition. Nature 401, 775-778.

Orr, J.C., Fabry, V.J., Aumont, O., Bopp, L., Doney, S.C., Feely, R.A., Gnanadesikan, A., Gruber, N., Ishida, A., Joos, F., Key, R.M., Lindsay, K., Maier-Reimer, E., Matear, R., Monfray, R., Mouchet, A., Najjar, R.G., Plattner, G.K., Rodgers, K.B., Sabine, C.L. Sarmiento, J.L., Schlitzer, R., Slater, R.D., Totterdell, I.A.J., Weirig, M.F., Yamanaka, Y., Yool, A., 2005. Anthropogenic ocean acidification over the twenty-first century and its impact on calcifying organisms. Nature 437, 681-686.

Orue-Etxebarria, X., Pujalte, V., Bernaola, G., Apellaniz, E., Baceta, J.I., Payros, A., NunezBetelu, K., Serra-Kiel, J., Tosquella, J., 2001. Did the Late Paleocene Thermal Maximum affect the evolution of larger foraminifers? Evidence from calcareous plankton of the Campo Section (Pyrenees, Spain). Marine Micropaleontology 41, 45-71.

Özgen-Erdem, N., Inan, N., Ajyazi, M., Tunoglu, C., 2005. Benthonic foraminiferal assemblages and microfacies analysis of Paleocene-Eocene carbonate rocks in the Kastamonu region, Northern Turkey. Journal of Asian Earth Sciences 25, 403-417.

Özgen-Erdem, N., Akyazi, M., Karabsoglu, A., 2007. Biostratigraphic interpretation and systematics of Alveolina assemblages from the Ilerdian-Cuisian limestones of Southern Eskisehir, Central Turkey. Journal of Asian Earth Sciences 29, 911-927.

Pagani, M., Zachos, J.C., Freeman, K.H., Tipple, B., Bohaty, S., 2005. Marked decline in atmospheric carbon dioxide concentrations during the Paleogene. Science 309, 600-603.

Pagani, M., Caldeira, K., Archer, D., Zachos, J.C., 2006a. An ancient carbon mystery. Science 314, 1556-1557.

Pagani, M., Pedentchouk, N., Huber, M., Sluijs, A., Schouten, S., Brinkhuis, H., Sinninghe Damste, J.S., Dickens, G.R., 2006b. Arctic hydrology during global warming at the Palaeocene/Eocene Thermal Maximum. Nature 442, 671-675.

Pak, D.K., Miller, K.G., 1992. Paleocene to Eocene benthic foraminiferal isotopes and assemblages: implications for deep water ciculation. Paleoceanography 7, 405-422.

Pancost, R.D., Steart, D.S., Handley, L., Collinson, M.E., Hooker, J.J., Scott, A.C., Grassineau, N.V., Glasspool, I.J., 2007. Increased terrestrial methane cycling at the PaleoceneEocene Thermal Maximum. Nature 449, 332-335.

Pandolfi, J.M., Bradbury, R.H., Sala, E., Hughes, T.P., Bjorndal, K.A., Cooke, R.G., McArdle, D., McClenachan, L., Newman, M.J.H., Paredes, G., Warner, R.R., Jackson, J.B.C., 2003. Global trajectories of the long-term decline of coral reef ecosystems. Science 301, 955-958.

Payros, A., Pujalte, V., Baceta, J.I., Bernaola, G., Orue-Etxebarria, X., Apellaniz, E., Caballero, F., Ferrandez, C., 2000. Lithostratigraphy and sequence stratigraphy of the upper Thanetian to middle Ilerdian strata of the Campo section (southern Pyrenees, Spain): revision and new data. Rev. Soc. Geol. Espana 13, 213-226.

Pearson, P.N., Palmer, M.R., 2000. Atmospheric carbon dioxide concentrations over the past 60 million years. Nature 406, 695-699.

Pearson, P.N., Ditchfield, P.W., Singano, J., Harcourt-Brown, K.G., Nicholas, C.J., Olsson, R.K., Shackleton, N.J., Hall, M.A., 2001. Warm tropical sea surface temperatures in the Late Cretaceous and Eocene epochs. Nature 413, 481-487.

Pearson, P.N., van Dongen, B.E., Nicholas, C.J., Pancost, R.D., Schouten, S., Singano, J.M., Wade, B.S., 2007. Stable warm tropical climate through the Eocene epoch. Geology $35,211-214$.

Perrin, C., 2002. Tertiary: the emergence of modern reef ecosystems. In: Kiessling, W. Flügel, E., Golonka, J. (Eds.), Phanerozoic Reef Patterns. SEPM, Tulsa, pp. 587-621.

Petrizzo, M.R., 2007. The onset of the Paleocene-Eocene Thermal Maximum (PETM) at Sites 1209 and 1210 (Shatsky Rise, Pacific Ocean) as recorded by planktonic foraminifera. Marine Micropaleontology 63, 187-200.
Philip, J., 2003. Peri-Tethyan neritic carbonate areas: distribution through time and driving factors. Palaeogeography, Palaeoclimatology, Palaeoecology 196, 19-37.

Pignatti, J.S., 1991. Hypothesis testing in paleontology: the Paleocene-Eocene large foraminiferal record and eustatic sea level changes. Annali di Botanica 49, 217-226.

Pignatti, J.S., 1994. Paleobiogeography of Paleogene Larger Foraminifera from the Mediterranean Tethys to the Western Pacific Using Parsimony Analysis: a Preliminary Attempt. Boll. Soc. Paleont. Ital., Spec., vol. 2, pp. 243-252.

Plaziat, J.C., Perrin, C. 1992. Multikilometer-sized reefs built by foraminifera (Solenomeris) from the early Eocene of the Pyrenean domain (S. France, N. Spain): Palaeoecologic relations with coral reefs. Palaeogeography, Palaeoclimatology, Palaeoecology 96, 195-231.

Pomar, L., Hallock, P., 2007. Changes in coral-reef structure through the Miocene in the Mediterranean province: adaptive versus environmental influence. Geology 35, 899-902.

Pujalte, V., Robles, S., Robador, A., Baceta, J.I., Orue-Etxebarria, X., 1993. Shelf-to-basin Paleocene palaeogeography and depositional sequences, western Pyrenees, north Spain. In: Posamentier, H.W., Summerhayes, C.P., Haq, B.U., Allen, G.P. (Eds.), Sequence stratigraphy and facies association. Special Publication, International Association Sedimentologists. Blackwell, Oxford, pp. 369-395.

Pujalte, V., Orue-Etxebarria, X., Schmitz, B., Tosquella, J., Baceta, J.I., Payros, A., Bernaola G., Caballero, F., Apellaniz, E., 2003a. Basal Ilerdian (earliest Eocene) turnover of larger foraminifera: Age constraints based on calcareous plankton and $d^{13} \mathrm{C}$ isotopic profiles from new southern Pyrenean sections (Spain). In: Wing, S.L., Gingerich, P.D., Schmitz, B., Thomas, E. (Eds.), Causes and Consequences of Globally Warm Climates in the Early Paleogene. GSA Special Paper. Geological Society of America, Boulder, pp. 205-221.

Pujalte, V., Dinares-Turell, J., Bernaola, G., Baceta, J.I., Payros, A., 2003b. A reappraisal of the position of Chron C25n in the Campo section (Huesca province, south-central Pyrenees). Geogaceta 34, 155-158.

Purton, L.M.A., Brasier, M.D. 1999. Giant protist Nummulites and its Eocene environment: Life span and habitat insights from $d^{18} \mathrm{O}$ and $d^{13} \mathrm{C}$ data from Nummulites and Venericardia, Hampshire basin, UK. Geology 27, 711-714.

Racey, A., 1994. Biostratigraphy and palaeobiogeographic significance of Tertiary nummulitids (foraminifera) from northern Oman. In: Simmons, M.D. (Ed.), Micropalaeontology and Hydrocarbon Exploration in the Middle East. Chapman \& Hall, London, pp. 343-367.

Racz, L., 1979. Paleocene carbonate development of Ras al Hamra, Oman. Bull. Centres Rech. Explor.-Prod. Elf-Aquitaine 3, 767-779.

Rasser, M.W., Scheibner, C., Mutti, M., 2005. A paleoenvironmental standard section for Lower Ilerdian tropical carbonate factories (Pyrenees, Spain; Corbieres, France). Facies 51, 217-232.

Ravizza, G., Norris, R.N., Blusztajn, J., 2001. An osmium isotope excursion associated with the late Paleocene Thermal Maximum: evidence of intensified chemical weathering. Paleoceanography 16, 155-163.

Rea, D.K., Zachos, J.C., Owen, R.M., Gingerich, P.D., 1990. Global change at the PaleoceneEocene boundary: climatic and evolutionary consequences of tectonic events Palaegeography, Palaeoclimatology, Palaeoecology 79, 117-128.

Ries, J.B., Stanley, S.M., Hardie, L.A., 2006. Scleractinian corals produce calcite, and grow more slowly, in artificial Cretaceous seawater. Geology 34, 525-528.

Robert, C., Chamley, H., 1991. Development of early Eocene warm climates, as inferred from clay mineral variations in oceanic sediments. Palaeogeography, Palaeoclimatology, Palaeoecology 89, 315-331.

Robert, C., Kennett, J.P., 1994. Antarctic subtropical humid episode at the PaleoceneEocene boundary: clay-mineral evidence. Geology 22, 211-214.

Roche, D.M., Donnadieu, Y., Puceat, E., Paillard, D., 2006. Effect of changes in $d^{18} \mathrm{O}$ of the surface ocean on estimated sea surface tempertures in past warm climate. Paleoceanography 21, PA2023. doi:10.1029/2005PA001220.

Royer, D.L., 2003. Estimating latest Cretaceous and Tertiary atmospheric $\mathrm{CO}_{2}$ from stomatal indices. In: Wing, S.L., Gingerich, P.D., Schmitz, B., Thomas, E. (Eds.), Causes and Consequences of Globally Warm Climates in the Early Paleogene. The Geological Society of America, Boulder, pp. 79-93.

Royer, D.L., 2006. $\mathrm{CO}_{2}$-forced climate thresholds during the Phanerozoic. Geochimica et Cosmochimica Acta 70, 5665-5675.

Royer, D.L., Wing, S.L., Beerling, D.J., Jolley, D.W., Koch, P.L., Hickey, L.J., Berner, R.A. 2001a. Paleobotanical evidence for near present-day levels of atmospheric $\mathrm{CO}_{2}$ during part of the Tertiary. Science 292, 2310-2313.

Royer, D.L., Berner, R.A., Beerling, D.J., 2001b. Phanerozoic atmospheric $\mathrm{CO}_{2}$ change: evaluating geochemical and paleobiological approaches. Earth-Science Reviews 54, 349-392.

Royer, D.L., Berner, R.A., Park, J., 2007. Climate sensitivity constrained by $\mathrm{CO}_{2}$ concentrations over the past 420 million years. Nature 446, 530-532.

Röhl, U., Westerhold, T., Monechi, S., Thomas, E., Zachos, J.C., Donner, B., 2005. The third and final Early Eocene Thermal Maximum: characteristics, timing, and mechanisms of the "X"-event. GSA Abstracts with Programs 37, 264.

Rull, V., 1999. Palaeofloristic and palaeovegetational changes across the Paleocene/ Eocene boundary in northern South America. Review of Palaeobotany and Palynology 107, 83-95.

Sahni, A., Kumar, V., 1974. Palaeogene palaeobiogeography of the Indian subcontinent Palaegeography, Palaeoclimatology, Palaeoecology 15, 209-226.

Sandberg, P.A., 1983. An oscillating trend in Phanerozic nonskeletal carbonate mineralogy. Nature 305, 19-22.

Schaub, H., 1981. Nummulites et Assilines de la Téthys paléogène. Taxonomie, phylogenèse et biostratigraphie. Schweizerische Palaeontologische Abhandlungen $104 / 105 / 106,1-238$

Scheibner, E., 1968. Contribution to the knowledge of the Palaeogene reef-complexes of the Myjava-Hricov-Haligovka Zone (West Carpathians). Mitteilungen der Bayerischen Staatssammlung für Paläontologie und historische Geologie 8, 67-97. 
Scheibner, C., Kuss, J., Marzouk, A.M., 2000. Slope sediments of a Paleocene ramp-tobasin transition in NE Egypt. International Journal of Earth Sciences 88, 708-724.

Scheibner, C., Marzouk, A.M., Kuss, J., 2001a. Maastrichtian-Early Eocene litho-biostratigraphy and palaeogeography of the northern Gulf of Suez region, Egypt. Journal of African Earth Sciences 32, 223-255.

Scheibner, C., Marzouk, A.M., Kuss, J., 2001b. Shelf architectures of an isolated Late Cretaceous carbonate platform margin, Galala Mountains (Eastern Desert, Egypt) Sedimentary Geology 145, 23-43.

Scheibner, C., Reijmer, J.J.G., Marzouk, A.M., Speijer, R.P., Kuss, J., 2003a. From platform to basin: the evolution of a Paleocene carbonate margin (Eastern Desert, Egypt) International Journal of Earth Sciences 92, 624-640.

Scheibner, C., Kuss, J., Speijer, R.P., 2003b. Stratigraphic modelling of carbonate platform-to-basin sediments (Maastrichtian to Paleocene) in the Eastern Desert, Egypt. Palaeogeography, Palaeoclimatology, Palaeoecology 200, 163-185.

Scheibner, C., Speijer, R.P., Marzouk, A.M., 2005. Larger foraminiferal turnover during the Paleocene/Eocene Thermal Maximum and paleoclimatic control on the evolution of platform ecosystems. Geology 33, 493-496.

Scheibner, C., Rasser, M.W., Mutti, M., 2007. Facies changes across the Paleocene-Eocene boundary: the Campo section (Pyrenees, Spain) revisited. Palaegeography, Palaeoclimatology, Palaeoecology 248, 145-168.

Scheibner, C., Speijer, R.P., 2008. Decline of Coral Reefs During Late Paleocene to Early Eocene Global Warming. eEarth 3, 19-26.

Scheibner, C. and Speijer, R.P., in press. Recalibration of the Tethyan Shallow-Benthic Zonation Across the Paleocene-Eocene Boundary; the Egyptian Record. Geologica Acta.

Schmitz, B., 2000. Plankton cooled a greenhouse. Nature 407, 143-144

Schmitz, B., Pujalte, V., 2003. Sea-level, humidity, and land-erosion records across the initial Eocene Thermal Maximum from a continental-marine transect in northern Spain. Geology 31, 689-692.

Schmitz, B., Pujalte, V., 2007. Abrupt increase in seasonal extreme precipitation at the Paleocene-Eocene boundary. Geology 35, 215-218.

Schmitz, B., Charisi, S.D., Thompson, E.I., Speijer, R.P., 1997. Barium, $\mathrm{SiO}_{2}$ (excess), an $\mathrm{P}_{2} \mathrm{O}_{5}$ as proxies of biological productivity in the Middle East during the Palaeocene and the latest Palaeocene benthic extinction event. Terra Nova 9, 95-99.

Schouten, S., Hopmans, E.C., Forster, A., van Breugel, Y., Kuypers, M.M.M., Sinninghe Damste, J.S., 2003. Extremely high sea-surface temperatures at low latitudes during the middle Cretaceous as revealed by archaeal membrane lipids. Geology 31, 1069-1072.

Schroeder, J.H., 1986. Diagenetic diversity in Paleocene coral knobs from the Bir Abu ElHusein Area, S Egypt. In: Schroeder, J.H., Purser, B.H.(Eds.), Reef Diagenesis. Springer, Berlin, pp. 133-158.

Schuster, F., 1996. Paleoecology of Paleocene and Eocene corals from the Kharga and Farafra Oases (Western Desert, Egypt) and the depositional history of the Paleocene Abu Tartur carbonate platform, Kharga Oasis. Tübinger Geowissenschaftliche Arbeiten A31, Tübingen. 96 pp.

Seiglie, G.A., 1987. Sea Level Changes and Cenozoic Large Foraminifera with Inner Structures Cushman Foundation for Foraminiferal Research. Spec. Publ., vol. 42, pp. 169-186.

Serra-Kiel, J., Hottinger, L., Caus, E., Drobne, K., Ferrandez, C., Jauhri, A.K., Less, G., Pavlovec, R., Pignatti, J., Samso, J.M., Schaub, H., Sirel, E., Strougo, A., Tambareau, Y, Tosquella, J., Zakrevskaya, E., 1998. Larger foraminiferal biostratigraphy of the Tethyan Paleocene and Eocene. Bulletin de la Société Géologique de France 169, 281-299.

Sexton, P.F., Wilson, P.A., Pearson, P.N., 2006a. Microstructural and geochemical perspectives on planktic foraminiferal preservation: "glass" versus "frosty". Geochemistry Geophysics Geosystems 7. doi:10.1029/2006GC001291.

Sexton, P.F., Wilson, P.A., Norris, R.D., 2006b. Testing the Cenozoic mulltisite composite $d^{18} \mathrm{O}$ and $d^{13} \mathrm{C}$ curves: new monospecific Eocene records from a single locality, Demerara Rise (Ocean Drilling Program Leg 207). Paleoceanography 21 doi:10.1029/2005PA001253.

Sewall,J.O., Sloan, L.C., 2004. Less ice, less tilt, less chill: the influence of a seasonally ice-free Arctic Ocean and reduced obliquity on early Paleogene climate. Geology 32, 477-480.

Sewall, J.O., Huber, M., Sloan, L.C., 2004. A method for using a fully coupled climate system model to generate detailed surface boundary conditions for paleoclimate modeling investigations: an early Paleogene example. Global and Planetary Change 43, 173-182.

Shellito, C.J., Sloan, L.C., Huber, M., 2003. Climate model sensitivity to atmospheric CO levels in the Early-Middle Paleogene. Palaegeography, Palaeoclimatology, Palaeoecology 193, 113-123.

Sheppard, C.R.C., 2003. Predicted recurrences of mass coral mortality in the Indian Ocean. Nature 425, 294-297.

Sirel, E., 1998. Foraminiferal Description and Biostratigraphy of the Paleocene-Lower Eocene Shallow-Water Limestones and Discussion on the Cretaceous-Tertiary Boundary in Turkey, Monography Series 2. General Directorate of the Mineral and Research and Exploration, Ankara, 1-117 pp.

Sloan, L.C., Barron, E.J., 1990. “Equable” climates during Earth history? Geology 18, 489-492

Sloan, L.C., Rea, D.K., 1995. Atmospheric carbon dioxide and early Eocene climate: general circulation modeling sensitivity study. Palaegeography, Palaeoclimatology, Palaeoecology 119, 275-292.

Sloan, L.C., Morrill, C., 1998. Orbital forcing and Eocene continental temperatures. Palaegeography, Palaeoclimatology, Palaeoecology 144, 21-35.

Sloan, L.C., Thomas, E., 1998. Global climate of the late Paleocene epoch: modeling the circumstances associated with a climatic "event”. In: Aubry, M.P., Lucas, S., Berggren, W.A. (Eds.), Late Paleocene-early Eocene climatic and biotic events in the marine and terrestrial records. Columbia University Press, New York, pp. 138-157.

Sloan, L.C., Huber, M., 2001a. North Atlantic climate variability in early Palaeogene time: a climate modelling sensitivity study. In: Kroon, D., Norris, R.D., Klaus, A. (Eds. Western North Atlantic Palaeogene and Cretaceous Palaeoceanography. . Geological Society London. London, pp. 253-272.
Sloan, L.C., Huber, M., 2001b. Eocene oceanic responses to orbital forcing on precessional time scales. Paleoceanography 16, 101-111.

Sloan, L.C., Walker, J.C.G., Moore, T.C., Rea, D.K., Zachos, J.C., 1992. Possible methaneinduced polar warming in the early Eocene. Nature 357, 320-322.

Sloan, L.C., Huber, M., Crowley, T.J., Sewall, J.O., Baum, S., 2001. Effect of sea surface temperature configuration on model simulations of "equable" climate in the Early Eocene. Palaegeography, Palaeoclimatology, Palaeoecology 167, 321-335.

Sluijs, A., Schouten, S., Pagani, M., Woltering, M., Brinkhuis, H., Sinninghe Damste, J.S., Dickens, G.R., Huber, M., Reichart, G.J., Stein, R., Matthiessen, J., Lourens, L.J., Pedentchouk, N., Backman, J., Moran, K., 2006. Subtopical arctic ocean temperatures during the Palaeocene/Eocene Thermal Maximum. Nature 441, 610-613.

Sluijs, A., Brinkhuis, H., Schouten, S., Bohaty, S.M., John, C.M., Zachos, J.C., Reichart, G.J., Crouch, E.M., Dickens, G.R., 2007. Environmental precursors to rapid light carbon injection at the Palaeocene/Eocene boundary. Nature 450, 1218-1221.

Sluijs, A., Röhl, U., Schouten, S., Brumsack, H.J., Sangiorgi, F., Sinninghe Damste, J.S. Brinkhuis, H., 2008. Arctic late Paleocene-early Eocene paleoenvironments with special emphasis on the Paleocene-Eocene Thermal Maximum (Lomonosov Ridge, Integrated Ocean Drilling Program Expedition 302. Paleoceanography 23. doi:10.1029/2007PA001495.

Speijer, R.P., Morsi, A.M.M., 2002. Ostracode turnover and sea-level changes associated with the Paleocene-Eocene Thermal Maximum. Geology 30, 23-26.

Speijer, R.P., Wagner, R., 2002. Sea-level changes and black shales associated with the late Paleocene Thermal Maximum; organic-geochemical and micropaleontologic evidence from the southern Tethyan margin (Egypt-Israel). In: Koeberl, C., MacLeod, K.G. (Eds.), Catastrophic Events \& Mass Extinctions: Impacts and Beyond. Geological Society of America Special Paper. Geological Society of America, Boulder, pp. 533-549.

Speijer, R.P., van der Zwaan, G.J., Schmitz, B., 1996. The impact of Paleocene/Eocene boundary events on middle neritic benthic foraminiferal assemblages from Egypt. Marine Micropaleontology 28, 99-132.

Speijer, R.P., Schmitz, B., van der Zwaan, G.J., 1997. Benthic foraminiferal extinction and repopulation in response to latest Paleocene Tethyan anoxia. Geology 25, 683-686.

Spring, D., Hansen, O.P., 1998. The influence of platform morphology and sea level on the development of a carbonate sequence: the Harash Formation, Eastern Sirt Basin, Libya. In: Macgregor, D.S., Moody, R.T.J., Clark-Lowes, D.D.(Eds.), Petroleum Geology of North Africa. Geological Society, London, Spec. Publ., vol. 132. London, pp. 335-353.

Stanley, S.M., 2006. Influence of seawater chemistry on biomineralization throughout Phanerozoic time: Paleontological and experimental evidence. Palaegeography, Palaeoclimatology, Palaeoecology 232, 214-236.

Stoll, H.M., Bains, S., 2003. Coccolith $\mathrm{Sr} /$ Ca records of productivity during the PaleoceneEocene Thermal Maximum from the Weddell Sea. Paleoceanography 18, 1049. doi:10.1029/2002PA000875.

Stoll, H.M., Shimizu, N., Archer, D., Ziveri, P., 2007. Coccolithophore productivity response to greenhouse event of the Paleocene-Eocene Thermal Maximum. Earth and Planetary Science Letters 258, 192-206.

Storey, M., Duncan, R.A., Swisher III, C.C., 2007. Paleocene-Eocene Thermal Maximum and the opening of the Northeast Atlantic. Science 316, 587-589.

Svensen, H., Planke, S., Malthe-Sörenssen, A., Jamtveit, B., Myklebust, R., Rasmussen Eldem, R., Rey, S.S., 2004. Release of methane from a volcanic basin as a mechanism for initial Eocene global warming. Nature 429, 542-545.

Tragelehn, H., 1996. Maastricht und Paläozän am Südrand der Nördlichen Kalkalpen (Niederösterreiche, Steiermark) - Fazies, Stratigraphie, Paläogeographie und Fossilführung des "Kambühelkalkes" und assozierter Sedimente. PhD Thesis, Erlangen, 216 pp.

Trenberth, K.E., 1997. The definition of El Niño. Bulletin of the American Meteorological Society $78,2771-2777$.

Terry, C.E., Williams, J.J., 1969. The Idris "A" bioherm and oilfield, Sirte Basin, Libya-its commercial development, regional Palaeocene geologic setting and stratigraphy. In: Hepple, P. (Ed.), The Exploration for Petroleoum in Europe and North Africa. Elsevier, Amsterdam, pp. 31-48.

Thomas, E., 1998. Biogeography of the Late Paleocene benthic foraminiferal extinction. In: Aubry, M.P., Lucas, S., Berggren, W.A. (Eds.), Late Paleocene-Early Eocene Climatic and Biotic Events in the Marine and Terrestrial Records. Columbia University Press, New York, pp. 214-243.

Thomas, E., 2007. Cenozoic mass extinctions in the deep sea: what perturbs the largest habitat on Earth? In: Monechi, S., Coccioni, R., Rampino, M.R. (Eds.), Large Ecosystem Perturbations: Causes and Consequences. The Geological Society of America Special Paper, vol. 424, pp.1-24.

Thomas, D.J., Bralower, T.J., 2005. Sedimentary trace element constraints on the role of North Atlantic Igneous Province volcanism in late Paleocene-early Eocene environmental change. Marine Geology 217, 233-254.

Thomas, E., Zachos, J.C., Bralower, T.J., 2000. Deep-sea environments on a warm earth: latest Paleocene-early Eocene. In: Huber, B.T., MacLeod, K.G., Wing, S.L. (Eds.), Warm Climates in Earth History. Cambridge University Press, Cambridge, pp. 132-160.

Thomas, D.J., Zachos, J.C., Bralower, T.J., Thomas, E., Bohaty, S., 2002. Warming the fuel for the fire: evidence for the thermal dissociation of methane hydrate during the Paleocene-Eocene Thermal Maximum. Geology 30, 1067-1070.

Thompson, E.I., Schmitz, B., 1997. Barium and the late Paleocene $d{ }^{13} \mathrm{C}$ maximum: evidence of increased marine surface productivity. Paleoceanography $12,239-254$.

Trappe, J., 1991. Stratigraphy, facies distribution and paleogeography of the marine Paleogene from the Western High Atlas, Morocco. Neues Jahrbuch für Geologie und Paläontologie-Abhandlungen 180, 279-321.

Trappe, J., 1992. Microfacies zonation and spatial evolution of a carbonate ramp: marginal Moroccan phosphate sea during the Paleogene. Geologische Rundschau 81, 105-126.

Tripati, A., Elderfield, H., 2004. Abrupt hydrographic changes in the equatorial Pacific and subtropical Atlantic from foraminiferal $\mathrm{Mg} / \mathrm{Ca}$ indicate greenhouse origin for 
the Thermal Maximum at the Paleocene-Eocene boundary. Geochemistry Geophysics Geosystems 5, Q02006. doi:10.1029/2003GC000631.

Tripati, A.K., Delaney, M.L., Zachos, J.C., Anderson, L.D., Kelly, D.C., Elderfield, H., 2003. Tropical sea-surface temperature reconstruction for the early Paleogene using $\mathrm{Mg} / \mathrm{Ca}$ ratios of planktonic foraminifera. Paleoceanography 18, 1101. doi:10.1029/2003PA000937.

Turnsek, D., Drobne, K., 1998. Paleocene corals from the northern Adriatic Platform. In: Hottinger, L., Drobne, K. (Eds.), Paleogene Shallow Benthos of the Tethys 2. Dela-Opera SAZU 4. Razprave. Slovenian Academy of Science and Arts, Ljubljana, pp. 129-154.

Turnsek, D., Kosir, A., 2004. Bacarella vipavica n. gen., n. sp. (Anthozoa, Scleractina) from reefal blocks in lower Eocene carbonate megabeds in the Vipava Valley (SW Slovenia). Razprave 45, 145-169.

Vecsei, A., Moussavian, E., 1997. Paleocene reefs on the Maiella platform margin, Italy: an example of the effects of the Cretaceous/Tertiary boundary events on reefs and carbonate platforms. Facies 36, 123-140.

Vlahovic, I., Tisljar, J., Velic, I., Maticec, D., 2005. Evolution of the Adriatic carbonate platform: palaeogeography, main events and depositional dynamics. Palaegeography, Palaeoclimatology, Palaeoecology 220, 333-360.

Wallace, C.C., Rosen, B.R., 2006. Diverse staghorn corals (Acropora) in high-latitude Eocene assemblages: implications for the evolution of modern diversity patterns of reef corals. Proceedings of the Royal Society B 273, 975-982.

Wan, X.Q., Jansa, L.F., Sarti, M., 2002. Cretaceous and Paleogene boundary strata in southern Tibet and their implication for the India-Eurasia collision. Lethaia 35, 131-146.

Weijers, J.W.H., Schouten, S., Sluijs, A., Brinkhuis, H., Sinninghe Damste, J.S., 2007. Warm arctic continents during the Palaeocene-Eocene Thermal Maximum. Earth and Planetary Science Letters 261, 230-238.

Wielandt, U., 1996. Benthic foraminiferal paleoecology and microfacies investigations of Paleogene sediments from the Farafra Oasis, Western Desert, Egypt. Tübinger Mikropaläontologische Mitteilungen 13,1-78.

Wilf, P., Cuneo, N.R., Johnson, K.R., Hicks, J.F., Wing, S.L., Obradovich, J.D., 2003. High plant diversity in Eocene South America: evidence from Patagonia. Science 300, 122-125.

Wilkinson, C.R., 1999. Global and local threats to coral reef functioning and existance: review and predictions. Marine Freshwater Research 50, 867-878.

Willems, H., 1993. Sedimentary history of the Tethys Himalaya continental shelf in South Tibet (Gamba, Tingri) during Upper Cretaceous and Lower Tertiary (Xizang Autonomous Region, PR China). In: Willems, H. (Ed.), Geoscientific Investigations in the Tethyan Himalayas. Berichte aus dem Fachbereich Geowissenschaften. Fachbereich Geowissenschaften, Uni Bremen, pp. 49-183.

Willems, H., Zhang, B., 1993a. Cretaceous and Lower Tertiary sediments of the Tibetian Tethys Himalaya in the area of Gamba (South Tibet, PR China). In: Willems, H. (Ed.), Geoscientific Investigations in the Tethyan Himalayas. Berichte aus dem Fachbereich Geowissenschaften. Fachbereich Geowissenschaften, Uni Bremen, pp. 3-27.

Willems, H., Zhang, B., 1993b. Cretaceous and Lower Tertiary sediments of the Tibetian Tethys Himalaya in the area of Tingri (South Tibet, PR China). In: Willems, H. (Ed.), Geoscientific Investigations in the Tethyan Himalayas. Berichte aus dem Fachbereich Geowissenschaften. Fachbereich Geowissenschaften, Uni Bremen, pp. 29-47.

Willems, H., Zhou, Z., Zhang, B., Gräfe, K.U., 1996. Stratigraphy of the upper Cretaceous and lower Tertiary strata in the Tethyan Himalayas of Tibet (Tingri area, China). Geologische Rundschau 85, 723-754.

Wilson, P.A., Jenkyns, H.C., Elderfield, H., Larson, R.L., 1998. The paradox of drowned carbonate platforms and the origin of Cretaceous Pacific guyots. Nature 392, 889-894.

Wing, S.L., Harrington, G.J., Smith, F.A., Bloch, J.I., Boyer, D.M., Freeman, K.H., 2005. Transient floral change and rapid global warming at the Paleocene-Eocene boundary. Science 310 993-996.
Yeh, S.W., Park, Y.G., Kirtman, B.P., 2006. ENSO amplitude changes in climate change commitment to atmospheric $\mathrm{CO}_{2}$ doubling. Geophysical Research Letters 33 . doi:10.1029/2005GL0256532006.

Zachos, J.C., 1994. Evolution of early Cenozoic marine temperatures. Paleoceanography 9, 353-387.

Zachos, J.C., Lohmann, K.C., Walker, J.C.G., Wise, S.W., 1993. Abrupt climate changes and transient climates during the Paleogene; a marine perspective. Journal of Geology 101 191-213.

Zachos, J., Pagani, M., Sloan, L., Thomas, E., Billups, K., 2001. Trends, rhythms, and aberrations in global climate 65 Ma to present. Science 292, 686-693.

Zachos, J.C., Wara, M.W., Bohaty, S., Delaney, M.L., Petrizzo, M.R., Brill, A., Bralower, T.J. Premoli-Silva, I., 2003. A transient rise in tropical sea surface temperature during the Paleocene-Eocene Thermal Maximum. Science 302, 1551-1554.

Zachos, J.C., Röhl, U., Schellenberg, S.A., Sluijs, A., Hodell, D.A., Kelly, D.C., Thomas, E. Nicolo, M., Raffi, I., Lourens, L.J., McCarren, H., Kroon, D., 2005. Rapid acidification of the ocean during the Paleocene-Eocene Thermal Maximum. Science 308, 1611-1615.

Zachos, J.C., Schouten, S., Bohaty, S., Quattlebaum, T., Sluijs, A., Brinkhuis, H., Gibbs, S.J. Bralower, T.J., 2006. Extreme warming of mid-latitude coastal ocean during the Paleocene-Eocene Thermal Maximum: inferences from TEX $_{86}$ and isotope data. Geology 34, 737-740.

Zachos, J.C., Bohaty, S.M., John, C.M., McCarren, H., Kelly, D.C., Nielsen, T., 2007. The Palaeocene-Eocene carbon isotope excursion: constraints from individual shel planktonic foraminifer records. Philosophical Transactions of the Royal Society A 365 1829-1842.

Zachos, J.C., Dickens, G.R., Zeebe, R.E., 2008. An early Cenozoic perspective on greenhouse warming and carbon-cycle dynamics. Nature 451, 279-283.

Zaier, A., Beji-Sassi, A., Sassi, S., Moody, R.T.J., 1998. Basin evolution and deposition during the Early Paleogene in Tunisia. In: Macgregor, D.S., Moody, R.T.J., ClarkLowes, D.D. (Eds.), Petroleum Geology of North Africa. . Geological Society, London, Spec. Publ., vol. 132. London, pp. 375-393.

Zamagni, J., Mutti, M., Kosir, A., 2008. Evolution of shallow benthic communities during the Late Paleocene-earliest Eocene transition in the Northern Tethys (SW Slovenia). Facies 54, 25-43.

Zhou, Z., Willems, H., Zhang, B., 1997. Marine Cretaceous-Paleogene biofacies and ichnofacies in southern Tibet, China, and their sedimentary significance. Marine Micropaleontology 32, 3-29.

\section{References for Figs. 2 and 3}

Aubry, M.P., Cramer, B.S., Miller, K.G., Wright, J.D., Kent, D.V., Olsson, R.K., 2000. Late Paleocene event chronology: unconformities, not diachrony. Bulletin de la Societé géologique de France 171, 367-378.

Berggren, W.A., Miller, K.G., 1989. Cenozoic bathyal and abyssal calcareous benthic foraminiferal zonation. Micropaleontology 35, 308-320.

Berggren, W.A., Aubry, M.P., van Fossen, M., Kent, D.V., Norris, R.D., Quillévéré, F., 2000 Integrated Paleocene calcareous plankton magnetobiochronology and stable isotope stratigraphy: DSDP Site 384 (NW Atlantic Ocean). Palaeogeography, Palaeoclimatology, Palaeoecology 159, 1-51.

Martini, E., 1971. Standard Tertiary and Quaternary calcareous nannoplankton zonation. In: Farinacci, A. (Ed.), Proceedings of the II Plankton Conference, Roma. Edizioni Tecnoscienza Rome, pp. 739-785.

Okada, H., Bukry, D., 1980. Supplementary modification and introduction of code numbers to the low-latitude coccolith biostratigraphic zonation (Bukry, 1973; 1975). Marine Micropaleontology 5, 321-325. 